Portland State University

PDXScholar

Dissertations and Theses

Dissertations and Theses

1977

\title{
In their hearts forever : the dynamics of Stalinism
}

James Seymour Wilson

Portland State University

Follow this and additional works at: https://pdxscholar.library.pdx.edu/open_access_etds

Part of the European History Commons, Political History Commons, and the Soviet and Post-Soviet Studies Commons

Let us know how access to this document benefits you.

\section{Recommended Citation}

Wilson, James Seymour, "In their hearts forever : the dynamics of Stalinism" (1977). Dissertations and Theses. Paper 2870.

https://doi.org/10.15760/etd.2864

This Thesis is brought to you for free and open access. It has been accepted for inclusion in Dissertations and Theses by an authorized administrator of PDXScholar. Please contact us if we can make this document more accessible: pdxscholar@pdx.edu. 
AN ABSTRACT OF THE THESIS OF James Seymour Wilson for the Master of Arts in History presented February 21, 1977.

Title: In Their Hearts Forever: The Dynamics of Stalinism.

APPROVED BY THE MEMBERS OF THE THESIS COMMITTEE:

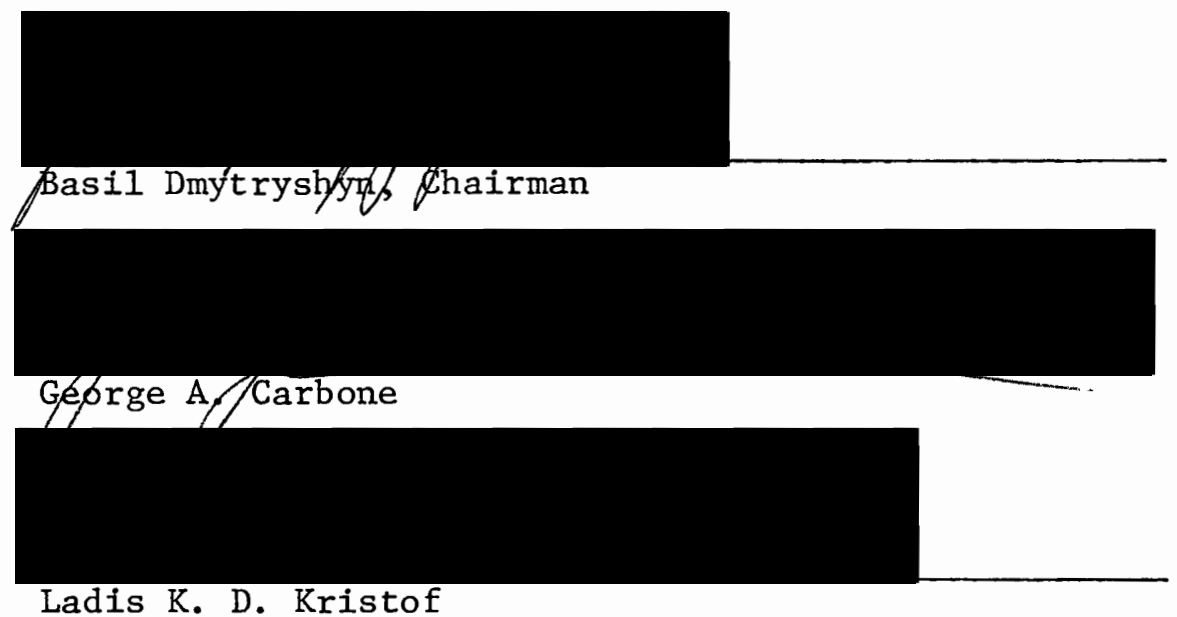

This thesis is a general examination of the Soviet and East European crisis which followed the death of Joseph Stalin in March, 1953. Stalin's character, position, and power were such that the methods he employed in the government of the vast multi-national and multi-state empire bequeathed to his successors could not be made to function in his absence without reform and redefinition. The post-Stalin leadership realized that in order to consolidate its position at the head of the empire a careful program of "de-Stalinization" was mandatory. The prosecution of that program from the announcement of collective 
leadership in April, 1953, to the 1957 Moscow celebration of the fortieth anniversary of the Bolshevik Revolution and the upheavals associated with the period comprise the four year long Soviet and East European crisis of de-Stalinization.

There can be little doubt that the crisis was genuine. The violent convulsions of 1953 and 1956 belie an imperial system only marginally, however finally, under control. Though the stability of the bloc was re-enforced through a single-minded and determined application of force and ideology many other complex factors were involved. Major reforms in all aspects of intra-bloc relations were carried out. The system moved from one governed by diktat enforced by military power to one governed by policy management grounded upon a Soviet military and economic predominance. This study is primarily concerned with the broad conditions and decisions made in the Soviet and East European system between March, 1953, and November, 1957. The general, topical treatment seeks to identify the major pressures and currents in the flow of events, rather than to isolate any one factor and subject it to exhaustive analysis.

Because the treatment is general, the sources consulted were general except where the realistic demands of exposition necessitated more detailed research. Thus the more relevant of Stalin's and Khrushchev's speeches and various other documents have been treated directly, while "secondary" sources have provided the bulk of the research material.

The image of the Soviet and East European system which emerges from this study is one of fundamental, long-range continuity glossed 
over and frequently hidden by more transient change. This is not to say that major changes did not occur, but that they did so within the context of and were assisted by a more profound stability. Though it had been redefined, reformed, and its rhetoric recast, Stalinism, defined as the systematic codification and application of Leninism, remained in force.

This is, therefore, a study of the dynamics and continuities of Stalinism. 
IN THEIR HEARTS FOREVER: THE DYNAMICS

OF STALINISM

\author{
by \\ JAMES SEYMOUR WIISON
}

A thesis submitted in partial fulfillment of the requirements for the degree of

\author{
MASTER OF ARTS \\ in \\ HISTORY
}

Portland State University

1977 
TO THE OFFICE OF GRADUATE STUDIES AND RESEARCH:

The members of the Committee approve the thesis of

James Seymour Wilson presented February 21, 1977.

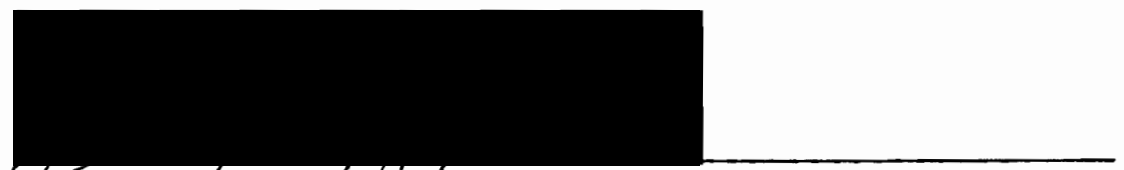

pasil Dmytrysh fon Ghairman

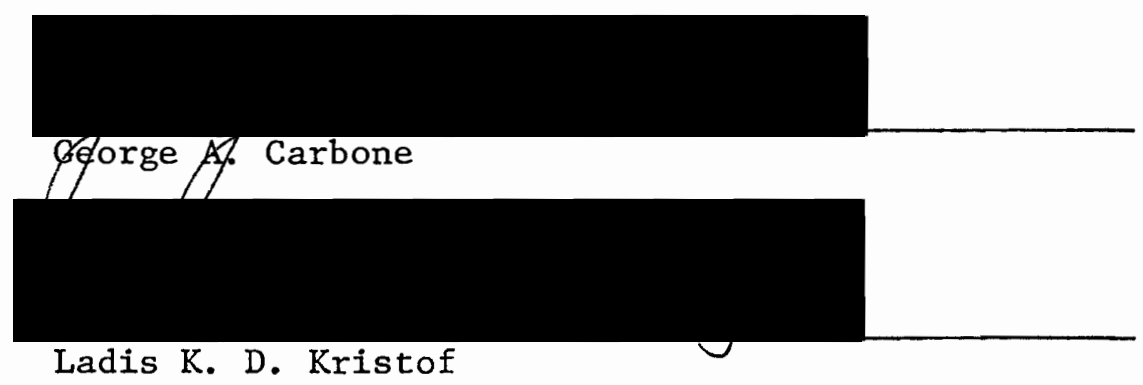

APPROVED:

Michael Reardon, Head, Department of History

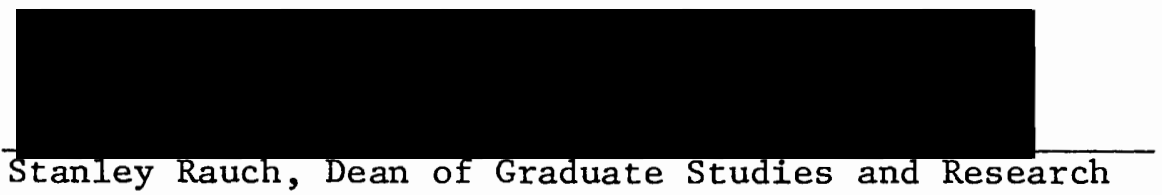




\section{ACKNOWLEDGEMENTS}

I would like to take this opportunity to thank the members of my committee for their help and guidance in the preparation of this thesis and for their patience with the foibles of its preparation.

I. would also like to thank my wife. Without her encouragement and aid it is doubtful that this work would have been completed. 
TABLE OF CONTENTS

PAGE

ACKNOWLEDGMENTS . . . . . . . . . . . . . . . . . . .

INTRODUCTION

CHAPTER

1 THE FOUNDATION OF THE SOVIET BLOC . . . . . . . . . 6

The Aftermath . . . . . . . . . . 6

Foreign Policy Objectives ........... 8

The Expansion Into Eastern Europe . . . . . . 12

The Bases of Control . . . . . . . . . 16

II EXTRASOVEREIGNTY CONTROLS . . . . . . . . . . . 25

The Semiautomatic Controls . . . . . . 25

The Directed Controls . . . . . . . . 29

Institutional Replication ........... 31

III INTERSOVEREIGNTY CONTROLS . . . . . . . . . . . 39

Economic Integration ........... 39

Collective Security . . . . . . . . . 50

IV THE STRENGTHS AND WEAKNESSES OF STALINISM . . . . . . 60

Strengths ................ 60

Weaknesses .............. 63

The Imperatives of Change... . . . . . 68 
V THE NEW COURSE . . . . . . . . . . .

The Objectives........... 74

The Policies and Scope......... 76

An Assessment ............ 80

The Sources of Failure . . . . . . . . 82

The Results ............ . . 85

VI THE SOVIET REASSERTION . . . . . . . . . . 92

The Objectives Recast .......... 92

The Methods . . . . . . . . . . 94

The Regularization of Stalinism . . . . . 95

Economic Reform and Integration ...... 96

The Foundations of the Warsaw Pact . . . . . 102

VII THE RAPPROCHEMENT WITH TITO: THE FIRST ERROR . . . 113

The Purposes of Rapprochement́ ....... 113

The Original Conflict . . . . . . . 114

Reconciliation ........... 116

The Second Denunciation ......... 119

The Influence of Yugoslavia . . . . . . 121

VIII THE SECRET SPEECH: THE SECOND ERROR . . . . . . . 127

IX THE OCTOBER-NOVEMBER CRISIS . . . . . . . . 134

The Polish Crisis . . . . . . . . 135

The Hungarian Crisis . . . . . . . . 139

X THE NEW LENINISM . . . . . . . . . . . . 148

Comparisons ............. 148 
Reconstruction . . ........... 151

XI INTEGRATION . . . . . . . . . . . . . 161

Economics . . . . . . . . . . . . 161

Collective Security . . . . . . . . 163

XII THE DYNAMICS OF CONTINUITY . . . . . . . . . 168

Continuities ............. 168

Dynamics. . . . . . . . . . . . 178

Conclusions . . . . . . . . . . . . 187

BIBLIOGRAPHY . • . . . . . . . . . . . . . . 193

APPENDICES :

A AGREEMENT BETWEEN POLAND AND THE SOVIET UNION, 30 JULY 1941 . . . . . . . . . . . 198

B AGREEMENT REGARDING FRIENDSHIP, MUTUAL ASSISTANCE AND POST-WAR COOPERATION BETWEEN THE SOVIET UNION AND THE POLISH REPUBLIC, MOSCOW, 21 APRIL 1945 . . . . . . . . . . 200

C TREATY OF FRIENDSHIP AND MUTUAL ASSISTANCE AND POST-WAR COOPERATION BETWEEN THE SOVIET UNION AND CZECHOSLOVAKIA, MOSCOW, 12 DECEMBER 1943.

D INDICES OF MAJOR CROP PRODUCTION IN THE BLOC 1948-1955................ . . 209

E PERCENT OF AGRICULTURAL LAND IN THE SOCIALIST SECTOR . . . . . . . . . . . . . 210

F BLOC STATES' FOREIGN TRADE WITH THE USSR AND OTHER BLOC STATES AS A PERCENTAGE OF TOTAL FOREIGN TRADE . . . . . . . . . . 211

G NETWORK OF LONG-TERM TRADE AGREEMENTS CONCLUDED BETWEEN COMECON MEMBERS IN 1950-1951 • . . . 212

H COMECON'S FOUNDING COMMUNIOUE . . . . . . . . 213 THE COMECON CHARTER . . . . . . . . 215 
CHAPTER

PAGE

APPENDICES :

I BLOC TRADE WITH THE U.S.A. AND WESTERN EUROPE

AND EUROPEAN NEUTRAL STATES . . . . . . . . 224

J GENERAI BLOC TRADING PATTERNS, 1937-1952 . . . . 225

$\mathrm{K}$ TREATY OF FRIENDSHIP, COLLABORATION AND MUTUAL ASSISTANCE BETWEEN THE RUMANIAN PEOPLE'S REPUBLIC AND THE SOVIET UNION, MOSCOW, 4 FEBRUARY 1948 . . . . . . . . . . 227

L PERCENTAGE INCREASES IN INDUSTRIAL OUTPUT, 1951-1955 . . . . . . • . . . . . . . 230

M TREATY OF FRIENDSHIP, COOPERATION AND MUTUAL ASSISTANCE BETWEEN ALBANIA, BULGARIA, HUNGARY, THE GERMAN DEMOCRATIC REPUBLIC, POLAND, RUMANIA, THE SOVIET UNION AND CZECHOSLOVAKIA [WARSAW PACT], WARSAW, 14 MAY 1955 . . . . 231

N DECLARATION BY THE GOVERNMENT OF THE USSR ON THE PRINCIPLES OF DEVELOPMENT AND FURTHER STRENGTHENING OF FRIENDSHIP AND COOPERATION BETWEEN THE SOVIET UNION AND OTHER SOCIALIST STATES, OCTOBER 30, 1956 . . . . . . . . 237

O THE REAFFIRMATION OF INTERNATIONAL COMMUNIST SOLIDARITY . . . . . . . . . . . . 243

P STAGES OF COMECON ECONOMIC INTEGRATION . . . . . 248 


\section{INTRODUCTION}

\section{ON THE PROBLEMS OF SCOPE, METHOD, AND PURPOSE}

Since the early nineteenth century, industrialization has become a question of geopolitical Iife and death. Economic development is the central imperative of modern national existence. At issue is not whether a state will industrialize but the method to be used. The vital appeal of Communism is its formal commitment to industrial development.

However, as the industrial development of a given Communist state progresses, a point is usually reached at which Communist ideology, the force which broke through the previous constraints and was able to impel and compel economic development, becomes itself a constraint upon further development. At this point exclusively political and ideological requirements can no longer produce economic growth, and the classic economic madels of Marxism-Leninism lose their fundamental relationship to economic reality and policy. Industrial growth stagnates as indicated and symbolized by dramatically rising capital-output ratios. Political solutions prove impotent for purposes other than the immediate retention of power. In most instances, the bases of economic policy shift from purely political to economic considerations: The Party's ultimate political monopoly is maintained; it is the dictatorship of the proletariat and the concretion of its ideology. 
It was not until the early 1960 s that East European economic reforms attempted to reach beyond the political confines of Stalinism. In the late 1940s, the system which Stalin had developed during the previous decade was transferred to Eastern Europe where it served as the foundation of East European "socialist reconstruction" and as a central element of Communist political power. Since the middle 1950s, however, the various Party leaderships have realized that reforms have been necessary. To the extent that the proposed reforms jeopardized the Parties' political monopoly, they were disallowed; to the extent that they enhanced the Parties' position, they were adopted. The events which forced that realization upon the East European and Soviet Parties can be termed the crisis of de-Stalinization. The process of de-Stalinization began shortly after Stalin's death in March, 1953, and continued in one form or another until approximately 1964. The crisis of de-Stalinization, on the other hand, also began in mid-1953 but lasted only until late 1957. The focus of the present analysis is this four-year crisis and the efforts of the various postStalin leaderships to perform the redefinitions of the Soviet and East European system necessitated by Stalin's death. Within that context, the primary purpose here is to examine those factors which enabled the Soviet Union to weather the crisis and re-establish itself at the head of the bloc late in 1957. This is, therefore, a study of the continuities of Soviet power in Eastern Europe up to the end of 1957. That the crisis of de-Stalinization was real there can be little doubt. The convulsions of 1953 and 1956 exemplify a system only marginally, though finally, in control. The resolutions of the conflicts 
which led to those events demonstrated that Soviet military power alone could not enforce a favorable solution to the underlying crisis. A "Carthagenian" solution, the Soviets realized, would have produced further destruction and at a counterproductive cost. The military answer could be used only in the most extreme Hungarian case. Even there, the enforced retention of a Communist government was accompanied over the years by economic and political reforms. In Poland, Gomulka was clearly threatened with Soviet force but promised armed resistance to direct Soviet military intervention. The "Polish solution" involved the threat of force but also economic and political reforms both with in Poland and in Poland's relations with the Soviet Union. Though the stability of the bloc was restored through the direct application of force in Hungary, and therefore the implied threat of its use elsewhere, and limited economic and political reforms, many other factors were also involved: the functional absence of concrete Western aid; the ability of most East European Parties to maintain political control; the interests of those Parties served by the centralist position of the Soviet Union and the Communist Party of the Soviet Union (CPSU); the security provided by close relations with the Soviets against the threat of future German aggression, a threat which was very real in the minds of many East Europeans; and the Communist commitment to industrialization. It is these factors, military, political, and most importantly, economic, which in their interaction comprise the dynamics of Stalinism: the basis for the continuity of Soviet power in Eastern Europe.

The image of the Soviet and East European system which emerges from this study is one of long-range continuity partially obscured by 
more superficial changes. This is not to say that important changes did not occur, but that they took place within the context of a more fundamental stability. For example, the bilateral treaty network, which formed the legal basis of the Soviet and East European collective security system, was replaced in 1955 by the Warsaw Pact. This was a shift from a bilateral to a multi-lateral form, but the substance of the Soviet and East European collective security system remained. This situation was roughly paralleled in other areas. As of 1957, the fundamental elements of Soviet hegemony in Eastern Europe were intact. The Stalinist economic system, despite some relaxations in agriculture, the political monopoly of the bloc's Communist parties, the primacy of the CPSU, the economic primacy of the Soviet Union, the commitment to world Communist revolution, and the essential commitment to industrialization--all remained in place. Though it had been redefined, operationally reformed, and its rhetoric recast, Stalinism, as defined as the systematic codification and application of Leninism, continued in operation.

Therefore, this study is concerned with the broad conditions and major decisions made in the Soviet and East European system between the last stages of the Second World War and the 1957 Moscow celebration of the fortieth anniversary of the Bolshevik Revolution. The treatment is general and topical. It seeks to identify pressures and currents rather than isolate one given factor and subject it to exhaustive analysis. Because the scope is general, the sources used are also general. No attempt has been made to research beyond general works except where the realistic requirements of balance and clarity necessitated. 
To an extent, every piece of analysis, every research project, is both a success and a failure. Its achievements are mitigated by the Iimitations of the researcher, the scope of the enquiry, and the methods of analysis employed. Guarded by qualifications, its tentative conclusions stand as open questions rather than as final answers. This work is no exception and does not pretend to be. Therein lies its chance of success. 
CHAPTER I

THE FOUNDATION OF THE SOVIET BLOC

"Those last years with
Stalin were hard times." -- Khrushchev1

THE AFTERMATH

It was announced on March 6, 1953. "The heart of Lenin's comradein-arms, the standard bearer of his genius and his cause, the wise leader and teacher of the Communist Party and the Soviet Union, has ceased to beat." 2 The "brilliant continuator," the "indefatigable builder of Communism," the "Great Stalin" was dead. The nation wept and the Party trembled. The epoch was finished.

It has been speculated that the situation the new Soviet leadership faced appeared to them as both bizarre and threatening. On the one hand, it was possible that the struggle between the Party's factions for power would threaten the achievements of the Stalin era. 3 on the other hand, Stalin's absence would allow needed innovations in the methods used in the pursuit of Soviet goals. 4 Reform had become vital. In April, 1953, the East Germans requested economic assistance and a reconsideration of the Stalinist capital-development program. ${ }^{5}$ The East German regime was In serious danger. Albania immediately after Stalin's death dropped its 1951-1955 economic plan. 6

The Soviet leadership (Georgi M. Malenkov, Stalin's designated 
successor and the new Chairman of the Council of Ministers; Lavrentii P. Beria, the chief of the Soviet security forces and First Deputy Chairman of the Council of Ministers; Viacheslav M. Molotov, a Bolshevik since 1906 and diplomat in charge of foreign policy from 1939 to 1949 and again following Stalin's death; Nikolai A. Bulganin, a long-time Bolshevik and government functionary who was Minister of Defense from 1947 to 1949 and again from 1953 to 1955; and Nikita S. Khrushchev, Stalin's deputy in the Ukraine during the purges of the 1930s and following the war and head of the Moscow Party organization from 1949 to 1953 when he became First Secretary of the CPSU) soon realized that Stalin's immediate methods would not work without Stalin. Therefore, a rapid and prudent course of de-Stalinization was essential. 7 The first explicit move in that direction was taken in the form of an April, 1953, Pravda article, entitled "Collectivity is the Highest Principle of Party Leadership." The article argued that all important decisions are the fruit of collective decisions. In the collective process, mutual and self-criticism are important to prevent error and are based upon "collectivity." However, individual responsibility must not be lost. Collective leadership is necessary for the initiative of Party organizations and the self-reliance of their members. The article concluded with the assertion that collective leadership is a necessity in the building of Communism. 8

The first faction to pose a threat to the Soviet collective leadership was headed by Beria. He was the first to move. Long before Stalin's death, Beria had begun building up his position. Indeed, Beria's strength even before Stalin's death was such that Khrushchev 
felt Stalin feared Beria. Khrushchev also knew that it would be necessary following Stalin's death to ensure that Beria did not hold power. 9 From his position as the second man in the hierarchy within the collective leadership, Beria made a two-pronged bid for power. He consolidated his hold on the secret police and made a play for public popularity. His power bid failed. It was subsequently announced on July 10, 1953, that Beria had been "unmasked." He and several of his associates were tried the following December and immediately shot. 10

Thus ended the era of Stalin. It was "an era of tyranny which in its cruelty and personal concentration of power stands without precedent in modern history." 11

\section{FOREIGN POLICY OBJECTIVES}

The empire the leadership inherited from Stalin and which they had helped to build was based upon Soviet geopolitical realities, Stalin's application of Leninism to the Soviet Union, and the extension by force of that system into new territories as a consequence of the Second World War. The Soviet Union emerged from that war as what would come to be known as a super power, a position secured by the Soviet development of an atomic bomb in 1949 .

The Second World War shattered the European balance of power and left the Soviet Union in occupation of the traditional Central and East European "buffer zone." Little stood between the Soviet military machine and Europe's Atlantic coast.12 Germany had been divided; Japan had been reduced to its main islands; Italy had been shorn of its 
colonial possessions; and in general other Western colonial possessions were in the process of being relinquished. In contrast, the Soviet Union had directly annexed some 250,000 square miles of territory, established satellite or client states in Europe and Asia, and stood ready to fill any political or military vacuum which might develop in the immediate postwar turmoil. 13

Specifically, the annexed territories were the Tannu-Tuva Republic which had been a part of Mongolia, Southern Sakhalin and the Kurile Islands in the Far East, the Carpatho-Ukraine taken from Czechoslovakia, various areas from Finland, Latvia, Lithuania, Estonia, Eastern Poland, Bessarabia, Northern Bukovina, and the northern half of East Prussia.14 The long term East European satellite states have proven to be: Poland, East Germany, Czechoslovakia, Hungary, Rumania, and Bulgaria. In terms of population, the Lithuanian, Moldavian, Latvian, Estonian, and other minorities which were not a part of the Soviet Union at the time of the 1939 census comprised in 1959 some 14,144,000 out of a total Soviet. population of $208,827,000$ or 6.9 percent. 15

However, Soviet losses as a result of the war were also vast. Some 20,000,000 persons had been killed and the industrial plant had been shattered.16 However, by 1950 the Soviet Union had largely reconstructed its economic losses.17 Thus, contrary to their expectations, Stalin and those around him found that the state which they controlled possessed an overwhelming strength vis-a-vis the rest of Europe. The non-Communist political forces in Eastern Europe were weak; Western Europe and the United States were demobilizing rapidly, leaving a power vacuum.18 In those happy circumstances the Soviet Union intended 
to "enjoy all the prerogatives" of its new position.19

Soviet postwar foreign policy objectives can be grouped as geopolitical and intrabloc. 20 Geopolitically, the maximum Soviet goal has been considered by many scholars to be the "revolutionary conquest of the world" and the active, as opposed to passive, defense of the Soviet Union, the "heartland of Communism."2l The World War II Teheran, Yalta, and Potsdam agreements supported the Soviet claim to the creation of governments in Eastern Europe which were "democratic and friendly" to the Soviet Union. 22 At Yalta, the Soviet Union sought its post-war security through the complete dominance of Eastern Europe and a preponderant influence in the rest of Europe itself. 23 The Potsdam agreements in their turn emerged as a confirmation of the Yalta agreements both through explicit agreement and Western inaction. 24

Stalin's "election speech" given on February 9, 1946, established as an element of Communist ideology that one of the major results of the Second World War was the proof that the Soviet system was more enduring than and inherently superior to any non-Soviet social system. 25 Further, in his speech to the 19th Party Congress given on October 17, 1952, Stalin asserted that the interests of the Soviet Union were "Inseparable from world peace."26 Given the ideology of MarxismLeninism, there can be little doubt that "world peace" was possible in the long run only after the "historically inevitable" destruction of all non-Soviet social systems.

This view of Soviet foreign policy objectives is also supported by published Soviet sources. In History of Soviet Foreign Policy 19451970, a standard Soviet text, A. Alexandrov writes in regard to Soviet 
and East European foreign policy coordination:

United action by the socialist countries in foreign policy is a vital factor in preserving peace and ensuring the progressive development of all mankind. 27

Alexandrov continues:

Socialist international relations spell out not only peace and genuine equality but also fraternal mutual assistance between the free and sovereign peoples of the socialist community, and they soon gave rise to the idea of socialist integration. These relations are the prototype of the relations that will be established in future between all the peoples and countries of the world. 28

In a less ideological direction, it can be argued that at the very least the Soviets were and are determined to expand their sphere of influence to whatever extent possible without running a serious risk of global war. 29

The simplest and most banal explanation is not necessarily wrong; the Soviet Union was bent upon expanding her sphere of power and influence but without incurring the risk of war. 30

The Soviets viewed the postwar situation in Eastern Europe as both an opportunity in the "revolutionary conquest of the world" and as a chance to finally achieve Soviet territorial security in line with the active defense of the "heartland of Communism." Therefore, the "Soviet leaders demanded a safe and secure protective belt of countries unquestionably loyal to themselves to cover their vulnerable Western frontier." 31

Regardless of the specifics of emphasis. Soviet foreign policy in the postwar period was expansionist. The vast territories added directly to the Soviet Union and those brought under Soviet hegemony were not acquired accidentally. 
By 1948, the Soviet Union had completed the basic formation of the East European bloc. Zbigniew Brzezinski, in his classic work, The Soviet Bloc: Unity and Conflict, has cited the following Soviet objectives in Eastern Europe: to deny the area to Germany or any other power; to ensure that the individual East European countries would not be controlled by domestic elements hostile to the Soviet Union; to use Eastern Europe as a buffer against Germany or any other power; to ensure that the individual East European countries would not be controlled by domestic elements hostile to the Soviet Union; to use Eastern Europe as a buffer against Germany or any other power; to use the area as a capital source; to use the area to aid Soviet economic recovery; to use Eastern Europe as a revolutionary springboard in a revolution which must "go forward," and to use Eastern Eruope as an element in the integration of the "socialist bloc" into an independent geopolitical unit. 32

In the postwar period, therefore, the Soviet Union had two main objectives: to expand wherever and to whatever extent possible and to consolidate and integrate into a single political and economic system the territorial, political, and economic gains which had been or were to be made.

THE EXPANSION INTO EASTERN EUROPE

From the standpoint of continuity with the postwar period, the extension of the Stalinist system into Eastern Europe began in the early stages of the war when the Soviets organized National Liberation Committees for each of the East European countries. 33 As a result of 
the rise of European Fascism in the 1930s, many European Communists had fled to the Soviet Union where most of them fell victim to the purges of the $1930 \mathrm{~s} .34$ However, it was from their surviving ranks that the National Liberation Committees were staffed. 35 The main postwar purpose of these committees was to serve as the core of each of the pro-Soviet governments, with the exception of Yugoslavia, created between 1945 and 1948.36

Though the pattern varied substantially throughout Eastern Europe, the Polish case is a good example. The process began in earnest with the signing of the Nazi-Soviet pact on August 23, 1939, and the additional secret protocol on September 29, 1939. By this agreement, Poland was "divided" along the Vistula River into German and Soviet spheres of influence. After Poland was overwhelmed in September, 1939, the Iine demarking the Nazi and Soviet spheres of influence was redrawn in conformance with the 1793 second partition of Poland. Between late 1939 and June, 1941, the Soviets seemingly had no plans for the creation of a satellite government in the Soviet zone of conquered Poland. They followed instead a policy designed to exterminate all Polish political consciousness. Indeed, the Polish territories were directly incorporated into the appropriate Soviet republics. 37

After the German invasion of the Soviet Union on June 22, 1941 , the situation altered slightly. On the one hand, Stalin sought a rapprochement with the London-based Polish government in exile (see Appendix A for the text of the mutual assistance pact concluded between the two powers); while, on the other hand, Stalin set down the founda- 
tions for the future take-over of Poland by Soviet-sponsored Polish Communists. 38 On March 1, 1943, the Union of Polish Patriots was formally established in Moscow as the "true" representative body of Poland. This was the end result of much careful ground work. By the middle of 1943, the Soviet Union had formed the two instruments of its future policy in Poland: the Union of Polish Patriots and the Polish Workers' Party, a political front organization. 39

Following the defeat of German forces in eastern Poland, on July 21, 1944, in Lublin, Poland, the Union of Polish Patriots was merged with Polish Communist and other groups in the formation of the Polish Committee of National Liberation. On July 26, 1944, the Polish Committee of National Liberation signed an agreement with the Soviets to administer Polish territory occupied by the Soviets in the course of the war. Finally, on December 31, 1944, the Lublin Comittee declared itself to be the provisional government of Poland and was recognized as such by the Soviets on January 5, 1945, the Soviets having broken diplomatic relations with the Polish government in exile in April, 1943. (See Appendix B for the text of the pact concluded.between the Soviet Union and its Lublin government.) One of the results of these maneuvers was that the Polish Workers" Party, the Communist Party of Poland at that time, was deeply divided between those brought from Moscow, the "Muscovites," and those who had fought it out in Poland, the "natives."41 This situation was replicated throughout the sateilite countries and was to prove dangerous for the Soviets as well as the Party factions involved. 
With its Westerm allies, the diplomatic maneuvering involved in the extension of Soviet hegemony began in 1941 and lasted until 1945. The Soviet Union had legitinized its territorial acquisitions and its sponsored East European border changes such as the westward movement of Poland. The Soviets promised that the new East European governments would be established through free elections which would be "responsive to the will of the people." 42

Also, an important pattern was established in Czechoslovakia. As a result of Soviet and Czechoslovak moves, which began with the Soviet offer of aid in September, 1938, the two governments signed a treaty of Friendship, Mutual Assistance and Post-War Collaboration on December 12, 1943.43 (See Appendix C for a text of the SovietCzechoslovak treaty.) The Czechoslovak treaty set the pattern followed in the creation of the bilateral treaty system which formed the legal, that is, formal basis for the Soviet and East European system. 44

Hugh Seton-Watson, a British Sovietologist, has identified three phases in the Communist seizure of power in Eastern Europe. The first stage was that of genuine coalition government which allowed nonCommunist opposition parties freedom of action. In the second stage, bogus coalition governments were formed and the non-Communist parties lost their ability to criticize Communist policies. The third phase abolished or absorbed all non-Communist parties. The East European states passed through these stages at varying rates, some entirely skipping the first or severely trunkating it. By the end of 1948, the Communist East European bloc had emerged. 45 
THE BASES OF CONTROL

The fundamental system of control thus established by Stalin and the Soviet Union was built upon five simple and direct fundamentals: ideology, "socialist international relations," the economic and political primacy of the Soviet Union, the "socialist reconstruction" of Eastern Europe, and the presence of the Soviet Army. Communist orthodoxy in the postwar period was based upon four ideological assumptions. The first was that Communism must by virtue of scientific and historical necessity supersede Capitalism as the dominant method of social and economic organization. The second assumption was that the historical processes generating Capitalism's collapse required purposeful promotion through disciplined organization, direct action, and, of course, class conflict. The third assumption was that social change must be accelerated through rapid socialization and industrialization. This process would also directly aid the destruction of Capitalism by broadening the socialist econemic base. The last assumption was that because of the internal and external threat to the Communist revolution, political power must be exclusively held by the local Communist parties and that these Parties must maintain unity between themselves through the processes of centralized leadership, uniformity of ideology, and an underlying uniformity of action. 46

Socialist international relations within the bloc were categorically not confined to relations between governments. The new international relations in Eastern Europe were to operate on all levels of national life. These relations are described by Alexandrov as follows: 
In the old world the concept 'international relations'

is the equivalent of the concept 'interstate relations.'

It only embraces the system of relations between governments and their agencies. In the case of socialist international relations, they cannot be reduced solely to relations between states; they embrace all aspects of the life of the peoples. The working people themselves --workers, peasants, and working intellectuals of all the socialist countries--take a direct and active part in strengthening the socialist community and, consequently, in implementing the principles of socialist interstate relations. In promoting co-operation in the socialist community, a key role is played by fraternal relations among the Communist and Workers' parties, which adhere to the principles of Marxism-Leninism, and by friendly relations between mass public organizations. 47

Socialist international relations do not exist merely on the governmental level. They exist on each of the definable levels of a state's socioeconomic structure and on a "level to level" basis. The most important of course are government to government and Party to Party relations.

The Soviet Union was presented ideologically in Eastern Europe as being economically and politically of primary importance. As the first socialist state and the ultimate source of the socialist revolution, that which strengthened the Soviet Union strengthened the international Communist movement. If a temporary problem arose due to economic relations which favored the Soviet Union, the damage and difficulties were outweighed by the increased strength of the Soviet Union, world Communism as a whole, and, therefore, of the particular East European state experiencing the damage or difficulty. What made the Soviet Union strong, In the final analysis, according to this circular argument, made the individual East European countries strong. 48

Following Marxist thinking, the "socialist reconstruction" of the East European countries would create, in Brzezinski's words, a "solid, spirited, and single-minded phalanx which would stand together 
under any circumstances." 49 The reconstruction was to work as follows:

The parties, by becoming Stalinized, by purging themselves and destroying such sources of deviationism as the Social Democrats, would tend to be more oriented toward the USSR. Terror used against the population at large would destroy any sources of potential opposition to the régime and introduce such fear that compliance with the policies and purposes of the system would be assured. Collectivization would carry the class struggle into the countryside and weed out the normally conservative orientation of the peasants, driving them into collective institutions where they could be subjected to organized political and economic control. Economic transformation through nationalization and, more significantly, through industrialization, would create the objective basis for socialism while ripping apart the social fabric to such an extent that the Communist Party--Stalinist and dependent on the Soviet Union--would be the only source of social cohesion, the only organization to which the youth, in particular, could turn for guidance. 50

Purges would strengthen and centralize the local Communist parties, terror would silence all possible opposition, collectivization would enable economic and political control of the peasants, socialization and Industrialization would deliver the national economies into the Parties' control and would shatter the existing social patterns to such an extent that only the local Communist party organizations would remain functioning.

Throughout the process, the Soviet Army stood ready to guide events in the desired direction. It was that presence which made the expansion of the Soviet system possible. 51 For example, the Soviet Union concluded an agreement with the Lublin Committee whereby the Committee was assigned the authority to administer Polish territory occupied by the Soviet Army.52 Further, examples of direct Soviet intervention in the postwar period in support of the emerging Communist governments included the arrest of Bela Kovacs, the leader of the 
Hungarian Smallholders' Party, on February 25, 1947.53 Milkolajczyk, the former prime minister of the Polish government in exile, who had been grudgingly included in the postwar Polish Government, fled Poland in fear of his life in November, 1947.54 Indeed, the Soviet Army was directly or indirectly the critical factor in the process of establishing Soviet control; local statesmen faltered under the pressure of Soviet power. 55 In short,

Stalin's successes came where the Soviet Army was in a position to lay a firm foundation for Communist domination, and his failures occurred in areas where the case for Communism had to be put by persuasion, propaganda, and example. 56

As subsequent events were to demonstrate, the Soviet Army was to remain a central element in bloc affairs.

Upon this foundation the Soviet Union constructed a dynamic, interlocking system of control comprised of two definable subsystems: extrasovereignty relations and intersovereignty relations. 
NOTES

CHAPTER I

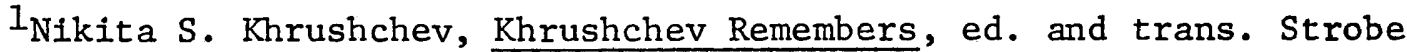
Talbott, annotated by Edward Crankshaw (New York: Bantam Books, 1971), p. 317. The Khrushchev memoir is taken here at face value with the realization that an allowance must be made for the motives which Khrushchev may have had in preparing the original dictation. The view presented by the memoir is through Khrushchev's eyes and memory.

${ }^{2}$ Ibid., p. 340 .

3Adam Ulam, Expansion and Coexistence, 2nd ed. (New York: Praeger, 1974), p. 541 .

${ }^{4}$ Thomas W. Wolfe, Soviet Power and Europe, 1945-1970 (Baltimore: The Johns Hopkins Press, 1970), p. 73. Wolfe is a political scientist, senior staff member of the Rand Corporation, and a frequent government consultant.

5 Zbigniew K. Brzezinski, The Soviet Bloc: Unity and Conflict, rev. ed. (New York: Praeger, 1961), p. 157. Until 1977 Brzezinski was the director of Columbia University's Institute on Communist affairs. He is currently (1977) a member of the Carter Administration.

6Michael Kaser, Comecon: Integration Problems of the Planned Economies (London: Oxford University Press, 1965), p. 19. Kaser is a lecturer on Soviet economics at Oxford.

7Ulam, p. 541.

${ }^{8}$ L. Slepov, "Collectivity is the Highest Principle of Party Leadership," Pravda, April 16, 1953, in The Current Digest of the Soviet Press 5 (March 1953): 3, 30, in Robert V. Daniels, ed., A Documentary History of Communism, 2 vols. (New York: Random House, 1960), vol. 2, pp. 207-210.

${ }^{9}$ Khrushchev, pp. 335-339.

10Ulam, pp. 542-543. For a full list of the official charges against Beria, which range from moral depravity and murder to his having been a British agent since 1919, see "Official Charges Against L. P. Beria and his Associates," Isvestia, December 17, 1953, trans. Basil Dmytryshyn, in 
Basil Dmytryshyn, USSR: A Concise History (New York: Charles Scribner's Sons, 1971), pp. 475-478.

\section{${ }^{11}$ Ibid., p. 539.}

${ }^{12}$ Louis J. Halle, "The Cold War As History," from Louis J. Halle, The Cold War As History (New York: Harper and Row, 1971), in Gordon Wright and Arthur Mejia, eds., An Age of Controversy, alt. ed. (New York: Dodd, Mead and Company, 1972), p. 263.

13Vernon V. Aspaturian, "A Half Century of Soviet Foreign Policy," in Vernon V. Aspaturian, ed., Process and Power in Soviet Foreign Policy (Boston: Little, Brown and Company, 1971), pp. 87-111.

${ }^{14}$ Basil Dmytryshyn, USSR: A Concise History, 2nd ed., (New York: Charles Scribner's Sons, 1971), pp. 238-239. Dmytryshyn is a professor of history at Portland State University. His work, USSR: A Concise History, has emerged as a standard text in the field of Soviet studies. It has been used in this present study primarily as a reliable source for documents, summaries of events and agreements, and as a "concise" outline of major events.

${ }^{15}$ Vernon V. Aspaturian, "Introduction," in Vernon V. Aspaturian, ed., Process and Power in Soviet Foreign Policy (Boston: Little, Brown and Company, 1971), pp. 3-83.

${ }^{16}$ Morton Schwartz, The Foreign Policy of the USSR: Domestic Factors (Encino: Dickenson Publishing Company, 1975), pp. 12 and 23.

17Schwartz, p. 23. For a detailed discussion of Soviet territorial gains and losses and various related economic and geographic factors, see Schwartz, pp. 5-41.

$$
\begin{aligned}
& \text { 18 Brzezinski, p. } 51 . \\
& \text { 19 Ulam, p. } 405 .
\end{aligned}
$$

20 The factors which conditioned the formation of Soviet postwar objectives fall into three groups: ideological, historical, and economic. A treatment of these elements and their interaction is beyond the scope of this work. For excellent discussions of this question, see Morton Schwartz, The Foreign Policy of the USSR: Domestic Factors; Robert G. Wesson, The Russian Dilemma; and Adam Ulam, Expansion and Coexistence.

21 J. M. Mackintosh, Strategy and Tactics of Soviet Foreign Policy (New York: Oxford University Press, 1963), p. I. 
${ }^{22}$ Brzezinski, p. 32 .

23Ulam, pp. 368-377. See also: Charles F. Delzell, "Russian Power in Central-Eastern Europe," in John L. Snell, ed., The Meaning of Yalta (Baton Rouge: Louisiana State University Press, 1956), pp. 75-126; Herbert Feis, Between War and Peace, The Potsdam Conference (Princeton, N. J.: Princeton University Press, 1960); and Diane Shaver Clemens, Yalta (New York: Oxford University Press, 1970).

For example, to the British the question of Poland was a matter of honor, for the United States it was a symbol of allied cooperation; however, for Stalin Poland was a question of Soviet national security. The Soviet interest in Poland was material rather than ideal. (Delzell, p. 120) Also, at Potsdam, Stalin was "humorless, and living within himself, he was a most able, though short-sighted, proponent of the traditional Russian instinct to expand and absorb." (Feis, p. 317)

${ }^{24}$ Ulam, pp. 388-394.

25 J. V. Stalin, "Stalin's 'Election' Speech, February 9, 1946," in Bolshevik, No. 3 (March 1946): 1-11, trans. Dmytryshyn, in Dmytryshyn, pp. 450-459.

${ }^{26} \mathrm{~J}$. V. Stalin, "Stalin's Last Speech," For A Lasting Peace, For A People's Democracy, No. 42 (206), October 17, 1952, p. I in Dmytryshyn, pp. 472-474.

27 A. Alexandrov, et al., History of Soviet Foreign Policy 1945-

1970 (Moscow: Progress Publishers, 1973), pp. 74-75.

${ }^{28}$ Ibid., pp. $76-77$.

${ }^{29}$ Robert G. Wesson, The Russian Dilemma: A Political and Geopolitical

View (New Brunswick: Rutgers University Press, 1974), p. 109.

30U1am, p. 404.

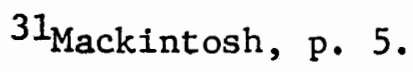

32 Brzezinski, pp. 4-6 and 124 .

33 Dmytryshyn, pp. 239-240.

${ }^{34}$ Anatole Shub, An Empire Loses Hope: The Return of Stalin',s Ghost (New York: W. W. Norton and Company, 1970), p. 47. Shub is primarily a journalist specializing in Soviet and East European topics. 
${ }^{35}$ Dmytryshyn, p. 240.

${ }^{36}$ Ibid.

37M. K. Dziewanowski, The Communist Party of Poland (Cambridge: Harvard University Press, 1959), pp. 157-159.

38 Ibid., pp. 161-162.

${ }^{39}$ Ibid., p. 168.

40 Dmytryshyn, p. 243; Dziewanowski, pp. 166-168 and 176-184. See also Jan Ciechanowski, Defeat in Victory (Garden City: Doubleday and Company, 1947). Ciechanowski was the ambassador of the Polish government in exile during the Second World War. His book presents a vivid account of the diplomatic maneuvering surrounding the "Polish question" during and just after the war.

It was the Soviet refusal to allow an impartial investigation of the Katyn massacre (the execution of Polish officers by the NKVD following the Soviet-German invasion of Poland) which caused the break in relations between the Polish government in exile and the Soviet Union.

${ }^{41}$ Dziewanowski, p. 190.

42 Dmytryshyn, pp. 240-241. See also Edward J. Rozek, Allied Wartime Diplomacy, A Pattern in Poland (New York: John Wiley and Sons, 1958).

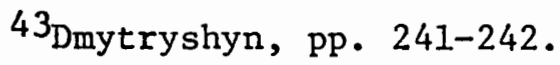

${ }^{44}$ Brzezinski, p. 108.

45 Hugh Seton-Watson, The New Imperialism (Totawa: Rowman and Littlefield, 1971), pp. 81-83. For more complete information see: Hugh Seton-Watson, The East European Revolution, or Nicholas Halasz, In The Shadow of Russia.

46 Brzezinski, p. 395.

${ }^{47}$ Alexandrov, p. 75 .

48 Brzezinski, p. 106.

${ }^{49}$ Ibid., p. 103.

40 Ibid. 
5I Mackintosh, pp. 3-4.

${ }^{52}$ Ibid., p. 6.

53 Mackintosh, p. 9.

54Dziewanowsk1, p. 206.

55 Mackintosh, pp. 30-31.

${ }^{56}$ Ibid., p. 62 .

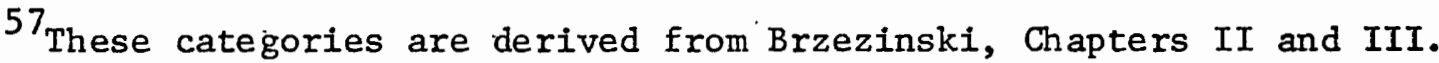




\title{
CHAPTER II
}

\section{EXTRASOVEREIGNTY CONTROLS}

\author{
"You need not doubt that I shall do my \\ best to justify your trust." -- Stalin1
}

\section{THE SEMIAUTOMATIC CONTROLS}

For the purposes of this present analysis, the relations between any two states or within a group of states fall into two general categories: extrasovereignty relations and intersovereignty relations. Extrasovereignty relations are those relations which take place beyond the confines of formal diplomatic channels or which are not directly covered by state to state treaties. Intersovereignty relations are those relations which take place through formal diplomatic channels. The relations between the government of the Soviet Union and, for example, the government of Czechoslovakia would be an example of intersovereignty relations; while the relations between the respective Communist parties would be examples of extrasovereignty relations. For Eastern Europe as a whole during the period concemed "relations" between the Soviet Union and the CPSU and the individual East European governments and Communist parties were such that those relations constituted methods and channels of frequently blatant control.

The extrasovereignty controls of the Soviet Union in Eastern Europe fell into three main categories: semiautomatic control systems, 
directed control systems, and institutional replication.

A semiautomatic control system can be considered to be any method of control which functions with a minimal amount of supervision on the part of the controlling agent. This process is roughly analagous to the concept of "management by exception" in accounting or business administration in which only the exceptional conditions are acted upon by higher authority once the general operational objectives and procedures have been set into motion.

The first of the semiautomatic systems was the reconstruction of the local Communist parties which conducted local governmental administration in the image of the CPSU. ${ }^{3}$ This involved the obligatory glorification of Stalin, the CPSU, and the USSR. The CPSU along with Stalin were promoted via a massive propaganda program as, and to an extent actually considered to be, incapable of any error. The campaign's general aims were to eliminate "negative conceptions of Soviet life" and to "instill a positive emotional commitment to the USSR." In a sense the process worked too well. Between 1949 and 1953 many of the most radical decisions were not made by Stalin, but by local Communist leaders on the basis of their anticipation of Stalin's reaction or wishes. This zealousness was an attempt by the "little Stalins" to do what Stalin might have done. This process and Soviet policies in general led inexorably to the second semiautomatic system.

The radical political and economic programs (harrassment of opposition political parties, extreme labor norms, forced farm collectivization, and various types of press and cultural censorships, for example) imposed by the local Parties upon their countries critically 
increased their domestic unpopularity and at the same time their dependence upon Stalin and the Soviet Union.

Because of his unwillingness to allow Stalin a free hand in Yugoslavia, Tito, the leader of Yugoslav Communism, was expelled from the Cominform on June 28, 1948.4 The paranoid Stalinist reaction to "Titoism," the cause of Tito's expulsion, sent a wave of Party purges through Eastern Europe. The tempo of Sovietization was also stepped up. "Separate ways to socialism became a crime."5 The end result was the creation of Parties and local leaders totally, and some would say, blindly loyal to Stalin.

The third semiautomatic system arose from the territorial shifts resulting from the Second World War. The territorial gains assigned to Poland were, among other things, a "way to guarantee her staying with in the Soviet sphere."6 Generally, the population and border shifts throughout Eastern Europe, though approved by the West, established the Soviet Union as the guarantor of the postwar frontiers. This further increased the dependence of the individual East European states upon the Soviet Union and upon Stalin. 7

The fourth system was the maintenance of a constant atmosphere of crisis. A crisis atmosphere is a virtual necessity to the Soviet political system: the monopoly of political power held by the Party: the "party-police" system of control. 8 Three elements were combined to create the desired popular fear: the danger of "capitalist aggression," the "cold war," and the threat of a revanchist Germany. Unity and discipline were touted as necessary in the face of the "outside" threat. 9 The fifth semiautomatic system was and is more profound. By 
1949 or 1950, the results of the "socialist reconstruction" had served to preclude any anti-Communist resistance. The Church, generally a last focus of opposition, was reduced to a "sanctuary" for alternative values. In this period, it could not be a source of active opposition. Further, until 1951 or 1952, the Communist emphasis upon the future, a future which contrasted sharply with the stark brutality of the immediate past and the equally stark present, had broad popular appeal. The uncertainty of the immediate postwar era bred a craving for certainty. Only the Communist movement offered or was permitted to offer both a future and certainty. "Thus even the unbelieving were brought face to face with the dilemma of the one alternative-to oppose Communism was to be against everything and for nothing."10

The "dilemma of the one alternative" is, however, also the most effective and long range of the informal mechanism used to maintain Communism in power. Certainty in the face of grim chaos is powerful. But more powerful, as Milovan Djilas, the Yugoslav critic of Communism, has repeatedly pointed out, is the unwillingness of a people to lag behind economically in a world where to lag means social and political extinction. 11 Thus the present was made bearable by the image of a brighter, industrialized future. The Communists controlled that image. 


\section{THE DIRECTED CONTROLS}

The second category of extrasovereignty controls was that of directed control systems. A directed control system can be considered to be any method or system of control in which the higher agency takes a direct and continuing interest in the affairs of the managed agency. In this method the higher agency plays an immediate and continuing role in the decisions formally taken by the lower agency either by the direct imposition of policy or through functioning as the necessary approver of policy. The directed control systems used were: consultation between the Soviets and the individual East European countries, which took the form of direct communication between the Soviet leadership and that of a specific country; supervision by the Soviet ambassadors of the domestic events in a given bloc country; maintenance of close contact between the various Party organs through the frequent exchange of experts and visitation by Soviet Party "experts"; penetration of vital East European governmental functions by Soviet agents; and, because diplomatic, economic, and political relations were largely bilateral or were functionally so, all communication and coordination was channeled through the Soviet Union.

In the period concerned, the most important, formal, international Party organization was the Communist Information Bureau (Cominform). It was distinct due to its multilateral nature at a time when the burden of Soviet and East European relations was carried through bilateral mechanisms. The establishment of the Cominform marked the beginning of enforced uniformity in East European Stalinism.12 The organization was founded in September, 1947, in 
Poland with its headquarters to be located in Belgrade, Yugoslavia. The organization's journal was titled For A Lasting Peace, For A

People's Democracy, the title having been proposed by Stalin. The founding meeting declared that "two camps," one imperialist and one socialist, had formed and that East-West collaboration was a thing of the past.13 The Cominform helped to re-enforce the Soviet Union at the head of world Communism.

Russian standards as to what was proper in the arts, literature, and science were to be applied in other Communist parties as we11. This was something new, even by the standards of pre-1939 Communist uniformity. 14

The Cominform's purposes were: to politically integrate the CPSU, the East European, and some Western Communist parties; to convey the accepted ideological dogma; guide its application; and monitor its progress, under the watchful eyes of the CPSU and Stalin. In short, the Cominform was to put a stop to "initiative in the ranks."15

The most reasonable conjecture must be that the Cominform was to serve to cover up the increasingly centralized direction of foreign Communism now assumed by the Soviet Union and especially as a means through which she could rap the knuckles of a dissident member Party--the rebuke or discipline coming ostensibly not from the Kremlin but from the collective body. 16

The Cominform's first tactical objective was opposition to the Marshall Plan, 17 the second was the purge of Tito. After the failure of the campaign against Tito, the Cominform was allowed to linger on in Bucharest where its headquarters had been moved following the StalinTito break. 18 The organization was finally disbanded in April, 1956, as part of the' Soviet rapprochement with Yugoslavia. 19

In summary, the extrasovereignty relations, both semiautomatic 
and directed, focused upon two primary objectives: the control of the local East European Parties by the CPSU and the control of the East European governments by their associated Communist parties. Subsequent events were to show that these issues would cause Soviet tanks to roll on more than one occasion.

\section{INSTITUTIONAL REPLICATION}

The third type of informal control was the replication of Soviet institutions in Eastern Europe. Stalinism in the new "people's democracies," was built not only upon the "enforced claim to infallibility" of Stalin and the CPSU and the military presence of the Soviet Union, but also upon the replication of Soviet experience and Soviet institutfons. 20 The guiding principle of this process was that countries with similar or identical institutions would develop similar outlooks upon important questions and would therefore be more easily led. After 1948, the Soviet Union became the universal model to be copied in all important policy questions.21

Stalin's 1952 article restated and reinforced Marxist dogma regarding the relationship between the economic basse and the political and cultural superstructures of a society. Stalin wrote, ". . the relations of production must necessarily conform with the character of the productive forces."22 Industrialization within the context of state ownership was to create the institutional and political similarities needed to hold the Soviet bloc together. Institutional reproduction became a vital necessity. Therefore, the socialist reconstruction of Eastem Europe was to proceed by radical and rapid industrialization, as it had in the USSR in the 1930s. The effect would be social chaos, 
a revolutionary situation in which the Communist party would be the only source of social cohesion, and the "only source of direction" would be "the Ieadership's will."23 Brzezinski has critiqued this aspect of Stalinist dogma:

A belief in environmental influence tends to exaggerate the importance of a community of views between the various leaders and the identity of institutions and socioeconomic systems. Similarity of material conditions becomes one of the vital guarantees of unity of action, and such a similarity can best be established through the duplication elsewhere of the institutions of the dominant power. 24

This Soviet policy was to prove ill-advised as well as dangerous.

Institutional reproduction operated in three important areas outside of the Party, which itself relied upon the Cominform and democratic centralism to enforce uniformity. These areas were: the new constitutions of the East European states, the collectivization of agriculture, and the organizations and methods of economic planning.

Beginning in 1947, the new atmosphere of political uniformity led to a series of East European constitutional reforms. In line with Communist ideology, the new constitutions were created as both a reflection of then current social and political realities and as instruments to be used in the construction of East European "socialism."25 Between late 1947 and 1952, Bulgaria, Rumania, Czechoslovakia, Hungary, and Poland adopted constitutions olosely patterned after the 1936 Soviet "Stalin". constitution. The constitutions of Hungary and Poland even. included praise for the Soviet Union, an unusual practice for a national constitution.

These constitutions were set up as instruments in the "socialist reconstruction" of Eastern Europe. For example, the Polish document 
defined any act "injurious to socialist property" as the equivalent of sabotage or diversion. Czechoslovak legal thought at the time went further and equated such acts with treason.

In their constitutions most of the East European states declared themselves to be "people's democracies." However, the East German constitution followed a slightly different train of thought regarding its political situation. In its 1949 constitution, it declared itself to be a "democratic republic." Supposedily the East Germans had not reached the historical stage in the building of socialism reflected in the term "people's democracy."

The central point regarding East European constitutional revision in this period is that alliance with the Soviet Union became no longer a matter of policy but "an 'organic' quality of the People's Democracy, maturing and strengthening as the People's Democracy transformed itself."

Soviet attitudes toward agriculture and industrial planning were also reproduced in Eastern Europe. The collectivization of agriculture in Eastern Europe had four main goals: to assure state control of the food supply; to generate a labor surplus through farm mechanization; to allow the extraction of capital needed for industrialization through the manipulation of agricultural prices, and to prevent the peasantry from exercising political influence. Collectivization proceeded unevenIy in Eastern Europe. In terms of farm production, the results were far from good. By 1953 only two states, Yugoslavia and Bulgaria, had reached or passed bread grain production levels set in the period from 1934 to 1938. (See Appendix D.)26 In agriculture the impact of Stalinism was disastrous. The "class struggle" was extended into 
agriculture with the idea that the worse the agricultural situation became, the sooner socialization would occur. "Established methods of good farming suffered accordingly."27

There was, however, some degree of relaxation of Stalinist agricultural policies following Stalin's death. The percentage of farm land in the "socialist sector" dropped in Czechoslovakia from 48 percent to 44 percent in 1954, in Hungary from 37 percent to 32 percent, and in Bulgaria from 62 percent to 60 percent. However, in Poland the "socialist sector" increased from 17 percent to 19 percent in 1954 and in Rumania from 21 percent to 26 percent. The greatest increase was in East Germany where the amount of collectivized land increased from 8 percent in 1953 to 30 percent in 1954. (See Appendix E.) A bloc régime's ability to "overcome internal resistance" to farm collectivization can be considered an indicator of that régime's strength. 28

In 1950, various actions taken by. the Soviet Union and the East European states, in accord with the Soviet and East European political agreements of 1943 to 1947, resulted in the East European adoption of mandatory economic planning mechanisms. Semiautomatic or semi-market planning mechanisms were rejected. The Soviet "material balances" method of economic planning was uniformly adopted by Comecon members. 29 The institutionalization of the nonmarket economic model by the East European. countries was not voluntary.

It was imposed on them particularly as a consequence of the outbreak of the Korean War, when individual socialist countries, under Soviet pressure, revised their long-term plans and reshaped them for a speedy militarization of their economies. 30 
One of the more important results of the adoption of the "material balances" mechanism was that the initial economic plans of the group favored individual domestic sources of materials over foreign ones. Bloc trade, both within the bloc and outside of it, was motivated, therefore, by the single need to open economic bottle necks.31 A situation resulted which militated against trade and economic efficiency long after Stalin's death. 32

In summary, the post-Stalin leadership came into an extensive, flexible, and highly useful system of extrasovereignty controls, controls which operated outside the bounds of formal diplomatic agreements and which were in fact superior to them. These informal controls served as the foundation for the structure of formal alliances by which the Soviet Union established its power and influence in Eastern Europe. At those times when the formal alliance structure has shown signs of weakening or breaking down altogether, the Soviets have been able to fall back upon the informal methods of control and/or outright military intervention to restore order, to set the formalities back in their proper, from the Soviet point of view, position and to interpret the alliances' meaning for the East European leaders. 
The intersovereignty control mechanisms used by the Soviet Union fell into two broad subsystems. The first was economic integration involving bilateral trade treaties, the Council for Mutual Economic Assistance (Comecon or CEMA), and Soviet and East European joint stock companies. The second subsystem consisted of a network of treaties of "Friendship and Mutual Assistance" concluded between the Soviet Union and the East European states and between the individual East European states themselves between 1943 and 1952. This collective security subsystem entailed military alliances and formal and subsidiary informal programs of military and police integration.

Before the Second World War, Eastern Europe's main trading relationships were with Germany. However, the established Soviet hegemony prevented any renewal of the prewar trading patterns. ${ }^{2}$ For Bulgaria, Hungary, Poiand, Rumania, and Czechoslovakia, their 1937 trade with the Soviet Union and other East European bloc countries, as a percentage 
generation. Even the emphasis on rapid industrialization, albeit destructive in some of its social consequences, was not without its appeal. Communism seemed to offer a key to the understanding of a complex and often brutally unpleasant past and a straight causeway to a socially controllable future. The era of uncertainty bred many who craved such certainty. The Communists seemed to enjoy a monopoly on the tomorrow to which those who opposed them were no longer able to provide any alternative. Thus even the unbelieving were brought face to face with the dilemma of the one alternative --to oppose Communism was to be against everything and for nothing."

${ }^{11_{S}}$ ee Milovan Djilas, The New Class (New York: Praeger, 1957), pp. 11-14; and Milovan Djilas, The Unperfect Society (New York: Harcourt, Brace and World, 1969), pp. 102-103.

12Brzezinski, p. 62 .

13 Ulam, pp. $460-461$.

${ }^{14}$ Ibid.

15 Nicholas Halasz, In the Shadow of Russia: Eastern Europe in the Postwar World (New York: Ronald Press, 1959), pp. 251-252.

16 U1am, p. 461.

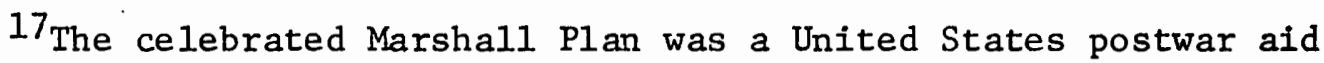
program, the central purpose of which was the economic reconstruction of Europe. See below Chapter III.

${ }^{18}$ Ulam, p. 449.

19 Brzezinski, p. 183. See below Chapter VII.

${ }^{20}$ Ibid, , p. 301.

${ }^{21}$ Ibid., p. 77.

22J. V. Stalin, "Economic Problems of Socialism in U.S.S.R.," in Bruce Franklin, ed., The Essential Stalin (Garden City, N. Y.: Doubleday and Company, 1972), p. 449.

23 Brzezinski, pp. 100-102. 
${ }^{24}$ Brzezinski, p. 135.

25 The following analysis of East European constitutional revision and the direct quotes included derive from Brzezinski, pp. 77-80.

26 Nicolas Spulber, The Economics of Communist Eastern Europe (New York: The Technology Press of the Massachusetts Institute of Technology and John Wiley and Sons, 1957), p. 349.

27 Brzezinski, pp. 141-142.

28 Ibid., pp. 98-99.

${ }^{29}$ Kaser, p. 33. A detailed discussion of the material balances method of economic planning can be found in Robert W. Campbell, The Soviet Type Economies: Performance and Evolution.

30 Radaslav Selucky, Economic Reforms in Eastern Europe: Political Background and Economic Significance, trans. Elias Zdenek (New York: Praeger, 1972), p. 25. 
NOTES

CHAPTER II

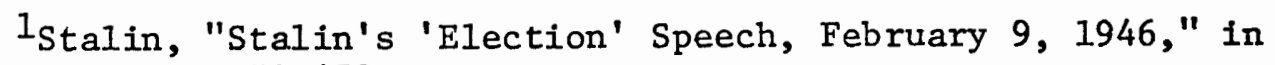
Dmytryshyn, pp. 450-459.

2 The following analysis of semiautomatic and directed control systems derives 1argely from Brzezinski, pp. 111-124, with the exceptions of the emphasis placed upon the "dilemma of the one alternative," the discussion of Djilas' work on the appeal of Communism, and where otherwise noted.

3 Kaser, p. 17.

${ }^{4}$ An analysis of the Soviet-Yugoslav dispute follows in Chapter VII.

5Ulam, p. 466. It should be noted that "Titoism" was only one of several charges used in the East European Communist party purges between 1947 and 1952.

6 Ulam, p. 508.

7Poland was not the only case, only the most celebrated. The Rumanian and Hungarian and the Rumanian and Bulgarian frontiers are guaranteed by the Soviet Union. The case of the Polish and Czech frontier as well as the Czech and Hungarian frontier offer two other examples. The position of the Soviet Union as the arbiter of political frontiers, which was especially the case in the period in question, has given a great boost to its power and influence. Most of the states in Eastern Europe must ask themselves the question regarding their frontiers: If not the Soviet Union, then who will guarantee them?

${ }^{8}$ Schwartz, p. 23.

9 Brzezinski, pp. 80-81 and 133-134; R. E. H. Mellor, Comecon: Challenge to the West (New York: Van Nostrand Reinhold, 1971), p. 133 .

10 Brzezinski, p. 146. The whole passage from which this particular quote derives provides a development of this concept:

". . Probably until about 1951-1952, the Comrunist emphasis on the future, contrasted with a reality still bearing the marks of the German occupation, appealed to many, particularly among the younger 
of their own total foreign trade, ranged from a low of 7 percent for Poland to a high of 18 percent for Rumania. By 1951 these trade percentages ranged from a high of 92 percent for Bulgaria to a low of 58 percent for Poland. (See Appendix F.) 3

Following the Second World War, the traditional Soviet emphasis upon heavy industry was reaffirmed and applied in Eastern Europe. In his election speech of $1946^{4}$ and in his oft-cited article of 1952, Economic Problems of Socialism in the USSR, Stalin argued, and thereby reaffirmed Soviet economic development and defense policies, that heavy industrial development was necessary for defense and economic growth and that a shift to consumer goods production would have the effect of destroying - . the possibility of the continuous expansion of our national economy, because the national economy cannot be continuously expanded without giving primacy to the production of the means of production. 5

The long-standing dogma, coupled with the Soviet policy to rehabilitate economically at a rate comparable with that of Western Europe, led to. the application of methods which imperiled Soviet policy in Eastern Europe. 6 As an example, a manager's failure to fulfill his assigned economic plan quota could lead to criminal charges of negligence and economic crimes against the state. Offenders could be imprisoned or shot. The results of this policy upon the managerial group can be easily imagined. 7

Between 1945 and 1956, about 20 billion dollars were extracted from Eastern Europe in Iine with Soviet objectives to use Eastern Europe as a capital and material source. 500 million dollars of that total were extracted between 1946 and 1956 from Poland through the manipulation of the prices paid by the Soviet Union for Polish coal. This is the most 
familiar example of Soviet price manipulation, but it is not an atypical example. 8

This 20 billion dollar figure can be placed in perspective if it is recalled that the dollar value of the entire wartime destruction of Poland has been assigned a value of 18 billion dollars. Britain's foreign debt at the close of the war totaled 12 billion dollars. Also, the total amount expended during the course of the Marshall Plan (1947 to 1951 ) was 13.5 billion dollars. ${ }^{9}$ For the economic period concerned, 20 billion dollars was an immense sum.

Building upon the foundation of the 1943 Soviet and Czechoslovak treaty, the economic integration of the East European states and the Soviet Union began in 1947. Through 1947 and into 1948, a series of trade treaties granting reciprocal "most favored nation" status was concluded between the Soviet Union and: Rumania (February 20, 1947), Hungary (July 15, 1947), Czechoslovakia (December 11, 1947), and Bulgaria (April 1, 1948). A similar treaty concerning "reciprocal goods deliveries" valued at one billion dollars was signed by the Soviet Union and Poland on January 26, 1948. Also, beginning in 1950 and continuing into 1952, a series of long-term trade agreements, which generally focused. upon the period from 1951 through 1955, was negotiated between the Soviet Union and the East European countries. 10 In addition, between 1950 and 1951 a network of long-term trade agreements was concluded between Albania, Bulgaria, Czechoslovakia, the German Democratic Republic, Hungary, and Rumania. (See Appendix G.) ${ }^{11}$

The most durable instrument of Soviet and East European economic integration has proven to be the Council for Mutual Economic Assistance 
or Comecon. Comecon was founded at a Moscow conference held by Bulgaria, Czechoslovakia, Hungary, Poland, Rumania, and the Soviet Union on January 5-8, 1949. The founding members were joined the following February by Albania, the German Democratic Republic in September, 1950, and by Mongolia in June, 1962. 12 Comecon's founding marked the end of the use of strictly bilateral economic mechanisms in the Soviet bloc..

Though the dangers of economic isolation and defections after 1948 prompted the formation of Comecon, 13 the main purpose of the organization was to provide a necessary alternative to the Marshall Plan for Eastern Europe. 14 In the stated Soviet view, the Marshall Plan was a violation of the participating countries' national sovereignty and meant their economic and political subordination to the "interests of the U. S. monopolies."15 This objection was stated in Comecon's founding communique and was also motivated by a Soviet desire to prevent the formation or pressures for the formation of regional coalitions in Eastern Europe. ${ }^{16}$. However, the Soviet emphasis upon national sovereignty was at sharp variance with East European realities. At no time were the individual East European governments, with the exception of Yugoslavia, more subject to Soviet command. 17

Comecon is particularly significant because it is the first formal, multilateral organization of the governments of the Soviet Union and the East European states. 18 Comecon, the economic counterpart of the Cominform, was founded as a multilateral, economic control mechanism, just as the Cominform was founded as a multilateral, Party control. mechanism.

Comecon's founding communique was published on January 22, 1949 , and served as its only policy statement for 8 years and as its 
constitution for 11 years. The January communique (see Appendix H) stated that as a result of the "considerable success" in the "development of economic relations" between the Soviet Union and the bloc countries, the "great rise in the turnover in trade," the "implementation of economic cooperation" between the new people's democracies and the Soviet Union, and in the face of a trade boycott led by the United States and Great Britain, Comecon was founded by the nations convened with three main objectives. These were: "to accelerate the restoration and development of their national economies," to exchange economic experience, and to extend technical aid and material assistance with particular emphasis upon raw materials, foodstuffs, machines, and other equipment. 19

The long-term significance of Comecon's founding communique lay in the Soviet determination to divide Europe economically as well as politically. 20 This method was in line with stated Stalinist perceptions of postwar economic and political realities.21 These views, which formed the official line, were given concrete, systematic expression by Stalin in his article, Economic Problems of Socialism in the USSR. Stalin wrote:

The disintegration of the single, all-embracing world market must be regarded as the most important economic sequel of the Second World War and of its economic consequences.

The economic consequences of the existence of two opposite camps was that the single all-embracing world market disintegrated, so that now we have two parallel world markets, also confronting one another. 22

The "two camps: two markets" dogma was an outgrowth of the need to generate an atmosphere of crisis as one method to ensure discipline and to legitimize the economic and political primacy of the Soviet Union. 
Under the force of this political and economic dogma, economic contact with the West was considered dangerous, and Western attempts to expand trade with Eastem Europe were treated as "cunning" attacks upon the sovereignty of the East European countries. 23

The question of East-West trade is important. One of the central arguments for Comecon's foundation was that it was necessary to enable the East European states and the Soviet Union to counter a Western trade boycott which had been motivated by the East European refusal to "submit . . to the dictatorship of the Marshall Plan."24 That East European refusal was not altogether voluntary. Czechoslovakia had announced its intention to participate in the Plan, but as a result of direct Soviet pressure, the Czechoslovaks withdrew. Their forced withdrawal brought home to the Czechoslovak government the point that their country was indeed within the Soviet sphere. 25 It must also be recalled that in 1947 , Czechoslovakia was perhaps the last functioning democracy in Eastern Europe; the era of bogus coalition government had set in.

The Comecon charge of Western trade boycott is unfounded. However, two elements, beyond Soviet trade policy itself, did restrict trade in the 1948-1953 period. The industrialization of Eastern Europe severely altered the traditional trading patterns of the area and adversely affected the composition and amount of traditional agricultural products available in Eastern Europe for export. The second element was a Western restriction upon the sale of military and militarily related goods to Eastern Europe and the Soviet Union. This restriction functioned in terms of the nature of the items traded but did not address 
the volume of trade. These restrictions were begun, for example, in March, 1948, by the United States. 26

The volume of trade between the Soviet bloc and Western Europe and the United States, as measured in then current unadjusted dollars, ranged from a low of 908 million in 1947 to a high of 1.3 billion in 1948. The figures for 1949 and 1950 are 1.2 billion and 1.0 billion, respectively. Trade outside the bloc as a percentage of total foreign trade for the bloc countries ranged from a low of 11 percent for Bulgaria to a high of 33 percent for Poland in 1952. (See Appendices I and J.) 27 Subsequently, critical supply bottlenecks in Eastern Europe between 1953 and 1956 forced a reopening of trade with the West. 28 Within the Stalinist context of the period, economic restoration and development was to be accomplished through the operation of the "law of preferential growth of the output of producers' goods." Emphasis was placed upon the autarkic construction of capital goods industries. 29 The concentration of each country on the development of heavy industry required vast raw material resources which only the Soviet Union could supply. As the pattern developed, the Soviet Union exported raw materials to and imported finished goods from Eastern Europe. 30 Consequently, the intrabloc competition for favor with Stalin and the CPSU was further accelerated. The allocation of Soviet raw materials further bound the East European governments and Communist parties to the Soviet Union and to Stalin. 31

Kaser, a British expert on Soviet economics, has identified three phases in the development of Comecon prior to 1956 when the organization began to take on a more definite structure: 
1) 1949-1951: During this period "an initial round of consultation brought long-term agreements on mutual trade, the introduction of triangular deals which began to break the restrictiveness of bilateralism, and permanent arrangements for technical assistance." 32

2) 1951-1953: This was a period of Soviet insistence, without regard to the costs or consequences, upon heavy industry and upon munitions manufacture. During this period, Comecon did not play any substantial role.

3) 1953-1956: This was a period of experimentation during which the mixed companies in several states were dismantled, Soviet extraction of Polish coal ceased, the emphas is upon heavy industry was relaxed, and other reforms were implemented.

The period immediately in question (1949-1953) was one of little activity for Comecon as such. In fact, various sources entirely skip the whole 1950-1959 period, while others begin only with Comecon activities after 1955.33 However, from January, 1949, through November, 1950, there were six sessions of the Comecon council: the constituent conference; the acceptance of Albanian membership; an organizational meeting; a session concerned with scientific and technical cooperation and the consideration of long-term economic plan coordination; the approval of membership of the German Democratic Republic; and a conference on inter-regional trade.34 The acceptance of the Albanian and East German memberships were apparently done by correspondence. Three of the sessions were held in Moscow and one in Sofia. From September, 1950, to March, 1954, there were no sessions of the Comecon Counci1. 35

Comecon served as an umbrella under which Soviet economic exploitation of Eastern Europe proceeded.

From its inception until Stalin's death, there appears to have been little intensive economic cooperation and technical help, apart from Russia's search for know-how and skills for its own industry among East European workers. Little attempt appears to have been made to 
increase inter-member trade, but effort was devoted to series typification and standardization of products to Soviet types and norms. 36

This process provided the Soviet Union with valuable economic and political leverage. The system went even further in this period. In 1950, Comecon introduced the ruble as the intrabloc trading currency. The Soviets thereby gained ultimate power over currency exchange rates within the bloc. This and the consistent lowering of the prices of goods sold to the Soviet Union were the two principal achievements of Comecon in this period. 37 Ulam is more blunt. "Until 1953, Comecon was simply a new piece of machinery for milking the satellites." 38 As was the Cominform, the Comecon was also used in Stalin's conflict with Yugoslavia. Beginning in 1949, Comecon was the central. mechanism in the Soviet economic boycott of Yugoslavia, 39 playing the economic counterpart of the political boycott led by the Cominform.

The third major mechanism of Soviet and East European economic integration was the network of Soviet and East European joint stock companies established largely upon the basis of war reparations paid to the Soviet Union. Some of these companies were the Meszhart, for navigation on the Danube; Maszanlet, a Hungarian-Soviet company conccerned with civil aviation; Sovrompetrol, a Soviet-Rumanian oil exploration and development company; and Gorubso, a Soviet-Bulgarian company concerned with mining. 40 The wartime alignment of the Individual East European countries caused a marked difference in their postwar relations with the Soviet Union. The former allies, Czochoslovakia, Poland, and Yugoslavia, were able to conduct large-scale nationalization programs, receive reparations payments, and in general enjoyed more 
flexible relations with the Soviet Union. The former enemy states, Hungary, Rumania, and Bulgaria, had to pay reparations, were much more tightly bound to the Soviet Union, and in general had to adopt a slower pace of economic nationalization. 41 The fact that in 1945 the Soviet Union became the main holder of former "German" assets in the former East European axis states was a prime conditioner of the economic integration of these countries. 42 For Hungary, Rumania, and Bulgaria, reparations payments had been established as part of the armistice agreements which they signed with the Soviet Union. For Germany, reparations had been established in principle by the Yalta and Potsdam agreements. The Soviet Union was allowed to receive reparations in part by taking over various German and Italian assets in the former East European enemy states. 43

German economic penetration of Eastern Europe had resulted in a substantial German control of the banking, industrial, and commerical structures of its prewar allies. Following the war, Czechoslovakia, Poland, and Yugoslavia recovered those economic assets seized by Germany during the war. However, the Soviet Union received the German assets, many of which had formerly belonged to Britain or France, in Bulgaria, Hungary, and Rumania, despite the fact that many of those assets had been seized by Germany and had in turn been declared by the Soviets themselves as German "war loot." Thus the Soviet Union came into the possession of the fundamental structure of German East European economic penetration. 44

The reparations agreements also established that: Hungary was to pay a total of 300 million dollars in reparations, 200 million to the 
Soviet Union, 50 million to Czechoslovakia, and 50 million to

Yugoslavia; Rumania was to pay 300 million to the Soviet Union; and Bulgaria was to pay a total of 75 million, 25 million to Yugoslavia and 50 million to Greece. By 1948, the period in which these vast sums were to have been paid was extended from 6 to 8 years. The composition of the goods to be used in payment was changed, and the oustanding balances were halved. 45

Reparations payments to the Soviet Union comprised 26.4 percent of the Hungarian national budget in 1946-1947 and 17.8 percent in 1947-1948. The respective figures for Rumania were 37.5 percent and 46.6 percent. However, these rates were reduced in 1948.46 Nicolas Spulber has made the following observation:

Having imposed drastic conditions at the beginning, the Russians could continuously play the role of 'lenient friend' by reducing the bill at the most critical moments. 47

Therefore, reparations payments were also a political weapon.

After the Soviet dismantling programs proved quite counterproductive, 48 the Soviets invested some of their reparations receipts in Eastern Europe in the form of wholly-owned Soviet companies. These companies concentrated in the financial and distribution areas. The Soviet and East European joint companies, in which the Soviets invested the balance of their plant and equipment reparations receipts, operated mainly in the areas of mining and manufacturing. 49 These companies enjoyed many special conditions of operation. In general, they were exempt from taxation, were guaranteed profits from the moment of foundation, had various privileges in the use of foreign exchange, recelved the use of 
special facilities, and were granted "extraterritorial" status. In addition, the joint companies were able to promote their interests across state boundaries. The real power in these companies was held by the general manager, as distinct from the company president, who, interestingly enough, was always a Soviet national.50 To a large extent, therefore, the joint companies developed as an international network in which Moscow acted as the hub and which frequently operated against the economic interests of the specific country in which a given company happened to be located.51 As a result, for the East Europeans, the joint companies were a further burden hampering their postwar economic recovery. 52 The Soviets, however, found these companies extremely profitab le. 53

\section{COLLECTIVE SECURITY}

The second major area of intersovereignty control was the Soviet and East European collective security system. This system was built upor the foundations laid during the establishment of Soviet hegemony in Eastern Europe. As early as April 1945, Stalin is quoted as saying that "whoever occupies a territory" will impose "his own social system" upon it. 54 Thus the Soviet East European bloc received a primarily Soviet military foundation. The Soviet troop level in Eastern Europe in 1947 and 1948 was around 500,000 men, organized in some 30 divisions. 55 As each of the East European countries passed through the various stages of "socialist reconstruction," the Soviet military and secret police were present to "discourage" resistance. 56 
Between December, 1943, and 1949, a series of treaties of friendship, cooperation, and mutual assistance was concluded between the Soviet Union and the various countries of Eastern Europe. (See Appendix $\mathrm{K}$ for the text of a representative treaty.) From 1947 through 1949 an additional series of bilateral treaties of a similar nature was concluded between the individual East European countries.57 The bilateral treaties between the Soviet Union and the East European states stressed the latter's sovereignty, equality, and independence. Nothing in these formal agreements sanctioned the domestic interference of the Soviet Union. 58 This would prove to be a weakness of the system under later conditions.

Brzezinski has characterized these treaties as cloaks "for a relationship of political subservience, with the juridical fiction of equality serving both to mask this relationship and to perpetuate it."59 Ulam has stated, regarding the process of negotiations in the Stalin era:

The past pattern of negotiations between the U.S.S.R. and the satellites was not that involved; representatives of the latter had agreements thrust under their noses and were told to sign. 60

The process was simple and direct; the treaties were meaningless except as interpreted by the Soviet Union.

This network of friendship and mutual assistance treaties formed the legal basis for the bloc's collective security system. Alexandrov has expressed the Soviet view of these treaties as vital to the promotion of "fraternal friendship between the peoples of the socialist countries and ensuring their security and economic and political independence." In line with the Soviet assertion that German imperialism showed "ominous signs" of "resurgence" and that the United States and 
other "imperialist powers" were making "preparations for a war against the USSR and the People's Democracies"; the treaties provided for "joint action" to eliminate the threat of aggression by Germany or any combination of states involving Germany. If one of the signatories of these bilateral treaties was attacked by such a combination, the other was bound to respond with military and other assistance. In the Soviet line, "These treaties were thus directed entirely against the possibility of further aggression by German imperialism."61 The SovietHungarian treaty (signed on February 18, 1948), for example, provided that the signatories would "undertake jointly all the measures in their power to avert any threat of a repetition of aggression" by any German and/or inperialist combination. Further, the signatories pledged: not to join any "alliances or coalitions or take any action or steps directed against the other party," to consult each other on all important international issues, and to act "in a spirit of friendship and cooperation" in cultural and economic relations which were to be founded upon the basis of "mutual respect for independence, sovereignty, and non-interference in each other's internal affairs." After its formation in October, 1949, the German Democratic Republic was brought into the system of "fraternal relations with the socialist states." 62

The German-Imperialist threat was used, at least officially, as the emotional comerstone of the Soviet and East European collective security system. That system provided for close military and diplomatic cooperation between the "countries of people's democracy" and the Soviet Union. Through the Communist political power monopoly and a Sovietenforced "democratic centralism," the Soviets defined the operative 
terms and conditions of the treaties. "Consultation," and "all the measures in their power," and "friendship and cooperation" were exactly what the CPSU and Stalin said they were:

A central element of this collective security system was the integration of Soviet and East European secret police agencies and, similarly, the pre-Warsaw Pact integration of Soviet and East European military establishments. These integrations proceeded on both the formal and informal levels and had devastating results. Radaslav Selucky, an economist who was a member of the "Prague Spring," has identified two essential characteristics which differentiate Stalinism from Leninism. The critical features of Leninism are the dictatorship of the proletariat and democratic centralism. In practice, the result is the actual dictatorship of the Communist party apparat (its bureaucracy) within the context of Party and governmental centralization. However, Stalinism is characterized by the dictatorship of a single individual, in the place of the Party apparat, and the imposition of the state security organs over the Party apparat. The result is political terror. "The suppressive role of the organs of power lacks any sense or system; it is terror existing beyond any legal norms as well as beyond any laws of logic."63 One result of the East European Communist party purges was that the East European secret police organizations became independent of the local Party apparat and subject only to the Soviet authorities. 64 In Poland, Bulgarla, Rumania, and Hungary, the Soviet Union's representatives controlled the intelligence services, recruited agents for the Soviet Union, and had access to lowal secret information. 65 The Soviet penetration of the secret police organizations had two primary goals: to ensure their absolute loyalty to the Soviet Union and to prevent 
the local Party from gaining control of them. In this manner potential opposition to the policies of the Soviet Union was denied the power inherent in access to the state security organs. 66 In Czechoslovakia, for example, the Soviet secret police network from 1949 onward was a separate power within the state, responsible only to the Soviet Union. 67 The East European secret police agencies became states within states, controlled from the Soviet Union and feared by both the general populations and the Communist party memberships. 68

After 1949, the East European armies were revitalized and remodeled on the Soviet pattern. 69 Between 1945 and 1949, the local armed forces were placed in the background, and their officer corps purged of members who were likely to be anti-Communist. The Yugoslav army was unaffected because of the international tensions over Trieste and because the government and Party had firm control of the army. The junior men who were promoted to fill the posts made vacant by the purges could be trusted by the Soviets because the new officers' new status was the result of Soviet policy. In addition to arms standardization and other measures, a system of political control and training was instituted following the Soviet practice. 70

In short, the Soviets had created in Eastern Europe a "separate yet subordinate arm of the USSR army."7I Yet, in the period 1949 through 1953 and later, the burden of Soviet military activity, as a function of the East European bloc, was executed largely by Soviet forces. 72 
NOTES

CHAPTER III

$1_{\text {Khrushchev, p. } 391 .}$

2Me11or, p. 29.

3 Brzezinski, p. 127.

${ }^{4}$ Stalin, "Election Speech," in Dmytryshyn, pp. 455-456.

5J. V. Stalin, "Economic Problems of Socialism in the U.S.S.R.," in The Essential Stalin, p. 454.

6 Mellor, p. 4.

${ }^{7}$ Robert Campbell, The Soviet Type Economies: Performance and Evolution (Boston: Houghton-Mifflin, 1974), p. 45.

8rzezinski, pp. 125-126. The half-billion dollar figure on Polish losses through coal exports to the Soviet Union is at variance with a 900 million dollar figure cited by Kaser, p. 70. Brzezinski is using a figure derived from the 1956 Soviet settlement of Polish claims. Kaser is using figures derived from Western scholarship.

9 Willis, pp. 233, 182, and 197, respectively.

${ }^{10}$ Alexandrov, pp. 69-72.

$1^{1} 1_{\text {Kaser, p. }} 61$.

${ }^{12}$ Alexandrov, p. 73.

${ }^{13}$ Spulber, p. 426.

14 Mellor, p. 10.

${ }^{15}$ Alexandrov, p. 69. 
${ }^{16}$ Mellor, pp. 11-12.

${ }^{17}$ Kaser, pp. 12-15.

-18 Ibid., p. 11.

${ }^{19}$ Ibid., pp. 11-12.

20 Ibid., p. 15.

${ }^{21} 1_{\text {Mellor, p. } 11 .}$

${ }^{22}$ Stalin, "Economic Problems of Socialism in the U.S.S.R.," in The Essential Stalin, pp. 467 and 468.

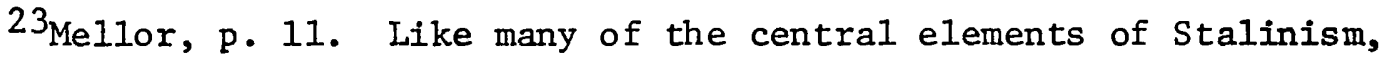
the "two camps" principle has Leninist foundations. The Soviet constitution of 1924 states:

"Since the foundation of the Soviet Republics, the States of the world have been divided into two camps: the camp of Capitalism and the camp of Socialism."

"There, in the camp of Capitalism: national hate and inequality, colonial slavery and chauvinism, national oppression and massacres, brutalities and imperialistic wars."

"Here, in the camp of Socialism: reciprocal confidence and peace, national liberty and equality, the pacific co-existence and fraternal collaborations of peoples." ("Text of the Constitution of the Union of Socialist Soviet Republics," in James H. Meisel and Edward S. Kozera, eds., Materials for the Study of the Soviet System, 2nd., rev. ed. [Ann Arbor: The George Wahr Publishing Company, 1953], pp. 153-168.)

${ }^{24}$ Kaser, pp. 1-12.

${ }^{25}$ Ulain, pp. 421, 432-436.

${ }^{26}$ Spulber, pp. 444-453.

27 Ibid., pp. 463 and 410.

$28_{\text {Me1lor, p. } 96 .}$ 
${ }^{29}$ Kaser, p. 37.

${ }^{30}$ Spulber, pp. 415-416.

$31_{\text {Mellor, p. } 13 .}$

32 This periodization of Comecon's early activities derives from Kaser, p. 39.

${ }^{33}$ Ibid., p. 47.

${ }^{34}$ In this period "consultation" was a process in which Stalin gave orders and the East Europeans tried to follow them.

35 Kaser, pp. $173-176$.

$36_{\text {Mellor, p. } 12 .}$

37 Brzezinski, pp. 127-128.

${ }^{38}$ Ulam, p. 437.

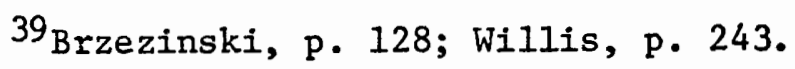

${ }^{40}$ Spulber, pp. 184-194.

41 Ibid., p. xxvii.

${ }^{42}$ Ibid., pp. 35-41.

${ }^{43}$ Ibid.

${ }^{44}$ Ibid., pp. 19, 35-41, 86, 184, 191, and 194.

${ }^{45}$ Ibid., pp. $35-41$.

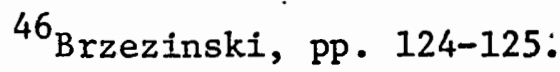

${ }^{47}$ Spulber, pp. 180-181.

48 The Soviet Union had received many factories, installations, and other equipment as reparations. The. "dismantling" programs were an unsuccessful Soviet attempt to remove goods to the Soviet Union for use there. 
${ }^{49}$ Spulber, pp. 184-194.

50 Ibid., pp. 198-202.

${ }^{51}$ Ibid., pp. 202-206.

${ }^{52}$ Campbell, p. 119.

${ }^{53}$ Spulber, pp. 202-206.

${ }^{54}$ Wolfe, p. 9.

${ }^{55}$ Ibid., p. 11.

${ }^{56}$ Ibid., p. 22.

${ }^{57}$ Alexandrov, pp. 62-64.

$58_{\text {Brzezinski, p. } 110 .}$

${ }^{59}$ Ibid., p. 453.

60U1am, p. 493.

61 Alexandrov, pp. 62-67.

${ }^{62}$ Ibid.

${ }^{63}$ Selucky, p. 25.

64 Brzezinski, pp. 119-120.

65 Mackintosh, p. 22.

66 Brzezinski, pp. 119-120.

67 Shub, p. 117. Soviet efforts to control Yugoslavia through the Yugoslav secret police network was one of the major sources of the 1948 break between Stalin and Tito. See Chapter VII.

68 Brzezinski, p. 91.

${ }^{69}$ Wolfe, pp. 42-44. 
${ }^{70}$ Ibid., ; Brzezinski, pp. 121-122.

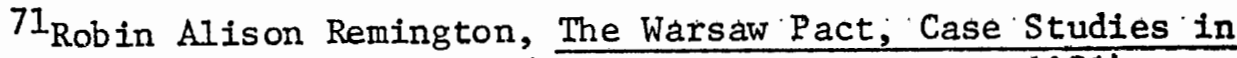
Communist Conflict Resolution (Cambridge: MIT Press, 1971), p. 20.

72 Wolfe, pp. 42-44. 
CHAPTER IV

THE STRENGTHS AND WEAKNESSES OF STALINISM

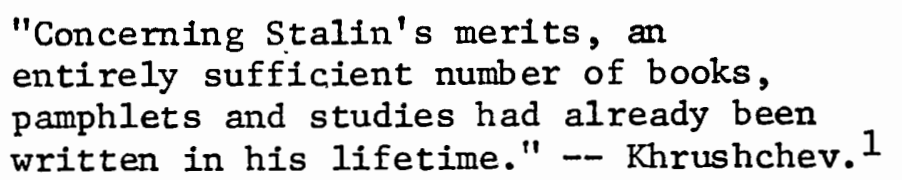

In assessing the strengths and the weaknesses of the system the new Soviet leadership inherited, it is important to recognize that many of Stalinism's strengths became weaknesses after Stalin's death. The converse is also true. Many of the weaknesses of the Stalinist system became strengths, recognized or not, when the new leadership emerged. The criteria by which an element of the system is evaluated are also influenced by the conditions of the specific period in question and whether overall system survival or the ability of the Soviet leadership to exert detailed control is concerned. For example, the radical pace of industrialization in the Stalin era was a principal strength of the system. It helped to ensure Soviet control of the bloc. Yet without Stalin, and because of many additional factors, the pace of industrialization became a weakness. Stalinism is a sharp, two-edged sword of intrabloc relations.

\section{STRENGTHS}

The Stalinist system had three central strengths which were carried over into the post-Stalin era and beyond: the informal, extra- 
sovereignty component; the willingness and ability of the Soviets to intervene militarily both within the context of a collective security system and outside of it; and the genuine Soviet commitment to industrialization. Stalinism relied heavily upon informal and indirect devices to hold the bloc together. Stalin himself was the most important informal instrument of control.2 When Stalin died this linchpin of the system was removed. Stalin, the object of adulation and the source of rigor, was gone. More importantly, the uniformity and'continuity of unquestioned leadership were broken. The Communists who took control in Eastern Europe in the late 1940s were totally loyal, despite a growing domesticism, to the CPSU, to Stalin, and to the USSR. "For years they had been physically supported by Soviet funds and emotionally nourished by Soviet myths." 3 The pathos of apostates such as Milovan Djilas is testimony to the profundity of their commitment. It is true, however, that many were simple opportunists. But, whether through idealism or opportunism, by 1950 the internal factional struggles and purges had eliminated from power those whom the Soviets did not trust or who were not considered experienced Stalinists. 4 This informal element continued to be a strength of the system after Stalin's death. The second strength of the system was the pervasive fact of Soviet power. This power derived from the Soviet position in international affairs and from Soviet willingness to use military force to maintain its interests. Therefore, any domestic tendencies or "efforts to loosen Soviet control" on the part of the various East European leaderships were absolutely constrained by the threat of "a violent Soviet reaction." 5 As the events of 1953, 1956, and 1968 were to prove, the 
"military imperative" has remained a durable instrument.

Regardless of military power, the leading role of the CPSU, or simple idealism, the most vital element of Stalinist control, indeed of Communism as a global, ideological movement, is its commitment to industrialization. This promise was used by Lenin, by Stalin, and by all subsequent leaderships of the Communist movement, both Soviet and nonSoviet, to justify the sacrifices, to gloss over the failures and the horrors, and to legitimize Communist control. In his "secret speech;" Khrushchev made a special effort to draw a clear distinction between true industrialization and the "cult of the individual," between genuine economic growth and Stalinism. 6 The dream, the promise, and the achievement of industrial power are the lifeblood of Communism. It is a commitment, both exploited and fostered, which finally matures and becomes stronger than Communism itself.

Milovan Djilas, the Yugoslav critic of Communism and a one-time close associate of Tito, is eloquent in his description of the desperate appeal of Communism:

The countries which were not yet industrialized ... found themselves in a dilemma; they had either to become industrialized, or to discontinue active participation on the stage of history, turning into captives of the developed countries and their monopolies, thus doomed to degeneracy

No society or nation allows production to lag to such an extent that its existence is threatened. To lag means to die. People never die willingly; they are ready to undergo any sacrifice to overcome the difficulties which stand in the way of their economic production and their existence. 7

It is not the absolute level of production which is important. What is important is the international economic and industrial position of a 
nation. It is this situation, true of all planned and unplanned economies, which allows the Stalinist system to operate.

Herein lies the diabolical genius of Stalin: he realized that Communists, in spite of their troubled human consciences, would go along with his falsehoods and crimes because these were accepted as expedients and sacrifices that had to be made on the Communist party's journey to its true end. 8

\section{WEAKNESSES}

As a system for the management of the East European bloc, Stalinism had several critical weaknesses. These fall into four broad categories: 1) the dependence of the system upon Stalin; 2) the over-dependence of Soviet hegemony in Eastern Europe upon the Soviet military; 3) the inherent nationalism of the East European states which Stalinism could only suppress; and 4) the rigidity of the Stalinist economic model. The central role which Stalin played in the Soviet and East European system has already been touched upon. His image was a real strength while he was alive. Stalin was the object of massive glorification campaigns. His image was a central factor in the stability of the East European regimes. But, with Stalin's death that central figure was gone. Conti-: nuity was broken; there was no "center" for democratic centralism. The importance of the role played by the Stalin myth in Eastern Europe, and the importance of the roles played by those whom Stalin had placed in power was to be learned by the new leadership in 1956 when de-Stalinization turned its belated attention to Stalin the man and some of the less praiseworthy of his fraternal achievements.

As a result of Stalinist economic and political policies, the Communist political monopoly had been established. But the processes 
had generated suffering and bitterness, and the promised results were still far from being realized by the East European populations. The "socialist reconstruction" had worked both ways. The rule of the Communist party had been established, but the generated hostility had made the majority of East European regimes dependent upon direct Soviet support. It is doubtful that in 1952 any of the East European regimes could have maintained themselves in power without Stalin's active support. 9 While Stalin was alive, this situation acted in his favor; with his death, it became an intolerably dangerous situation for the new Soviet collective leadership.

The third weakness of the Stalinist system was the tension generated as a result of the conflicts between the economic and political primacy of the Soviet Union and the irreducible, domestic interests of the East European nations. National "ways to socialism," domesticism, and nationalism had been expressed as early as 1948.10 That expression had focused upon "national ways to socialism" within a context of economic bilateralism and autarky and was permitted in the period before the Stalin-Tito split. That rupture resulted in the suppression of all types of domesticism. The period from 1948 to 1957 was a period, over al1, of conformity to the Soviet model.11 However, if for no other reasons, nationalistic pressures were kept alive and occasionally brought into sharp focus by the process of economic integration. As Kaser has observed:

When the members of an economic union are sovereign nations, their separate interests will make explicit the conflict of advantage which decision-makers within any one centralist state may pass over. 12 
economic advantages and interests. Nationalism is reinforced by this process.

The fourth major weakness of the Stalinist system was the rigidity of the Stalinist economic model. Eastern Europe was made into a carbon copy of the Soviet Union in terms of economic institutions and central economic goals.13 The process went further. Most of the industrial development and reconstruction was done in conformance with Soviet economic and engineering standards and requirements. Much of the new East European capital construction was geared to the use of Soviet raw materials both in terms of technology and resource availability. 14

However, the economic model itself is of central importance. That model was the Soviet nonmarket model, applied rigidly and absolutely.

The political system created by Stalin . . . equated the nonmarket model with socialism itself. Any deviation from that model was considered heresy, treason against socialism, revisionism, and an attempt to restore capitalism. 15

The Soviet economic structure was transferred to the new East European economic planners in its totality. With regard to the rigidity of that structure, Kaser has written, "Soviet planning decisions were made on rules rather than judgements, and rationalized . . as demonstrating conformity with Marxist laws . . . 16 Economic planning decisions were not made with regard to economic considerations, but with regard to Marxist dogma.

Unlike a market mechanism, a material balances economic management and planning system does not, in and of itself, gravitate toward an optimal structure of industrial output.17 Rigidity in the production of consumer and capital goods is one result. In support of this point 
Kaser has explained one of its basic causes as follows:

For a national 'material balance' the fact that production is the starting-line tends to induce a certain automatism in allocation: users are put down for the same shares year after year because assessment of the relative utility of each use is not the responsibility of the producer.18

The pattern of production once set is slow to change, each planning period being little more than a gross update of the last period's allocation and production schedules.

The virtually uncompromising drive toward heavy industrial development in the Stalin era had four basic roots: Stalinist ideology, the political need for an atmosphere of perpetual crisis generated by "socialist reconstruction," the quite genuine need to industrialize to shorten the economic lag between the Soviet bloc and the West, and the automatism of the planning process. Once set as a priority and as a criteria for resource and production allocation, heavy industry proved virtually impossible to renounce.

Fundamentally, . . the Soviet policy favoring the creation of fuel and metal industries in the countries was an autarky inherent in the planning system.19

The priority of heavy industry and national economic autarky placed tremendous strains upon the East European economies.

These strains took various forms in several areas. The fjrst area of interest is resource allocation. The industrial targets set left little scope for domestic resource shifts or changes in trade agreements. ${ }^{20}$ Once a plan was set, there was little that could be done to change it.

The second area of strain was the inefficiency introduced into the system by the pricing mechanisms used. Planning was done in terms of physical production targets. 
The consistency of these goals was effected, as it had been since 1930 , by a complex of 'material balances' but because the units of each were physical (tons, meters, boxes, bales), there was no aggregation, and hence no procedure to reach an optimum, that is, a set of plans which would maximize output and minimize input. More importantly, . . . the prices of the goods balanced in physical terms were all but irrelevant for the production enterprise. 21

But, the problem of allocation and prices was even more extensive.

Aggravating the difficulty of assessing the comparative costs in physical units is the parallel operation of price measurements. Enterprises and countries calculate their transactions in money: the one uses the domestic-price relationships, the other prices in the capitalist world market. Neither set of prices reflects the physical-input coefficients used by the planners-national or international--and the concerns of the monetary planners (the enterprise accountants, the Ministry of Finance, or the foreign settlement department of the national bank) will differ from those running the physical programmes. 22

Thus, efficiency in resource and production allocation are excluded from the system.

The third area of strain is foreign trade. Under the Stalinist economic model, foreign trade had the exclusive function of relieving supply bottlenecks in national economic plans.23 The East European economies were, and are, much more dependent upon foreign trade than is the Soviet economy. Foreign trade is very poorly handled by the Soviet model. This aspect is one of the "conditioners" of the East European reaction to the Soviet model. 24

Stalinism, as a system for the political and economic control of the East European bloc, has several strengths and weaknesses. The basic strengths of classic Stalinism resided in its ability to enforce the political monopoly of the various East European Communist regimes, its consequent ability to control those regimes both politically and 
economically, and in Marxism-Leninism's fundamental commitment to industrialization and economic growth. The basic weaknesses were the inability of "democratic centralism" to overcome nationalism and the fundamental inability of the Stalinist economic model, to provide economic efficiency, balanced industrialization, and the spectrum of economic growth which were the well-springs of its support.

\section{THE IMPERATIVES OF CHANGE}

The specific weaknesses of the system did not in themselves necessitate change. The weaknesses cited have remained in one form or another well into the current period. The strengths of the Stalinist system, many of them inherent strengths of Communism itself, enabled the new leadership to revise the system while remaining in ultimate control. However, Selucky has identified six factors in Stalinism as it operated in Eastern Europe and the Soviet Union which made change imperative. The first of these elements was the backlog of economic reforms which had been impossible to implement while Stalin had been alive. 25 Brzezinski and Kaser support this view. Stalinism was "noticeab1y untouched by innovation and experimentation."26 Economic reforms were either stifled or reversed until after Stalin's death.27 Under the then prevailing circumstances, it is understandable that this was the situation. Selucky has written:

While the dictator with the authority of an infallible leader was still alive, any attempt at changing the state of affairs that had been petrified by Stalin was tantamount to attempted suicide. 28

The second element was the inexplicable, irrational terror which 
was growing in the latter period of Stalin's life. It could not be explained upon the basis of Stalin's personal power requirements. It could, as far as Selucky is concerned, only be apparently explained upon the basis of Stalin's character. 29 Brzezinski is, in a way, more charitable. In 1952 and 1953, Stalin was building the foundations for another series of 1930 s style purges in order to revitalize the system.

In other words, increasingly suspicious that somehow

his system was becoming brittle and static, Stalin was preparing to deal with it in the only way he knew how. 30

But, as Selucky has noted, the purges were contrary to the interests of the Party apparatus, particularly those who lived in constant danger under the direct authority and control of the secret police.

The third element was that the system was contrary to the interests of the technocracy, i.e., the technological and managerial elite. Anything which caused the dis ruption of the frequently unrealistic economic plans could bring charges of sabotage and counter-revolutionary activity against them. "The managers of Soviet enterprises lived almost literally with one foot in prison throughout the period."31

The fourth element was that the system ran counter to the interests of the military. "Ideological limitations delayed the development of cybernetics, physics, and other scientific fields connected with the build-up of Soviet.nuclear and rocket power."32 As far as the military was concerned, it must have appeared as a question of advance technology now or "pay in blood" later.

The fifth element was the intolerably low standard of living which the Stalinist system created. Within the framework of Stalinism, 
an improvement in the stardard of living could not be expected. In terms of agriculture, Stalinism had created such economic conditions "that any coincidence of unfavorable weather conditions could have resulted in famine."33 In this respect Stalinism was operating at sharp variance with Soviet ideology. Schwartz has observed that the Soviet system is finally dependent upon a steady increase in the material standard of living. 34

The sixth element was the over-centralization and militarization of the Soviet economy and the resulting economic losses. These losses were the result of several factors: the deep imbalance of the economy, rigid management, a "nonsensical pricing system," national and regional autarky in terms of economic development, and direct, inexpert "interventions" in the operation of various branches of the economy.

Stalinism was a block upon the interests of the Party, the technocracy, the military, and the general populace. The critically negative aspects of Stalinism were well known. As Selucky has observed,

It was, therefore, no accident that almost immediately after Stalin's death (after June, 1953, upon the liquidation of Lavrenti Beria as a potential perpetuator of Stalinism), a movement started for their gradual elimination. 35

Stalinism, as a total system and in its classic and extreme form, could not endure. It could not survive the death of its creator. It stood between the members of the New Class and their interests. 


\section{NOTES}

CHAPTER IV

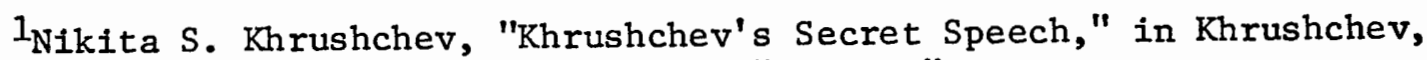
pp. 608. Cited hereafter as Khrushchev, "Speech."

2Brzezinski, p. 111.

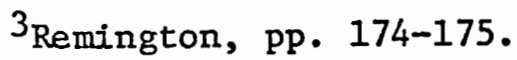

${ }^{4}$ Brzezinski, p. 144.

$5_{\text {Ibid. }}$

$6_{\text {Khrushchev, p. } 615 .}$

${ }^{7}$ Djilas, The New Class, pp. 11-12.

8 Djilas, The Unperfect Society, Beyond the New Class, p. 103.

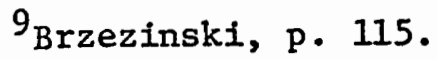

${ }^{10}$ Ibid.

11 Ibid.

12 Kaser, p. 1.

${ }^{13}$ Campbe11, p. 118.

${ }^{14}$ Mellor, p. 89.

${ }^{15}$ Selucky, p. 25.

16 Kaser, p. 17.

17 Ibid., p. 33.

18 Ibid., pp. 35-36. 
${ }^{19}$ Ibid., pp. 19-20.

${ }^{20}$ Ibid., p. 19.

${ }^{21}$ Ibid., p. 29.

${ }^{22}$ Ibid., p. 35.

${ }^{23}$ Campbe11, p. 127.

${ }^{24}$ Ibid., p. 117.

25 Selucky, pp. 32-33. The following analysis derives from Selucky, pp. 32-33, except where otherwise noted.

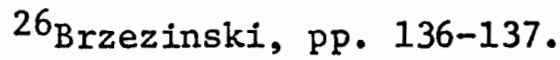

$27_{\text {Kaser, p. } 20 .}$

${ }^{28}$ Selucky, pp. 32-33.

${ }^{29}$ For an interesting look at Stalin through the stages of his decline see Milovan Djilas, Conversations with Stalin. Djilas's description of Stalin at their first meeting in 1944 is worth quoting at length:

"Stalin was in a marshall's uniform and soft boots, without any medals except a golden star--the Order of Hero of the Soviet Union, on the left side of his breast. In his stance there was nothing artificial or posturing. This was not that majestic Stalin of the photographs or the newsreels--with the stiff, deliberate gait and posture. He was not quiet for a moment. He toyed with his pipe, which bore the white dot of the English firm Dunhill, or drew circles with a blue pencil around words indicating the main subjects for discussion, which he then crossed out with slanting lines as each part of the discussion was nearing an end, and he kept turning his head this way and that while he fidgeted in his seat. . . As I later became convinced, Stalin was well acquainted with Russian literature--though only Russian --but the only real knowledge he had outside of Russian limits was his knowledge of political history. (Djilas, Conversations with Stalin, pp. 60-61.)

30 Brzezinsk1, p. 149.

${ }^{31}$ Selucky, pp. 32-33. 
32 Ibid.

${ }^{33}$ Selucky, p. 33 .

${ }^{34}$ Schwartz, p. 154.

${ }^{35}$ Selucky, p. 33. 
CHAPTER V

THE NEW COURSE

\begin{abstract}
"As anyone who knew Malenkov will tell you, after Stalin's death he was completely without initiative and completely unpredictable." -- Khrush chev1
\end{abstract}

\title{
THE OBJECTIVES
}

In June, 1953, workers first in Pilsen, Czechoslovakia, and then in East Berlin, rioted. The immediate sources of the flare-ups were econonic. ${ }^{2}$ of the two, the East German demonstrations are the more significant. The East German regime, highly dependent upon Soviet support, was in a dangerous situation in 1953. As early as April, the East German leadership pleaded with the Soviets to allow an economic relaxation in the form of a reconsideration of the extant capital development policy. Finally, on June 9, 1953, the East German Politburo made a public statement which admitted that "aberrations" had occurred in the past and announced an economic relaxation designed to relieve the most pressing economic hardships. The program involved a reduction of taxes and delivery quotas, the granting of government loans to private businesses, and an increase in various material allocations. 3 However, the situation was beyond the control of the East German regime. On June 16, 1953, a demonstration against an increase in compulsory work norms in the construction industry spread throughout the German Democratic Republic. The Soviets decided to intervene. 
By June 18 , as a result of Soviet military action, order and the Ulbricht government had been restored. 4

The East German riots are important because they demonstrated the ultimate and direct dependence of the East German government upon Soviet military power 5 and, by implication, that the "socialist camp" was held together by little other than the Soviet ability to militarily intervene as necessary. However, the riots left the Soviets with little choice but to recognize that change in the bloc was vital. 6 After all, the Soviet army could not, be everywhere at all times. Therefore, the central goal of the new Soviet collective leadership with regard to Eastern Europe was simply to maintain Soviet power in the area. Because the main pressures which threatened the unity of the bloc were expressed in terms of economics, 7 the Malenkov period was primarily concerned with the economic legacy of Stalinism. 8

The Soviet need to focus their attention upon conditions within the bloc and the stark realities of nuclear war made a relaxation of the Cold War necessary. In August, 1949, the Soviets exploded their first atomic bomb. This development was followed in September, 1953,9 by the first Soviet hydrogen detonation. 10 The Soviet thermonuclear capability was quickly coming of age. First-hand knowledge of the destructive potential of nuclear weapons had a profound influence upon the new leadership: Global war was no longer an international, revolutionary option. 11 The threat embodied in nuclear war made a policy of "peaceful coexistence" an absolute necessity. 12

Because of these circumstances, the "New Course" had three primary objectives: to avoid a nuclear war with the West; to maintain 
and further consolidate Soviet hegemony in Eastern Europe and other areas; and to reform the Soviet and East European system so that it would function more efficiently, but to reform it in such a manner that the substance of Soviet power would not be relinquished. These goals existed within the context of historic Soviet foreign and economic policies. Their object was not the renunciation of the goals of Stalinism and of Marxism-Leninism, but the preservation of the total Soviet system.

\section{THE POLICIES AND SCOPE}

The "New Course," usually associated with Malenkov, who had apparently been designated as Stalin's successor at the 19th Party. Congress in 1952, was based upon two policies: an improvement in the general standard of living in the bloc as a whole and a degree of relaxation in Soviet foreign policy. Politically, Malenkov's policies were characterized by a continuation of Stalinism balanced by a limited economic relaxation. It was an attempt to "pursue a new course in economics without basically altering the framework of essentially Stalinist politics."13

The "New Course" was intended to apply to both the Soviet Union and to the people's democracies. 14 Just as they had followed Stalin, the East Europeans were now expected to follow the "New Course."

Absorbed, in its own succession struggle, Moscow's perception of Soviet-East European relationships continued much in the Stalinist mold. 15

The East European regimes were to duplicate the "New Course" just as they had duplicated classic Stalinism. 16 
The "New Course" involved concessions both real and rhetorical. That concessions were made by Stalin's successors, men politically matured in the traditions of Stalinism, indicates how urgent they considered the post-Stalin situation and how dangerous they believed a continuation of the more odious aspects of the "old ways" to be. 17 In essence the "New Course" was a period of re-examination and intense power struggle. The struggle itself forced a debate on many aspects of Soviet policy.18 The most crucial of these debates was between the Khrushchev and Malenkov factions regarding industrialization.19

Those debates and the actions necessitated by the East European situation resulted in a number of policy changes. The pattern was set by the solution worked out for the East German affair. It contained no political concessions, but economic concessions were made to relieve the political tensions. 20 The following concessions were made in the German Democratic Republic: there was an admission that the pace of industrialization had been too rapid; the allocation of investment was altered by a reduction in the investment made in heavy industry; work norms were lowered; wage taxes and prices were reduced; more consumer goods were made available; travel was made less expensive; pensions were increased; a partial amnesty was granted to minor offenders; on January 1, 1954, reparations payments to the Soviet Union were terminated; and the control of various East German enterprises was returned to East Germany. 21 It is important to note that though the pace of industrialization was admitted to have been too fast, heavy industrialization itself was not repudiated. The issue was one which turned on the rate of industrialization on the one hand and the living standard on the other. 
In Hungary, the results of Stalinist policies had been dangerously sharp. The first five-year plan had called for a 380 percent increase in the production of capital goods. In June, 1953, a meeting was held in Moscow between the Hungarian leadership, headed by Matyas Rakosi, a member of the Hungarian National Liberation Committee and Stalinist hardliner, and a Soviet delegation. The Soviets castigated the Hungarians for economic excesses and insisted on an immediate economic reform to prevent a catastrophe. The Hungarian leadership, the Soviets charged, had driven the country too far. 22 Rakosi was forced to resign as premier, though he remained the First Secretary of the Hungarian Communist party. Imre Nagy, a Hungarian moderate who supported the "New Course," was appointed in Rakosi's place as premier in a strictly formal implementation of the principle of collective leadership.

Nagy initiated the "New Course" with an address to the Hungarian Parliament. While the main focus of his speech was economic, the whole system was essentially criticized. The Hungarian "New Course" included the following elements: the institution of collective leadership, both Nagy and Rakosi holding positions of authority; a partial amnesty along the East German line was declared; prices were reduced; wages increased; compulsory obligations reduced for the labor force; some agricultural deliveries were canceled; peasant taxes were reduced by 15 percent; withdrawal from collective farms was sanctioned; greater religious tolerance was introduced; the internment camps were abolished; the judiciary and the secret police were institutionally separated; and the investment rate in heavy industry was reduced. 
Rumania, Bulgaria, and Czechoslovakia were the next states to adopt the "New Course." The Czechoslovak reform had five elements: taxes were reduced; wages were increased; delivery quotas were reduced; a limited permission to withdraw from collective farms was granted; and the rate of industrial growth was reduced. Poland was the last state to adopt the "New Course." The Polish economic concessions were: a reduction in taxes, delivery quotas, and of accumulation in national income; and an increase in the availability of consumer goods.

Dmytryshyn has summarized the uniform elements of the "New Course": Each satellite regime adopted the principle of 'collective leadership,' and promised (alongside continued industrialization) to improve the standard of living; to abandon the policy of economic autarky; to increase wages and to decrease prices; to give increased attention to agriculture; to slow the tempo of collectivization; to encourage initiative in small production and trade; to curb the activity of the police; and to release those who had been imprisoned unjustly.

Though the first bilateral steps toward truly joint economic planning were taken during the "New Course," the most striking economic reform was the dismantling of the network of Soviet companies and Soviet and East European joint stock companies which operated in Eastern Europe. 24 Most of these companies, located in Hungary, Rumania, and Bulgaria, were dismantled by a series of bilateral agreements in the autumn of 1954 with the remaining companies disbanded in 1955 or 1956 . The more important of the companies to the Soviets were the last to be transferred to local state ownership. Those states were to pay for the Soviet's equity in yearly installments. Due to the terms of the transfer of ownership, Spulber has asserted that those payments could be termed a "second round of reparations." The companies had been 
extremely profitable for the Soviets. Only Soviet awareness of the pent-up East European resentment to the companies caused the Soviets to transfer ownership to the local states. 25

The policies of the "New Course" were a mixture of Stalinism and a relaxation of both internaitonal tension 26 and the methods by which the Soviets maintained their hegemony in Eastern Europe. What is important to note is that neither the maximum goal of Soviet foreign policy, nor the leading role of the CPSU, nor the diplomatic and economic primacy of the Soviet Union, nor the fundamental commitment to the development of heavy industry were abandoned.

The "New Course" Iasted from June 26, 1953, the date of Beria's arrest, until February 8, 1955, the date of Malenkov's "resignation" from $h$ is post as chairman of the Council of Ministers. It existed as an attempt through economic, political, and foreign policies to redefine Stalinism in such a way that the Marxist-Leninist system and the "socialist camp" would function and endure. The "New Course" was not revolutionary; in the final analysis, it was a matter of degrees. The general standard of living did improve, but it did not receive absolute priority over heavy industry. The power of the secret. police was reduced, but the basic organizational structures, with some reforms, remained in operation. Foreign tension was relaxed, but: the Cold War was hardly a thing of the past.

\section{AN ASSESSMENT}

Because the "New Course" existed within the context of Stalinism, it rétained the principal. strengths and weaknesses of Stalinism. It 
both lessened the tensions acting to disintegrate the "socialist camp" and, in many ways, critically increased them. In terms of the Soviet East European bloc itself, the strengths of the "New Course" were: foreign trade increased; 27 the standard of living increased; as a result of the East European replication of "collective leadership," many new, sometimes more popular figures were brought into the various East European leaderships, for example, Imre Nagy in Hungary; there was an increased recognition of peculiar domestic factors in the application of Soviet policies to the East European states; 28 the total flexibility of the system was increased; and none of the substance of Soviet power had been renounced.

However, the "New Course" was a period of power struggle characterized by a continual crisis of authority. In such a period, and particularly in the Soviet system, the operational capabilities of a government are reduced.29 Marxism-Leninism is a governmental system which tends to focus power in the hands of a single individual. 30 The "New Course" was that period in which the system, in the form of the choices and the actions of individual men, began to concentrate that power in the person of Nikita Khrushchev. It is from this condition of "leaderlessness" that the main weaknesses of the "New Course" derive. These were: Soviet policy in Eastern Europe as a whole lacked coherence; 31 in Poland and Hungary the "New Course" was "insufficient to resolve the dilemmas bequeathed by Stalinism without a clear and sustained Sovlet involvement";32 under the policies of the "New Course," controls were relaxed to permit slight variations from the Soviet norm, yet there were no clearly defined limits to those variations;33 
ideological fissures were opened by the "New Course"; the Soviet leadership itself was deeply divided about the wisdom of the "New Course"; and finally, many of the "little Stalins," such as Rakosi, were st111 active.

\section{THE SOURCES OF FAILURE}

There were, consequently, two reasons why the "New Course" failed. The first was that it left unresolved, almost by definition, the question of Soviet leadership. The clear, uncompromising direction which so characterized the Stalin era was critically lacking. The ability to maneuver and to respond quickly, except in the most clearcut cases, was lost. The second reason is attendant upon the first. There were no clearly defined limits set upon the national variations of socialism which had been enabled by the "New Course." To an extent this was inevitable. Without defined and recognized leadership, defined policies are impossible.

The power struggle within the Soviet Communist party, which had been the source of the principal weaknesses and ambivalence of the "New Course," was largely resolved with the "resignation" in February, 1955, of Malenkov as Chairman of the Council of Ministers of the USSR. From that time, Khrushchev was to emerge as the clearly dominant figure in the Soviet leadership. The conditions under which the power struggle was resolved and the concrete questions of policy upon which it turned set the immediate tone for the active concern of the Soviet Union in the affairs of Eastern Europe for the balance of 1955 and most of 1956. The resolution of the struggle itself set the foundations 
for the revitalization of the "leading role" of the Soviet Union in the bloc.

In 1953 Malenkov and Khrushchev held similar views regarding economic policy and of the role of the development of heavy industry in that policy. However, Malenkov's position shifted in favor of the development of light or consumer goods industry. A conflict developed between them in terms of the "actual priorities in the allocation of resources to producer and consumer industries." 34 Khrushchev's position continued to stress the development of heavy industry. His view found its way into the official Soviet press by late 1954. The conflict broke into the open on December 21, 1954. Pravda, the Party journal, supported Khrushchev's position, while Isvestia, considered to be the government publication, supported Malenkov. The public broaching of the issue left the East European leaderships without a clear direction. 36

However, in late 1954 or very early in 1955, Khrushchev gained the support of the Party's Central Committee and the military for his position regarding the rate and method of heavy industrial development.37 During the course of the debate, Khrushchev "assumed the role of a Leninist revolutionary" struggling against the bureaucrats by his support of "new and dynamic schemes of internal reconstruction."38 At the same time, Malenkov's pro-consumer goods position was charged with being an "un-Marxist abandonment of heavy industry" and a threat to Soviet defense capabilities. 39 Under such pressure, Malenkov was forced to resign on February 8, 1955.40 
However, there was an equally important issue to that concerning the relative priority of heavy industry. It centered on the defense policies of the Soviet Union, the importance and geopolitical meaning of nuclear weapons, and military doctrine. Again, Malenkov and Khrushchev took different sides. Stalin had established as Party doctrine the view that the Soviet system was automatically superior to any other. In the immediate post-war period this view, which necessitated the adoption of the correlary doctrine that the Soviet Union could not be defeated regardless of the specific military circumstances, had led to stagnation in Soviet military thought and systems innovation and to an underestimation of the nuclear potential. At the Supreme Soviet session of March, 1954, the Malenkov faction declared that the Soviet military possessed all that was needed to properly defend the country. On the other hand, the Khrushchev faction called for a further strengthening of the Soviet military. 41 The issue was joined.

The defense debate hinged on the role that nuclear weapons would play.in a future war. Through 1953 and 1954, Malenkov's position was that the destructive potential of nuclear weapons acted as a deterrent of global war and that such a war would destroy human civilization. This threat set limits beyond which the nuclear powers could not go in the pursuit of their goals. However, within those limits the Soviet Union and the United States were viewed as still being able to maneuver much as before. 42

On the other side of the debate was Khrushchev's faction and the main group of top military professionals. Their position stressed the possibility of a suxprise nuclear attack by the United States and that 
this possibility required a "drastic reorganization of military doctrine." The theory upon which the Malenkov faction relied, the mutual deterrence of nuclear weapons, was specifically repudiated by Marshall Georgii Zhukov, the most prestigious Soviet commander of the Second World War. The object of the Khrushchev faction was the establishment of a Soviet military which was capable of not only "preventing a nuclear war, but of waging it" also. 43

It seems that Mr. Khrushchev agreed with the Generals that once a weapon had been invented in this world of strife it was the duty of statesmen and their military advisers not to rely on its deterrent qualities, but to prepare the country for its use, both defensively and in the context of a forestalling blow against an enemy about to strike. 44

Thus Khrushchev's position called for caution and capability, while Malenkov's called for caution and a very non-concrete trust in the deterrence of nuclear weapons and in the inherent superiority of the Soviet system.

\section{THE RESULTS}

Following his "resignation," Malenkov retained his position in the Party Presidium and continued to hold a ministerial position. His position in the Soviet leadership may have been "down graded" even before February, 1955. Malenkov was absent from a delegation headed by Khrushchev and Bulganin which went to China in September, 1954.45 However, Malenkov was not powerless. From his position on the Party Presidium, he was later to organize a group which tried unsuccessfully to oust Khrushchev in 1957. 
The resolution of the Party power struggle did not immediately result in a more clearly defined Soviet East European policy; it only increased the ability of the Soviets to form such a policy. Brzezinski has characterized the situation faced by the East Europeans as late as the summer of 1955 as follows:

The internal Soviet ambivalence in policy and the reduction in international tensions produced the belief that the People's Democracies could now afford to frame their policies to fit their domestic requirements. 46

Without clear directives from the Soviets and within the context of reduced international tensions, the East Europeans mistakenly assumed that the time had come in which they could formulate and implement policies more in keeping with their own national interests. The subsequent course of events was to demonstrate that where East European and Soviet interests were at odds, the East European leaders were wrong. 
NOTES

\section{CHAPTER V}

$1_{\text {Khrushchev, p. } 431 .}$

2 The Pilsen riots were sparked by a currency reform. (See Brzezinski, p. 162.)

$3_{\text {Brzezinski, pp. 157-158. }}$

${ }^{4}$ Dmytryshyn, p. 288; David J. Dallin, Soviet Foreign Policy

After Stalin (New York: J. P. Lippincott Company, 1961), Pp. 175-176.

$5_{\text {Dmy tryshyn, p. } 288 .}$

6F. Roy Willis, Europe in the Global Age: 1939 to the Present. (New York: Dodd, Mead and Company, 1968), p. 295.

?Many of the economic pressures grew to the extent that by the 1970s they constituted a major threat to the various East European Parties' political control of the local economy. In the early 1970s a real conflict developed between economic and political criteria in determining various national policies. (See Selucky, Economic Reforms in Eastern Europe: Political Background and Economic Significance.)

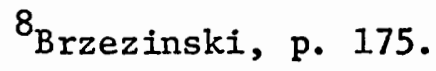

${ }^{9}$ This was six months after Stalin's death.

10 Willis, p. 49.

${ }^{11}$ For Khrushchev's reactions to the possibilities of a nuclear war as an instrument to spread the Communist revolution, see Khrushchev, pp. 518-520, 546, and 569-570. As far as Khrushchev was concerned, nuclear war was not an option. However, it was not possible to ever publicly appear to have completely ruled it out. The image of fear, he believed, would only serve to increase the danger.

${ }^{12}$ Willis, p. 113. 


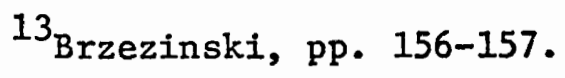

${ }^{14}$ Ibid., p. 157.

15 Remington, p. 29. The apparent lack of concern on the part of the Soviet leaderstip as to the specifics of how the "New Course" was to be replicated in the East European states led to a relative political vacuum. This lack of direct involvement, which was, however, by no means totally absent, was one of the major threats to Soviet control.

$$
\begin{aligned}
& 16 \text { Ibid., p. } 29 . \\
& 17_{\text {Ulam, p. }} 548 .
\end{aligned}
$$

18 Brzezinski, p. 154. In addition, Brzezinski notes that there was an effort on the part of the new leadership, once Beria was out of the way, to avoid the concentration of all power in the hands of one man. However, considering the nature of the power struggle, it may be more likely that no single individual was able in the period from 1953 to 1955 to gain enough support to either ignore the rest. of the leadership or to assume a dual role as both head of the Party and head of the government. Khrushchev was not able to do so until 1958, even though he was clearly the dominant figure by early 1955. (See also Brzezinski, p. 155.)

${ }^{19}$ For an examination of the Malenkov and Khrushchev power struggle, see below.

20 Brzezinski, p. 158.

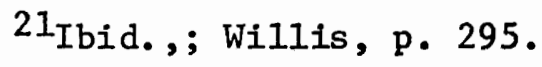

22 These summaries of the reforms adopted as a result of the implementation of the "New Course" in Eastem Europe derive from Brzezinski, pp. 158-163.

${ }^{23}$ Dmytryshyn, p. 289.

${ }^{24}$ Kaser, pp. 32 and 33.

${ }^{25}$ Spulber, pp. 166, and 202-206.

26 That the Soviets did to some extent relax their extra-bloc foreign policy is reasonably clear. The Cold War was not abandoned; it did not go away; but neither was it pushed with the strength and 
determination of either earlier or later periods. Soviet foreign policy in this period was an extension and implementation of foreign policy reforms envisioned by Stalin in late 1952 but which had not been put into effect by 1953. The reforms envisioned a "wait and see" attitude with the expectation that the "Capitalists" would destroy themselves as outlined in Stalin's article Economic Problems of Socialism in the USSR of 1952. This policy was also adopted under the pressure of extra-bloc Soviet foreign policy failures such as the Yugoslav, Greek, and Turkish affairs which had lead to the promulgation of the Truman Doctrine. It was also hoped that a less belligerent Soviet attitude would to some extent isolate the United States from its West European allies. Mackintosh, pp. 70 and 87.

Brzezinski has noted that the most outstanding feature of the general reduction in tensions was the signing of the Korean armistice on July 27, 1953. In view of later events, it is also interesting to note that in August, 1953, Malenkov took credit for the general relaxation of tensions and for the exchange of envoys with Yugoslavia. Brzezinski, p. 156.

27 Brzezinski, p. 158.

${ }^{28}$ Ibid., p. 164.

${ }^{29}$ This argument derives in part from Schwartz, p. 144.

${ }^{30}$ Stefan Yowev, "National Communism," Bulletin of The Institute for the Study of the USSR 4 (May 1957): 3-18.

${ }^{3 I_{\text {Willis, }}, \mathrm{p} .} 337$.

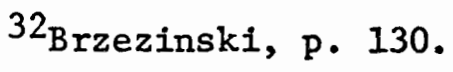

$33_{\text {Willis, }}$ p. 329.

34Mackintosh, pp. 88-89.

35 Ibid.

36 Ibid.; Brzezinski, pp. 156 and 165 .

37 Mackintosh, pp: 88-89; Brzezinski, p. 166.

$38_{\text {Brzezinski, p. } 166 .}$

${ }^{39}$ Ulam, p. 556. 
40 Dmytryshyn, pp. 268-269. Malenkov's "resignation" was an obviously artificial document. In it Malenkov is supposed to have requested to be relieved of his duties in order to strengthen the leadership. He also states that he had an inadequate background in Party work and in the direction of economic policy. In view of the fact that he had been a high Party functionary for twenty years and had had responsibility for increasing aircraft production during the Second World War, both causes for inexperience have a somewhat hollow ring. Further, Malenkov took responsibility in his "resignation" for the adverse situation in agriculture, a branch which Khrushchev had headed for six years. He also conceded that the primacy of heavy industry was the only correct policy.

Malenkov's "resignation" provides an interesting confirmation of two of Djilas' arguments. The first regards the primacy of the Party organs as opposed to the governmental organs. Khrushchev was able to overshadow Malenkov because Khrushchev had control of the Party.

But perhaps more importantly, it confirms Djilas' argument regarding the resolution of power struggles within the Communist movement:

- . The group that emerges victorious is the one that is the most consistent and determined supporter of industrialization along Communist lines, $i . e .$, on the basis of total party monopoly, particularly of state organs in control of production. (Milovan Djilas, The New Class, p. 28.)

Though The New Class was published in 1957, it was written in 1953 and 1954. The manuscript was sent out of Yugoslavia in 1954 or 1955. Djilas was expelled from the Yugoslav Party in January, 1954. In 1955 he was tried and imprisoned by the Tito government. ("A Biographical note on Milovan Djilas," in Milovan Djilas, The Unperfect Society, Beyond the New Class, p. viii.) It is likely, therefore, that Djilas wrote the passage in question before the issue regarding industrialization broke into the open in the Soviet Union and before Malenkov's resignation. Certainly, the events were, at the least, contemporary.

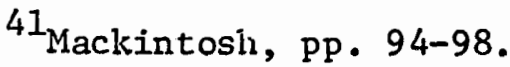

42 Ibid., p. 95.

${ }^{43}$ Ibid. : p. 96; also Ulam, p. 540.

${ }^{44}$ Mackintosh, p. 97. For an interesting and detailed account of the economic, agricultural, and military issues of the Khrushchev and Malenkov debate, see Harry Schwartz, The Soviet Economy Since Stalin, pp. 55-73. In his analysis, Schwartz argues that the thermo-nuclear device detonated by the United States in 1952 was not a bomb as such; 
it was much too large to be transported. In 1953 the Soviets had built an actual bomb. The United States did not develop a bomb until early in 1954. It was this edge in 1953 and early 1954 which allowed the Soviet leadership the military "slack" to promote increased consumer goods production. In 1954 the "slack" abruptly disappeared, and the Soviet military was again able successfully to pressure for a greater heavy industrial and defense investment to counter the United States' increased capability.

$$
\begin{aligned}
& { }^{45} \text { Ulam, pp. 554-556. } \\
& { }^{46} \text { Brzezinski, p. } 167 .
\end{aligned}
$$




\title{
CHAPTER VI
}

\section{THE SOVIET REASSERTION}

\begin{abstract}
"There's no single model or mold wich fits all the countries of the world. To think that there is is just plain stupid, ... Every working class should be able to choose its own course of development on the basis of local historical and economic circumstances --on the one vital condition, of course, that the means of production and the banks belong to the people, and the state is run by the dictatorship of the proletariat."--Khrushchev. 1
\end{abstract}

\section{THE OBJECTIVES RECAST}

It would be convenient to argue that the reassertion of the centralist position of the Soviet Union and the CPSU neatly began on February 8, 1955. That would, however, be wrong. The real substance of the Soviet Union's position in Eastern Europe had not been jeopardized by Stalin's death as such. Indeed, in the long run, Stalin's death made possible the adjustments and reforms necessary if the Soviet system was not to eventually shatter in a torrential bloodletting. After March 5, 1953, the treaty systems, the leading role of the Soviet Union and the CPSU, and the economic dominance of the Soviet Union in Eastern Europe remained in place. Malenkov's resignation is a turning point because it marks the new beginning of continuity in Soviet leadership. There was no return to classic Stalinism; but the unworkable myth of "collective leadership" in a situation of intense power struggle was set. aside. The focus of democratic centralism was restored. It was 
Nikita S. Khrushchev.

The Soviet Union's position in Eastern Europe had, however, been weakened by the reforms of $1953^{\circ}$ and 1954 and by the lack of coherence generated by the power struggle. The weakness lay in the failure of the reforms to clearly and explicitly define the limits to the processes, planned and unplanned, which had been set in motion by the reforms and in the greater failure of the reforms to regularize and perform the necessary restructuring of the Soviet and East European system. Therefore, the reassertion of Soviet centralism was a reform of the previous reforms, the setting of defined Iimits, the regularization of the fragmented bilateral treaty network, and the formalization, i.e., explicit codification, of the Soviet and East European system. In short, after February 8, 1955, the Soviet government began again to function vigorously with consistency and continuity. This was not an overnight shift, but it was the beginning. The time of mourning and confusion was over. Khrushchev's policies had three primary objectives: the avoidance of a-general nuclear war or "peaceful coexistence" as it was phrased, the economic and political integration of the socialist camp, and the regularization of the Soviet and East European system. Seven policies were generated in support of these goals: 1) the continuation of the policy of "peaceful coexistence" from the "New Course" period; 2) the limited admission of Western intellectual currents, a necessity for economic, cultural, and scientific progress; 3) an increase in the rate of heavy industrial development over the rate in the period of the "New Course"; 4) an improved standard of Iiving through an increase in the production of consumer goods, the continuation of another "New Course" policy; 5) the limited recognition of a degree of local East 
European autonomy; 6) an improvement in the general support given to the East European régimes; and, 7) the establishment or revitalization of multilateral control mechanisms. 2 These policies concentrated upon the major areas of Soviet concern: the unity of the Communist movement within the system, economic integration, and the Soviet and East European collective security system.

THE METHODS

As had been the case with the "New Course," the policies of the Khrushchev era operated within the context of Marxism-Leninism and within the context of many of the more important goals and policies of postwar Stalinism such as the commitment to industrialization and the consolidation of the Soviet hold on Eastern Europe. In order to reduce the necessity for constant Soviet involvement in East European affairs and to contain the pressures of the diversity which Stalinism could only suppress or paper over, Khrushchev altered the Stalinist system to create a socialist "commonwealth" based upon economic and institutional processes. At the same time, Khrushchev reaffirmed the imperative nature of ideological unity, defined as adherence to the following basic principles: the leading role of the CPSU in the international Communist movement; the maintenance of the political monopoly held by the bloc Communist parties; and the principle that industrialization and agricultural collectivization were essential components in the process of socialist transformation. 3 Nor was the historic maximum goal of Marxism-Leninism and of Stalinism forgotten. In 1955 the Soviets perceived their opportunities for expansion as being very limited in the Western world. No spectacular situa- 
tions beckoned. This situation was to change sharply, however, the following year. But, especially in 1955, the policy of "peaceful coexistence" cost the Soviets little. ${ }^{4}$ With limited opportunities in the West, the Soviet Union followed a long-established precedent.

Khrushchev's other grand strategy was the old Russian one of expanding in Asia (or the less developed nations in general) to draw strength to fight the West. 5

Thus, the continuity of Soviet foreign policy was maintained through a re-emphasis upon the revolutionary opportunities which existed or which could be created in the colonial or semi-colonial areas of the world. Only the immediate focus and the most extreme method permissible in the promotion of world Communism had changed.

\section{THE REGULARIZATION OF STALINISM}

In the most general sense, the regularization of the Stalinist system took the form of the revitalization of Comecon through the expansion of its functions and the creation of the Warsaw Pact ${ }^{6}$ which was a restatement and redefinition of the Soviet and East European collective security system. These two institutions, both with solid foundations in Stalinism, were to form the underpinnings of the multilateral, intersovereignty relations which were to play an increased role in the Soviet East European system.

Khrushchev's ability to reform Stalinism was limited. His own position in the CPSU leadership was not unquestioned. In 1957 opposition to Khrushchev was to solidify into a challenge from the "anti-Party" group. Also, reforms which might threaten the political monopoly held 
by the Communist parties could not and would not be tried. 7 Furthermore, given the still very active factions within the CPSU, a clear definition of "threaten" was not yet possible. In any reform program, Khrushchev could only go so far as his inclinations and the situation within the CPSU dictated. With regard to Khrushchev's situation in 1955 , it has been asserted that:

Neither then nor in the future was Khrushchev's position as the leader of his country and of world Communism to be strong enough to enable him to effect really fundamental changes in the Soviet system or in foreign policy. 8

On the other hand, the question must be asked: Beyond what was necessary to protect themselves from it, did Khrushchev and the Soviet leadership ever wish to make really fundamental changes in the system which they inherited from Joseph Stalin?

\section{ECONOMIC REFORM AND INTEGRATION}

Despite Khrushchev's insistence upon the need for ideological unity, Stalin's death, the turmoil of the "New Course" period, and the growth of the East European states themselves, made ideological unity a somewhat tenuous affair. The Soviet desire for unity had not lessened, but the ability of previously successful methods to obtain it was brought into serious question. As a result the Soviet leadership decided to generally build the unity of the bloc upon the revitalization of Comecon and the foundation of the Warsaw Pact. ${ }^{9}$ This shift to a greater reliance upon multilateral, formal organizations proceeded against the background of a Soviet mandated return to the primacy of heavy industry and its attendant high economic growth rates. Within the context of lessened international tensions and the new doctrine of "peaceful coexistence," 
a more classic industrial development program was in fact a test of the willingness and ability of the bloc leaderships to follow the Soviet Union. 10 Poland and Hungary were to fail that test.

The average growth of industrial output measured as a percentage of the previous year's output for the bloc as a whole (Bulgaria, Czechoslovakia, East Germany, Hungary, Poland, and Rumania) in 1951 was 123.1 percent; in 1952, 119.8 percent; in 1953, 112.8 percent; in 1954, 107.3 percent, and in 1955, 110.3 percent. From the last full year of the Stalin period the rate dropped from 119.8 percent to 107.3 percent in the full year of the "New Course." In 1955, the year the "reassertion" began, the rate rose to 110.3 percent. 11 These figures are, of course, only indicative and must be treated with a good deal of caution. Nonetheless, they do indicate a certain relaxation. In 1952, the rate of industrial output ranged from a high of 124 percent in Hungary to a low of 116 percent in East Germany. In 1954, these rates ranged from 103 percent for Hungary to 111 percent for Poland. In 1955, these rates ranged from 108 for East Germany and Hungary to 114 for Rumania. Therefore, though the pace of industrial development was resumed, there was no return to the counteproductive growth rates characteristic of the Stalin era. (See Appendix L.) 12

The pace of industrialization slowed in 1.953 and 1954; however, economic growth continued. With the resolution of the power struggle within the CPSU, the emphasis upon heavy industrial development was restored, though not to the extent characteristic of classic Stalinism. The growth rates fell as part of the "New Course," but that was only part of the reason. The pace also slackened in some part due to the confusion within the Soviet leadership and, therefore, within the 
East European leaderships as well.

Within this situation, the Soviet leadership hoped to promote Soviet and East European economic integration as a material foundation for bloc unity. Though Comecon has gone through substantial reorganization and evolution, the Soviet leadership's hopes for it as the basis of economic integration have been somewhat disappointed. 13 This has been largely due to the inability of the Soviet and East European system to shed the basic economic autarky of Stalinism. 14

Until the early 1960s, economic reform in Eastern Europe and the Soviet Union was limited to bureaucratic and administrative reforms of the basic Stalinist model. For example, the degree of economic liberalization which took place in Poland between 1956 and 1958 was followed by a return to more Stalinist methods. 15 Further, the administration of the Soviet economy was reorganized in 1953, 1954, and 1957. However, though the leadership was willing to try "radical" innovations in the bureaucratic structures, they remained firm on the maintenance of "the primacy of state planning, the dominant role of the Communist Party," and "the continuance of socialized farming."16 Until 1955 or 1956, Soviet diplomats and advisers in Eastern Europe simply "gave orders to local officials on major questions of economic policy."I7 Though the fundamental attitudes of economic autarky and the "command" system of economic planning remained in force to a greater or lesser extent, the importance of foreign trade both within the bloc and outside of it steadily increased following Stalin's death.18 At a symposium sponsored by the West German Institute for the Study of the USSR in April, 1956, J. M. Letiche, who was then an associate 
professor of economics at the University of California at Berkeley, stated that Soviet trade with Eastern Europe had "become a means of coordinating the plans and directing the economic development of the Soviet and satellite states."19 Letiche also identified several objectives of Soviet foreign trade: to limit Western influence within the bloc; to help increase the Soviet economic growth rate; to channel the controlling proportion of foreign trade of the bloc through the Soviet Union; to promote the socialist development of the bloc; and to create the impression of a market for Western industrial surpluses, while at the same time creating an "atmosphere of needless defense in Western Europe." 20

For these reasons, until the middle 1950s the burden of economic integration and the coordination of economic planning in the bloc was carried by intrabloc trade. However, the coordination of foreign trade was augmented by economic loans, credits, and scientific and technical assistance. 21 On the other hand, working against economic integration, the centrally directed state foreign trading organizations made an effort to insulate their domestic economies from the fluctuations in the markets outside their countries.22

The modest move away from economic autarky increased the importance of intrabloc trade. At the 20th Party Congress, Khrushchev emphasized the necessity for intrabloc economic specialization to free industrial capacity and other resources for the development of agriculture and light. industry. ${ }^{23}$ This was necessary if the bloc was to both improve the general standard of living and at the same time renew the pace of industrial development as called for by Khrushchev's policies. However, in terms of foreign trade as such, political, economic, and military objec- 
tives, as distinct from consumer objectives, were given priority. 24 The new emphasis on the division of labor within the bloc was an integral part of economic integration and further increased the dependence of the East Europeans upon the Soviet Union.25 However, with regard to product specialization, the Soviet attitude in 1955 and 1956 was that, though the East European states were to specialize, the Soviet Union would reserve the right to produce a full line of products. 26 Product specialization began to make some real headway in 1956, but as the product of bilateral arrangements, rather than action taken within the structure of Comecon, though the problem was discussed there. 27

The Soviet decision to establish Comecon as the major institution of economic integration was finalized in May, 1956, with the formation of the first group of Comecon's various standing commissions. This decision was taken in response to several factors, among which were: the successful, increasing economic integration of Western Europe, the political need within Eastern Europe for the creation of a more multilateral agency to promote economic integration which at the same time could be subject to Soviet control, and the objective superiority of multilateral methods of economic integration as opposed to strictly bilateral ones. Since the early middle 1950s, Soviet and East European economic cooperation had taken the form of a drive toward economic integration through the coordination of investment plans, specialization, various joint undertakings, and financial, scientific, and technical cooperation. 28 In 1954, these efforts involved the founding of various special committees. 29 These committees were given a more formalized status in 1955,30 and in May, 1956, were established as formal, standing 
comissions. Kaser has noted:

It was not until some of the eastern European members had begun seriously to examine the standards by which integration could be judged that Comecon took on operational form--by the establishment of standing technical commissions in 1956.31

Needless to say, this could not have been done without active Soviet support and involvement. The standing commissions created gave a new scope to Comecon's activities, 32 and demonstrated the Soviet Union's commitment to revive Comecon as a viable organization. 33

These standing commissions were: agriculture, chemicals, coal, electric power, engineering, ferrous metals, non-ferrous metals, foreign trade, oil and gas, forestry, timber and cellulose, and geology. The latter three were abolished in 1958 when four other commissions were added: construction, transport, economic questions, and light and food industries. 34 The commissions allowed a much broader opportunity for experts and professionals to meet and exchange views than had existed before 1956. Additionally, in 1955 and 1956 the standing commissions and their predecessors became genuine mechanisms for negotiations. 35

On balance, it must be concluded that Comecon was functionally inactive apart from its role in propaganda until 1956. Before that time, economic cooperation had proceeded through other channels, 36 such as bilateral inter-Party contacts and interstate contacts. Comecon was established as a multilateral institution in fact, but bilateral economic mechanisms were not set aside nor would they be. 


\section{THE FOUNDATIONS OF THE WARSAW PACT}

The second post-Stalin instrument of Soviet and East European integration was the Warsaw Pact.37 With regard to the East European states, the Warsaw Pact

. . represented the single most important formal commitment binding the states to the USSR, officially limiting their scope of independent action, and legalizing the presence (and hence the political influence) of the Soviet troops stationed in some of them. 38

The Warsaw Pact was created and evolved as the central, multilateral institution of the Soviet bloc.

The Pact was created for a number of reasons. The most immediate geopolitical reason was the rearmament and admission of West Germany to NATO. 39 The treaty itself makes this assertion. The Warsaw Pact was a response to West German remilitarization and integration into the "north Atlantic bloc." 40 The Soviet position, as stated by Alexandrov, is that the Warsaw Pact is a "purely defensive organization" directed at "safeguarding" European and global peace.

Signed six years after the formation of NATO, the Warsaw Treaty is a retaliatory measure of the peace-loving states against the aggressive activities of NATO and other imperialist military blocs. 41

Ulam has observed that it was only after West German inclusion in NATO that the Soviets came to consider NATO a "direct menace" and responded by the formation of the Warsaw Pact. 42 Remington extends this general argument further. The formation of the Warsaw Pact was a response to and an attempt to prevent West German participation in NATO.43 Indeed, for Remington, "the Warsaw Treaty Organization was not intended to fight but to gain another bargaining card in the Cold War."44 In addition, 
Remington observes:

From a political point of view the minimal nature of that structure was not particularly. important to Moscow. For at that time the Warsaw Treaty was designed to be primarily a prop of Soviet strategy at the Four Power Geneva Conference in July. 45

Based upon the information publicly available regarding the January, 1956, meeting of the Warsaw Pact's Political Consultative Committee, 46 Remington asserts that two views of the Warsaw Pact operated within the Soviet leadership. In line with Remington's thesis, the Khrushchev faction viewed the Warsaw Pact as an organization not intended to play a direct military role, but as an asset "in the cold War." On the other hand, Molotov viewed the Pact as "a vehicle for soclalist consolidation, military preparedness, defense." Because Molotov was caught up in a power struggle in 1957 and "relegated to Outer Mongolia," Remington considers that his view lost in the debate. 47

Though Khrushchev may have viewed the Pact as a new "negotiable" asset in the Cold War, it is unlikely that his view of the Pact was so limited. A structure beyond "minimal" was not necessary, nor even desirable, to the Soviets due to the political control they were able in 1955 to exercise and due to the extent to which Soviet personnel were directly integrated into the East European military. Khrushchev's position in the power struggle with Malenkov, his promotion of military interests, and his alliance with Zhukov indicate that the First Secretary's view of the new Pact was much closer to Molotov's. In addition to the "German motive," the Warsaw Pact was created to replace bilateral, Stalinist methods of control and integration which would not work effectively in the post-Stalin era. The political 
uncertainty of the period created a situation in which a more formal arrangement governing military and political matters appeared very desirable to the Soviets. 48 This second motive is not ignored in Remington's analysis. In 1955, Soviet analyses of the Pact used the terms "participants of the Warsaw Pact" and "members of the socialist camp" interchangeably. "Within this context Moscow clearly perceived the substance of the Warsaw Pact as derived not from its stated aims but from the political system of its member states."49 Brzezinski

has summarized the political aspects of the Pact as follows:

The gradual return of 'content' to the forms of state independence was in this fashion balanced by a treaty which provided for joint consultation on all major issues and Soviet command of all troops, and which did not provide any procedures for withdrawal from such treaty arrangement or for the removal of the Soviet forces.50

Therefore, though the "German motive" was the most immediate in 1955, the more profound reason lay in the Soviet desire to counter-balance the nationalistic forces set in motion by the death of Stalin and the "New Course."

On the other side of the coin, the Pact also promoted some East European interests. Many Pact members deeply feared Germany. 51 Wel1 into the 1960s, the West Germans were a real threat in the minds of many East Europeans and were used as a pretext by several East European regimes for close relations with the Soviet Union, the only means considered available for protection against a remilitarized West Germany. 52 For Poland and Czechoslovakia a territorial question was also involved. In the absence of a general European peace treaty, the Warsaw Pact provided those countries with some assurance of territorial security. 53 
Within this context, the timing of the Warsaw Treaty is important. In December, 1954, the Soviet Union announced that if the Paris agreements regarding German entry into NATO were ratified, the Soviet Union would take counter-measures. On May 5, 1955, the Paris agreements were ratified; and on May 14, 1955, the Warsaw Treaty Organization was formed in Wars aw between the Soviet Union, Albania, Bulgaria, Czechoslovakia, East Germany, Hungary, Poland, and Rumania. However, only the timing of the Pact was influenced by the entry of West Germany into NAT0.54

A second influence upon the formation of the Pact was the Austrian question. In April, 1955, the Soviets held talks in Moscow with the Austrian government. 55 Under the terms of the 1947 peace treaties between the Soviet Union and Hungary and Rumania, Soviet troops were required to withdraw from Hungary and Rumania upon the completion of a peace treaty between the Soviet Union and Austria. 56 The Austrian state treaty was signed on May 15, 1955, one day after the formation of the Warsaw Pact. The Pact allowed the continued presence of Soviet troops in Hungary and Rumania. 57 Indeed, the Warsaw Pact was used to legalize the presence of Soviet troops throughout Eastern Europe. 58

From the brief analyses given above, it is reasonable to conclude that the "German motive" was a substantial part of the Soviet decision to form the Pact, but that the Pact would have been formed regardless for more fundamental political reasons. The German threat in the minds of the East Europeans was used by the Soviets to promote their position in the bloc and to generate support for a more extensive collective security organization. In the face of the realities of nuclear war, it is hard to credit that the Soviets felt threatened by West Germany 
as such. Therefore, it must be considered that the Warsaw Pact had its origins within the dynamics of the bloc and the need for a new basis of unity. The formation of the "Warsaw Pact" would have taken place in any event; only the timing and the specific content of the treaty were genuinely influenced by the then contemporary geopolitical questions operating outside the bloc.

The Warsaw Security Pact is a treaty of friendship, cooperation, and mutual assistance. The main provisions of the treaty are that the contracting parties shall: strive for "effective measures for universal reduction of armaments and prohibition of atomic, hydrogen and other weapons of mass destruction"; consult with one another on all important international issues "affecting their common interests," especially in the case of the development of a military threat; in the event of an armed attack upon one or more of the contracting parties, the other parties shall come to its aid immediately; establish a joint command for the armed forces; "not participate in any coalitions or alliances and not.. conclude any agreements whose objects conflict with the objects" of the Warsaw Pact; "promote economic and cultural relations between the parties to the Pact." The treaty also provides that the Warsaw Pact shall cease to operate upon the conclusion of a "General European Treaty of Collective Security."59

The operations of the Warsaw Pact are administered by two bodies. The Political Consultative Committee coordinates all Pact activity not of a purely military nature. It considers questions of foreign policy and economic and cultural cooperation. The Unified Command of Pact Armed Forces has authority over those troops assigned to it by the 
member states. Both bodies are located in Moscow. 60

Considered simply as an instrument of control, the Pact has allowed the Soviet Union to conduct political and military monitoring and has provided a reminder of common ideology, emphasized formal ties, and provided a political forum subject to Soviet domination, especially with respect to ideology. It has also acted to facilitate the solution of the problems attendant to the stationing of Soviet troops in Eastern Europe and has furthered the integration of the East European military establishments into an East European defensive perimeter. 61

In many ways, the political benefits to the Soviet Union from the Warsaw Pact have probably been as great or greater than the purely military ones. 62 Apart from air defense issues, for the first ten years the Pact provided a political and propagandistic answer to the inclusion of West Germany in NATO 63 and provided a focus for bloc unity. It was not until the late 1950s that the first steps were taken to elevate the military importance of East European troops in terms of military planning and a truly joint role for Soviet and East European forces. 64 Prior to that time, military integration was largely limited to air defense and the information exchanges necessary for East European production of Soviet-type weaponry. 65 It was not until 1961 that annual combined military training exercises were begun. 66 Further, the actual "loyalty" or reliability of East European troops could not be taken for granted by the Soviets. During the upheavals of 1956 , Hungarian troops actively fought the Soviets, and in Poland a "decisive portion" of the Polish army was prepared to resist Soviet military intervention. 67

Over the years, the Warsaw Pact has proven its value to the Soviet 
Union. It

- . has proven more effective than any other multi-

lateral institution in holding the bloc together and

still provides the basic treaty obligation binding

the East European states to the Soviet Union. 68

The Pact has developed as the central institutional foundation of bloc unity.

Thus between 1955 and 1956 the foundations were set down for the two institutions, the Comecon and the Warsaw Pact, which would prove to be the foci and operational constructs of Soviet and East European economic and military integration, indeed of bloc unity. Both organizations derived from the advantages to be gained by the Soviets and, to a much lesser extent, by the East Europeans through the reworking of previously bilateral economic and military arrangements into more clearly multilateral forms. To be sure, the movement was neither total nor absolute nor exclusive. Other organizations and bilateral treaty systems covering such things as nuclear power and special military accords also played and still play a vital role in the Soviet and East European system. However, the period following the "New Course" saw the formation of the basic institutions through which and around which the subsequent unity of the bloc has been maintained and by which the pressures which have threatened to shatter the position of the Soviet Union in Eastern Europe have been vented. 


\title{
NOTES
}

\section{CHAPTER VI}

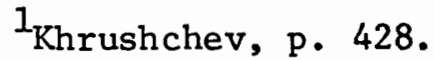 \\ 2Brzezinski, p. 168; Wesson, pp. 110-111. \\ 3 Brzezinski, p. 169 . \\ ${ }^{4} \mathrm{Ulam}$, Pp. 570-571. \\ ${ }^{5}$ Wesson, p. 112 . \\ ${ }^{6}$ Brzezinski, p. 170; Willis, pp. 269-297.
}

${ }^{7}$ Schwartz, p. 150. For a discussion of the anti-Party group, see Chapter XII.

8Ulam, p. 566.

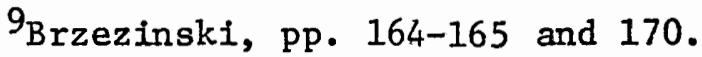

${ }^{10}$ Ibid., pp. 167-170.

${ }^{11}$ The figures cited here are derived from Appendix L. They are given only as indicative of bloc-wide trends and not as rigorous, quantitative measurements in the macro-economic sense.

12 Brzezinski, pp. 167-170.

${ }^{13}$ Schwartz, p. 222 .

${ }^{14}$ Harry Schwartz, The Soviet Economy Since Stalin (New York: J. B. Lippincott Company, 1965), p. 224; Kaser, pp. 23, 24-28, and 158171; and Selucky, pp. 173-179.

The long-range probiems acting against economic integration are generally: the greater degree of political freedom which has developed in the bloc at the national level since 1956 or especially since the Sino-Soviet rift; the inability, at least until the 1970s, to develop 
meaningful price mechanisms to be used in planning and trade due to the still predominant "command, material balances" economic planning system used generally in the bloc; and the semi-autarkic economic orientation of the Soviet and East European leaderships.

15J. Wilczynski, The Economics of Socialism (Chicago: Aldine Publishing Company, 1970), p. 25. Wilczynski is associated with the Royal Military College of Australia.

$16_{\mathrm{H}}$. Schwartz, p. 36.

17Ibid., pp. 219-222. This "informal" aspect of Soviet and East European economic cooperation was subsequently singled out by the Soviet Declaration of October 30,1956 , as a practice which was to be stopped. (See Appendix N.)

18 Wilczynski, pp. 174-175. Also, by 1963, foreign trade has assumed a "greatly enhanced" role as a result of lessened international tensions and the first major economic reforms carried out in the early 1960s.

$19 \mathrm{~J}$. M. Letiche, "Soviet Foreign Policy: Trade and Assistance Programs," in Jaan Pennar, ed., Report on the Soviet Union in 1956 (Munich: Institute for the Study of the USSR, 1956), Pp. 172-191, and 177.

${ }^{20}$ Ibid., p. 184 .

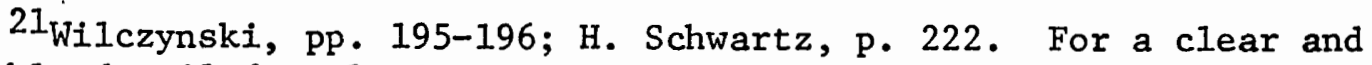
reasonably detailed analysis of Soviet foreign economic relations and the changes which have been by no means minimal brought about after Stalin's death, see H. Schwartz, pp. 189-231.

22

H. Schwartz, p. 219 .

23 Letiche, p. 174 .

${ }^{24}$ Ibid., p. 178.

25 Brzezinski, p. 172.

${ }^{26}$ Kaser, p. 59.

27 Ibid., p. 53.

28Wilczynski, pp. 195-196. 
${ }^{29}$ H. Schwartz, P. 220.

30 Mellor, p. 14.

$3 I_{\text {Kaser, p. } 23 .}$

${ }^{32}$ Ibid., p. 40.

${ }^{33}$ Ibid., p. 59.

${ }^{34}$ Ibid., pp. $67,198-200$.

35 Ibid., p. 67.

${ }^{36}$ Ibid. , : p. 40.

37 Wolfe, p. 3.

$38_{\text {Brzezinski, p. } 171 .}$

39"The Warsaw Pact: Its Role in Soviet Bloc Affairs," a report submitted to the United States Senate Committee on Government Operations (1966), in Vernon V. Aspaturian, ed., Process and Power in Soviet Foreign Policy (Boston: Little, Brown and Company, 1971), pp. 747-768.

NATO refers to the North Atlantic Treaty Alliance, which was formed on April 4, 1949, in Washington, D. C., by the United States, Britain, France, Italy, Belgium, The Netherlands, Denmark, Norway, Portugal, Luxembourg, Iceland, and Canada. The NATO Alliance was an outgrowth of the Marshall Plan and was the basic Western response in terms of collective security to the emergence of the Cold War.

40"The Warsaw Security Pact, May 14, 1955," in Basil Dmytryshyn, pp. 481-484. The full text of the Treaty is contained in Appendix M. Hereafter cited as The Wars aw Security Pact.

${ }^{41}$ Alexandrov, p. 234.

42U1am, p. 505.

$43_{\text {Remington, pp. 10-11. }}$

${ }^{44}$ Ibid., p. 165.

45 Ibid., p. 18. 
46 For a fuller discussion of the Political Consultative Committee, see Remington, The Warsaw Pact.

${ }^{47}$ Remington, pp. 25-27.

${ }^{48}$ Senate Study, pp. 747-749.

${ }^{49}$ Remington, p. 173.

$50_{\text {Brzezinski, p. } 171 .}$

$51_{\text {Ibid. }}$

52 Senate Study, p. 763.

${ }^{53}$ Ibid.

${ }^{54}$ Ibid., pp. 748-749.

55 Mackintosh, p. 105.

${ }^{56}$ Ibid.

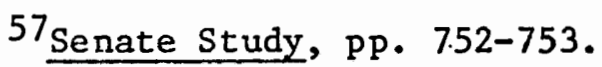

58 Remington, p. 19.

${ }^{59}$ The Warsaw Security Pact, pp. 481-484.

${ }^{60}$ Senate Study, pp. 753-755.

$61_{\text {Ibid., p. } 751 .}$

${ }^{62}$ Ibid., p. 758.

$63_{\text {Wolfe, p. } 148 .}$

${ }^{64}$ Senate Study, p. 755.

${ }^{65}$ Ibid., p. 752.

${ }^{66}$ Ibid., pp. $755-756$.

${ }^{68}$ Ibid., p. 768

67Ibid., pp. 766-767. For an analysis of the 1956 Polish and Hungarian crises, see below Chapter IX. 
CHAPTER VII

THE RAPPROCHEMENT WITH TITO:

THE FIRST ERROR

"After such a long period of hostility,
there was more to restoring relations than
just sitting down at a table and drinking
a glass of wine together." -- Khrushchev. 1

THE PURPOSES OF RAPPROCHEMENT

Following Stalin's death, two main pressures militated against the ability of the faltering Soviet leadership to restore the unquestioned, centralist position of the Soviet Union and the CPSU. These pressures were "separate roads to socialism," as symbolized and practiced by Yugoslavia after 1948, and the Soviet-sponsored de-Stalinization program. Both elements rose from the Soviet leadership's illguided efforts to reform and redefine the Stalinist system in such a way that the bloc would both endure under Soviet influence and function at a reasonable level of efficiency. A policy which allowed "differing paths to socialism" was hoped by the Soviets to provide a structure within which the pressures generated and suppressed by Stalinism could be "harmlessly" vented. It was hoped that a carefully measured increment of "nationalism" would provide a safety valve. In line with these hopes, the Soviets sought to bring Yugoslavia back into the "camp" under conditions that would restate the "Yugoslav path" as an acceptable and 
workable "middle ground" between the unworkable extremes of classic Stalinism and the unacceptable diversity of "Titoism" and remove Yugoslavia as an example of Soviet failure and alternative model of Communism.

The removal of Stalin as an image and source of Communist unity and coherence had two basic sources. Past a certain point, the reforms could not proceed without an explicit denunciation of Stalin and Stalinism. The leadership found in late 1955 that its authority could not be maintained without turning the point of the resentment and hatred released in part by the "New Course" from themselves and the Soviet Union to Stalin and Stalinism. Berla could no longer be made to serve as a proxy for Stalin. The other basic source is grounded in Khrushchev's drive toward power. He used de-Stalinization as a political weapon against the factions which were to emerge in 1957 as the so-called anti-Party group.

However, subsequent events were to prove that the Soviet leadership's hopes were sadly and perhaps even tragically misplaced. The attempts to coax Tito back into the "camp" and the denunciation of Stalin were to prove to be, from the Soviet standpoint, two critical errors, the results of which still hang threateningly over the Soviet Union. 2

\section{THE ORIGINAL CONFLICT}

The Yugos lav Communist Party gained power after the Second World War and stayed in power through their own efforts rather than through "Soviet might."3 It is widely held that in 1947 and 1948, only the 
Communist regime headed by Tito, the principal architect of Yugoslav Communism and leader of the partisan army during the war, 4 had popular support; the other East European regimes, with the possible exception of Czechoslovakia, were kept in power either directly or indirectly by the Soviet army. 5 This condition was at the source of the conflict between Stalin and Tito. The proximate cause of the conflict was Tito's quite understandable unwillingness to place Soviet interests above those of Yugoslavia. 6

As early as 1942 Tito and Stalin had had differences of opinion over operational procedure. 7 By 1945 or 1946, the Soviets viewed Tito's then ultra-loyal brand of Communism, in a period of professed diversity, in paternalistic terms, as one would tolerate a "precocious" child. 8 In September, 1947, the Cominform was founded with its headquarters located in Belgrade, the capital of Yugoslavia. Regarding the location of the organization's headquarters, Phyllis Auty, a British historian and a biographer of Tito, has made this observation:

It sounded like a compliment to the Yugoslavs but was actually intended by Stalin as a means of controlling Tito and gaining more information about what he was doing. 9

By early 1948, the coming split was beginning to materialize. Tito made a clear distinction bétween inter-state and inter-Party relations which made Soviet information gathering activities in Yugoslavia more difficult than elsewhere in the bloc. The Yugoslavs made an. absolute objection to and would not permit Soviet intelligence activities within Yugoslavia. 10 There were several key privileges which Stalin sought in Yugoslavia: control of Yugoslav intelligence organizations, 
Soviet freedom to recruit agents for the Soviet Union, access to Yugoslav secret information, and freedom of movement for CPSU personnel. These privileges, which could have made a satellite of Yugoslavia, were denied to the Soviets by Tito. 11

In a last-ditch effort to control Yugoslavia, Stalin insisted in March, 1948, that Yugoslavia and Bulgaria unite. Yugoslavia refused. 12 On June 28, 1948, Yugoslavia was expelled from the Cominform and charged with a long list of anti-Communist actions, among them that Yugoslavia had taken a position incompatible with MarxismLeninism and that the country had deviated into bourgeois nationalism; 13 a very serious charge in 1948. On the Yugoslav side, they countercharged in 1949, among other things, that Stalin had "reduced the 'creative' substance of the theory [Marxism-Leninism] to a sterile rationalization for his personal dictatorship."14 In the final analysis, it was the Soviet's inability to control Tito that led to the split. 15

The ensuing campaign against Yugoslavia was long and bitter. In the face of the Cold War, the anti-Tito campaign took on the character of a preventive measure directed against factionalism in the "socialist camp."16 Any "laxness" toward Tito within the Communist movement was considered "treasonous" by the Soviets. 17 The bloc also undertook an economic blockade of Yugoslavia. 18 The conflict reached such proportions that Stalin sent agents into Yugoslavia to try to cause a revolt and to assassinate Tito. 19 
Soviet Union began in the summer of 1953 with a proposal to exchange ambassadors. 20 In general, between March, 1953, and early 1954 the Soviets reduced the level of anti-Tito propaganda, proposed the above mentioned "resumption of normal diplomatic relations," pressured the East European régimes to reduce their hostility to Tito, made concessions regarding river traffic on the Danube, "resumed railroad traffic," and released Yugoslav prisoners held in the bloc. 21

The rapprochement with the Soviet Union had begun as a result of Soviet initiative. Khrushchev, in view of the tensions building in the East European states, "needed Tito's support to consolidate his position among the Communist states of eastern Europe."22 For this reason a more public demonstration of the "new relations" between the Soviet Union and Yugoslavia was needed. A visit by the Soviets to Yugoslavia was announced for May, 1955. For his part, Tito was cautious with both the Soviets and the United States, which had extended a substantial amount of aid to Yugoslavia following the 1948 break. Tito was careful to ensure that the United States understood that Yugoslavia was still grateful for the aid received from the West and that no change in Yugoslav foreign policy was "presaged" by the scheduled Soviet visit. 23 However, at this juncture Tito felt some need of a new understanding with orthodox Communism, with the Soviet Union, in order to counter the growing restlessness within the Yugoslav Communist Party. 24

On May 26, 1955, Khrushchev, Bulganin, and Anastas Mikoyan arrived in Yugoslavia and awkwardly blamed the past troubles on Beria. 25 After a series of talks, tours, and parties, a joint statement by the Soviet Union and Yugoslavia was issued which recognized separate paths to socialism. It is important to note that Tito re-enforced his position 
that the talks were between two states and not between two Communist parties by insisting that Bulganin as the Soviet premier sign the communique. 26 Khrushchev, however, was anxious to re-establish Party relations. During the next year, Yugoslavia assumed the role of trusted adviser to the Soviets on East European affairs and to the East European régimes on de-Stalinization. However, the new role which Yugoslavia and Tito were playing in the bloc was having a demoralizing effect upon many of the still very conservative East European régimes. Tito had become a symbol of relaxed control by the Soviet Union over the East European states, 27 a symbol which strengthened the liberal factions within the East European parties and weakened the Stalinists.

One result of the pivotal 20 th Congress of the CPSU held in February, 1956, was the formal adoption of the "many roads to socialism" theory with the important restriction that the Party remain in political control. In line with the newly adopted policy, in April and May many East European leaderships were reformed and formal apologies made to Tito for past wrongs and slanders. In Bulgaria, Vulko Chervenkov, a hard-line Stalinist, resigned as Bulgarian Prime Minister. In Poland, Gomulka, a Polish national Communist who had run afoul of Stalin in the late 1940s, and others were rehabilitated. In Czechoslovakia, former "Titoists" were also rehabilitated. In Hungary, Mathias Rakosi, a Stalinist of the old school who had been a member of the Hungarian National Liberation Committee during the Second World War, admitted his faults and many "Titoists" were rehabilitated. Even Albania, where suspicion of Yugoslav intentions was high due to past border disputes and proposals for "union," managed an apology to Yugoslavia. 28 
Many of the rehabilitations of former "Titolsts" were, of course, posthumous.

Additionally, in 1955 and 1956 various steps were taken to improve economic relations between Yugoslavia and the bloc. And, as a symbol of the new times, the Cominform was disbanded on April 17, 1956.29 It should, however, be pointed out that the Cominform never did a great deal beyond publishing a newspaper, For A Lasting Peace, For A People's Democracy. The organization had held three meetings: one in Belgrade, at which the publication was started, one to expel Yugoslavia, and one to "combat Titoism."30 Apart from propaganda purposes, Stalin had had little use or need for the organization.

THE SECOND DENUNCIATION

During these maneuvers, Tito's attitude remained one of caution. He insisted that relations proceed on a government to government basis. Despite Khrushchev's overtures in 1955, it was only after the "secret speech" that Tito felt able to move towards genuinely closer relations with the Soviet Union. To the Yugoslavs, Stalinism had become identified as the bureaucratization of the state and the transformation of socialism into a form of "state capitalism." Only after Khrushchev had shown decided "proof of his desire and capability to deal with" the bureaucracy were the Yugoslavs able to consider that the "objective" circumstances had changed.

The final proof came only with the Twentieth Congress and with the destruction of Stalin. From that moment on Tito considered himself as Khrushchev's first ally in the crusade against the remnants of Stalinism. 31

In June, 1956, Tito went to Moscow. He offered his support for Soviet foreign policy if the Soviet Union would remove the remaining 
anti-Titoists, allow him a "greater voice in Balkan affairs" outside of Yugoslavia, and recognize "separate paths to socialism" and the "Independence of the satellites." Tito's requests were "politely" refused. 32 On June 20, 1956, the Soviets and the Yugoslavs issued a communique which affirmed the communique issued in Yugoslavia by the two states the previous year. The communique "stressed the permissibility of each Communist country seeking its own way to socialism."33

On the other side of the coin, long before the thaw in SovietYugoslav relations, Tito had resolved that Yugoslavia would not and should not rejoin the bloc. Therefore, despite the Soviet efforts, Soviet and Yugoslav relations could come no closer than the re-establishment of limited economic and political ties. Tito could not be brought back into the bloc, even at the price of Soviet admissions of error. 34

On the Soviet side, the Hungarian revolt in late 1956 strengthened the position of the Soviet conservatives, such as Molotov, and marked the end of direct Yugoslav influence on Soviet policies regarding Eastern Europe. 35 From that time on, Soviet-Yugoslav relations were of an "on again, off again" character. The limit beyond which the Yugoslavs would not go in their efforts to better relations with the Soviet Union and the CPSU was established by the Yugoslav refusal to agree to the declaration issued at the fortieth anniversary celebration of the Bolshevik revolution. Finally, the cooling thaw ended in 1958 with Chinese and Soviet denunciations of the "Yugoslav path."36 


\section{THE INFLUENCE OF YUGOSLAVIA}

The influence of the "Yugoslav path" in 1955 and 1956 upon Soviet and East European relations was by no means minor. Khrushchev had hoped that the Yugoslav example could be made to provide some ground upon which relations within the bloc could be reformed and the growing ferment contained. 37 However, Tito's blueprint for reform, "liberalization combined with nationalism," was increasingly brought into question by the Soviets under the influence of the developing Polish and Hungarian crises. It became clear that Tito had over-estimated the popular support which Communism had in Eastern Europe, at least in Hungary. 38

Among the various East European leaderships, in 1955 and 1956 the Soviet rapprochement with Yugoslavia "could not have been viewed - . with favor."39 For the East European Communists a great deal was at stake.

The Soviet leaders might undermine their own positions if their Yugoslav policy failed; the East Europeans stood to lose their positions as soon as the policy was implemented. 40

In Czechoslovakia, Hungary, Bulgaria, and Rumania, a shift in attitude in the direction of a more favorable stance regarding Yugoslavia by the local Communist parties was considered by them to be a serious threat to their internal solidarity, a solidarity which had been built in large part through an "anti-Tito" campaign and which had been seriously disrupted by the adoption of the "New Course." For example, in 1956, after the Nagy period of 1953 to 1955, when Rakosi was finally able to have the 
"liberal" Nagy expelled from the Hungarlan Party, Rakosi was only beginning to cope with the issues and turmoil caused by the shifts in policy, ${ }^{41}$ which were the result of the reassertion of the Soviet centralist position and the abandonment of the "New Course." "The retention of some forms of Stalinism, and therefore only a partial reconciliation with Yugoslavia, was a sine que non of most of these régimes' political stability." 42

The events which followed the June 20 th communique issued by the Soviet Union and Yugoslavia provided sobering evidence of "Khrushchev's miscalculation concerning Tito" and the additional miscalculation regarding "the capacity of some of the East European régimes to operate beyond the Stalinist framework." 43 The result of the Soviet-Yugos lav rapprochement' was that the common core, the source of ideological unity, was to a limited but critical extent threatened by the Yugoslav support of a "polycentric" view of Communism. In addition, as long as the Soviets supported the rapprochement" with Tito the disintegrating pressures of "Titoism" were more or less free to operate without contradiction. Despite the growing Soviet awareness that this situation was a threat to their hegemony, despite their attempts to narrowly limit the "interpretation" to be placed upon the Yugoslav example,

- . By September 1956, Soviet redefinitions could no longer contain the developments nurtured by the dissipation of Stalinism and crystallized by the reconciliation with Belgrade. 44

Instead of containing the pressures, the Yugoslav model had only served to increase them.

The existence of the Yugoslav model acted as a "spur" to "national 
sentiment" in Eastern Europe. 45 The power of that model was enhanced by the Yugoslav support of Gomulka's return to power as being a "great victory for socialism."46 However, except for Poland and Hungary, "the influence of Titoism in other Eastern European satellites was more psychological than institutional." 47 Poland adopted a carefully measured degree of Titoism and was able to withstand the growing crisis. Hungary attempted to go beyond "Titoism" and was not able to withstand it. Thus, the rapprochement with Tito, the temporary acceptability which it placed upon national Communism, or more simply, nationalism, comprises a major Soviet error in the reform and redefinition of Stalinism. 


\section{NOTES}

CHAPTER VII

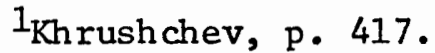

2 The "threat" referred to here is the Sino-Soviet split which was due, at least in part, to de-Stalinization after the ideological ramifications became clearer than they had been in 1956 or 1957.

${ }^{3}$ George W. Hoffman and Fred Warner Neal, Yugoslavia and the New Communism (New York: Twentieth Century Fund, 1962), p. 105. Hoffman is a professor of geography at the University of Texas. Neal is a professor of international relations and government at the Claremont graduate school. For a more detailed treatment of the Soviet-Yugoslav split than can be presented here, see Hoffman, pp. 105-151, for an analysis of the sources of the split and its early history; pp. 421447, for an analysis of the attempted rapprochement'between the Soviet Union and Yugoslavia; and pp. 455-474, for an analysis of the influence "Titoism" has had outside of Yugoslavia. In addition, V. Dedijer's works, Tito Speaks, and Stalin's Last Battle, provide detailed accounts of the Soviet-Yugoslav dispute.

${ }^{4} \mathrm{~A}$ detailed account of the history and background of the Yugoslav Communist party and partisan movement are beyond the scope of this work.

$5_{\text {Halasz, p. } 253 .}$

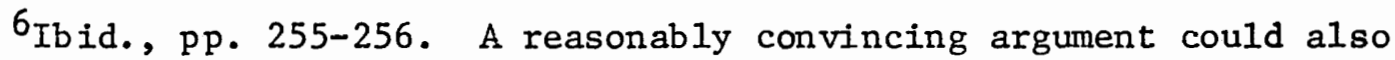
be made that Tito was unwilling to place the interests of ideological dogma, as distinct from Communism, above the interests of Yugoslavia.

7 Ibid., pp. 132-133.

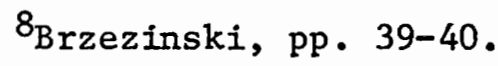

${ }^{9}$ Phyllis Auty, Tito, A Biography (London: Longman Group Limited, 1970), p. 249.

10Halasz, pp. 256-257; See also David J. Dallin, Soviet Foreign Policy After Stalin, pp. 27-34. 
$11_{\text {Mackintosh, p. } 22 .}$

${ }^{12}$ Ibid., pp. 22-23.

13 Halasz, p. 254.

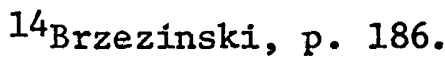

${ }^{15}$ Ul am, pp. 462-463.

16 Halasz, p. 263.

${ }^{17}$ Dmytryshyn, p. 294.

$18_{\text {Halasz, p. } 260 .}$

${ }^{19}$ Auty, p. 254 .

$20_{\text {Hoffman, p. } 421 .}$

${ }^{21}$ Dmytryshyn, p. 295; Hoffman, pp. 421-422.

22 Auty, p. 258.

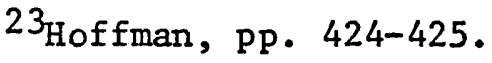

24Ulam, pp. 562-564.

25Ibid.; Dmytryshyn, p. 295.

${ }^{26}$ Auty, p. 255.

${ }^{27}$ Ulam, Pp. 562-564.

28 Mackintosh, pp. 151-152.

${ }^{29}$ Dmytryshyn, p. 295; Ulam, p. 590.

$30_{\text {Hoffman, p. } 127 .}$

$31_{\text {Brzezinski, p. } 190 .}$

32 Dmytryshyn, pp. 295-296. For a discussion of "national Communism" as distinguished from "separate paths to socialism," 
see Yowev, pp. 3-18. "National. Communism" is a term used by Western scholars to refer to "separate paths to socialism" and by the Soviets to charge disloyalty to the CPSU and the Soviet Union. When Tito was accused of "national Communism" in April, 1957, he declared that there was no such thing. All in all, it is a question of subordination or the degree of subordination to the CPSU and the Soviet Union.

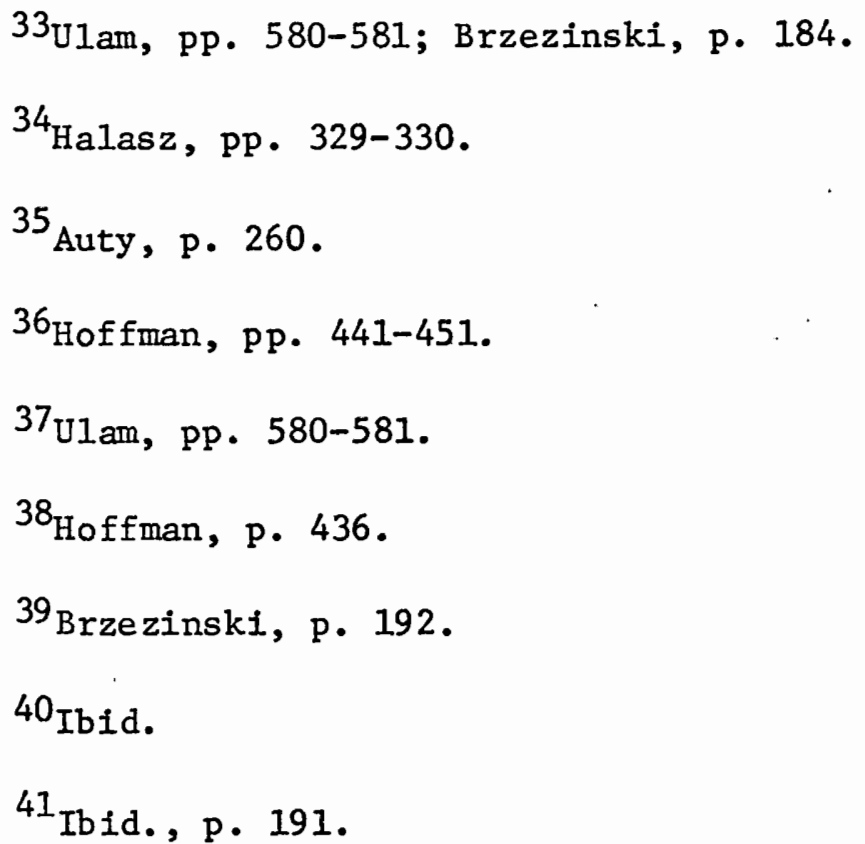

42Ibid., p. 192. The unwillingness of the more conservative East European régimes to fully adjust to the new, Soviet semi-pro Tito line and the general political relaxation in 1955 in effect amounted to a rejection of Soviet practice as a universal norm, that is, a rejection of a primary element of Stalinism. See also Brzezinski, p. 194.

$$
\begin{aligned}
& 43 \text { Ibid., p. } 195 . \\
& { }^{44} \text { Ibid., p. } 206 .
\end{aligned}
$$

45 Hoffman, p. 434. The question must have been asked in more than one East European leadership, "If Tito can follow his own path and still be a part of the 'camp,' why can't we follow our own path?" See also Dallin, pp. 340-357.

${ }^{46}$ Hoffman, p. 437.

47Ibid., p. 468. In addition, see Hoffman, pp. 455-474. 
CHAPTER VIII

THE SECRET SPEECH:

THE SECOND ERROR

\begin{abstract}
"For three years we were unable to break with the past, unable to muster the courage and the determination to lift the curtain and see what had been hidden from us about the arrests, the trials, the arbitrary rule, the executions, and everything else that had happened during Stalin's reign." -- Khrushchev1
\end{abstract}

One of the central issues facing the Soviet leadership in 1956 was the "proper level" of de-Stalinization. At such a level past abuses could be exposed and eliminated in such a way that the Communist party political monopoly would not be threatened. 2 The "secret speech" delivered by Khrushchev to the 20th Party congress on the night of February 24-25, $1956^{3}$ was a crucial event in the search for that "proper level" as well as in the emergence of Khrushchev as the real head of the CPSU. 4

According to Khrushchev, the material in the speech was developed by an inquiry which rose out of the trial of Beria in 1953. Khrushchev felt that the Party leadership would have to give an accounting for Stalin's practices and the remaining aspects of "Stalinism" in the Soviet system. One way or another, sooner or later, the camps would discharge those whom Stalin had imprisoned without cause. Khrushchev argued that it would be better if the "truth" were learned from the 
Party leadership rather than from Stalin's returning victims. In a real sense, the 20 th Party congress was the right time for the leadership to make a "full" disclosure of the abuses of the Stalin era and hope for the best. The 21st congress would be too late. If the Party leadership did not denounce Stalin and Stalinism, the ferment created by the return and rehabilitation of Stalin's innocent victims was likely to be uncontrollable. The practice of blaming "it all" on Beria simply would no longer work. "After Beria's trial we had found ourselves trapped by the version which we'd created in the interests of protecting Stalin's reputation." 5 That reputation could no longer be protected. As Khrushchev wrote, "Murder will out. You can't keep things like that a secret for long." 6 so, to protect the Party and the leadership, the report of the inquiry commission was recast as a speech and Khrushchev delivered it to the 20th Party congress.7

Four major reasons for the "secret speech" have been identified: 1) the three-year old de-Stalinization program could not proceed safely without a specification of the root causes of Stalinist abuses; 2) by performing the expose themselves the leadership hoped to gain credit with the Party membership and to ideologically reactivate the Party rank and file; 3) the regime was in a stable position and felt that it could say in February, 1956, what it could not have said in March, 1953; and, 4) Khrushchev had not been as visible in the Stalin era as the other members of the leadership and by making the speech he could strengthen his position in the power struggle by attracting to himself those who did not wish to see a return to Stalinism. 8

The speech itself made four main charges against Stalin: 1) 
Stalin engaged in "wild terror" in which many good Communists were liquidated; 2) Stalin lost his nerve at the beginning of the Second World War; 3) Stalin ignored the Party and at the same time demanded personal glorification; and 4) on the eve of his death, Stalin was plotting another massive purge of the Party.9 Among the secondary charges were: that anyone who opposed Stalin's ideological viewpoint was in danger of being removed from the leadership and subject to both moral and physical annihilation; Stalin had invented, according to Khrushchev, the concept "enemy of the people" in order to murder his opponents in the 1935-1938 purges; and that Stalin had become psychologically unstable.10 All together, the "secret speech" made some 25 charges against Stalin.11 In addition, Beria was presented as Stalin's chief henchman and as an agent of foreign imperialism. 12

It is also important to note those things with which Stalin was not charged and those aspects of the Soviet system which were not brought into question: Leninism was reaffirmed, though it is doubtful that classic Stalinism could have emerged without its Leninist foundations; 13 Khrushchev was also silent about his own role and the role of the rest of the leadership with regard to the glorification of Stalin;14 Stalin was praised for his efforts against the various factions within the Party, e.g., the Trotskyites, etc. ${ }^{15}$ with the exception of SovietYugoslav relations, Stalin's foreign policy was not mentioned in the speech; ${ }^{16}$ and, there was a clear distinction drawn between industrialization, so long associated with Stalinism, and Stalinist abuses. ${ }^{17}$ Generally, the results of the speech were devastating. The older Party members had known or had suspected what the nature of the abuses 
had been, but the younger Party members were caught unprepared. The revelations made were a "devastating shock."18 Though the results in the Soviet Union itself were not, on balance, as overhwhelming as many had feared, the effects of the speech in Eastern Europe were shattering. The East European leaderships knew that they would be expected to follow the Soviet lead, but they did not have a clear answer to the critical question: How far should de-Stalinization be taken? It was not a simple question. Widespread de-Stalinịation, it was feared, was very likely to spark violent protests against the East European régimes and to ignite the nationalism which Stalinism had only been able to suppress. The abuses could no longer simply be blamed on the excesses of the various security chiefs. Another result was that the intra-Party feuds which the Soviets had held in check now split the various central committees and spilled over into the Party rank and file. 19

The only source of security left to the East European régimes was the Soviet troops stationed there under the provisions of the Warsaw Pact. The situation was such that the allegiance of the East European armies "could not be taken for granted."20 The "secret speech" had two other important political effects. The first was that by destroying the myth of Stalin it allowed Khrushchev to choose those elements of Stalinism which he wished to continue and to conveniently discard the rest. ${ }^{21}$ The second effect was that the speech, combined with the reconciliation with Tito and the abandonment of the "New Course," had created a dangerous "disintegrative process." This was especially the case in Poland and Hungary. 22

The "secret speech" opened fissures in the Communist world; "people 
saw no more reason for blind obedience, and the organs of repression seemed to have lost the will to repress." 23 And at the same time, the central problem remained, and to an extent still remains, the determination of the permissible limits to the process of de-stalinization. 24 
NOTES

CHAPTER VIII

$I_{\text {Khrushchev, p. } 372 .}$

2Ulam, p. 573.

3 Dmytryshyn, p. 485.

${ }^{4}$ Remington, p. 28.

5 Khrushchev, pp. 375-385, for the quote; Remington, p. 29.

${ }^{6}$ Khrushchev, pp. 375-385.

${ }^{7}$ Ibid.

8Ulam, p. 574 .

${ }^{9}$ Ibid., p. 575.

10 Khrushchev, "Speech," pp. 608-677.

11 Dmytryshyn, p. 272.

12Khrushchev, "Speech," p. 658.

13Dmytryshyn, pp. 272-273 .

${ }^{14}$ Ibid.

15Ulam, p. 575.

16 Mackintosh, pp. 154-155.

${ }^{17}$ Khrushchev, "Speech," p. 651.

18Ulam, pp. 575-576. 
${ }^{19}$ Ibid., pp. 576-578.

${ }^{20}$ Ib id., p. 577.

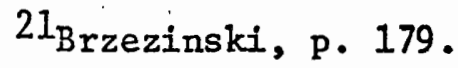

${ }^{22}$ Ibid., pp. 197-198.

23Wesson, p. 144:

${ }^{24}$ Ulam, p. 576. 
THE OCTOBER-NOVEMBER CRISIS

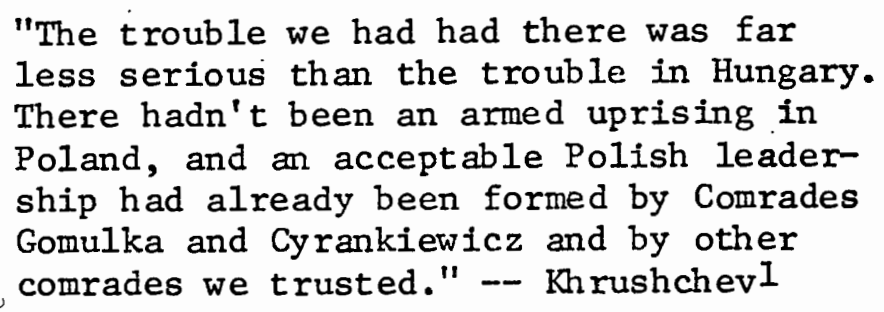

By September, 1956, the disintegrating pressures which the "New Course," the Soviet reassertion, the reconciliation between Tito and the Soviets, and finally the "secret speech" had generated could no longer be easily contained. 2 However, when the ruptures occurred, they did not follow a uniform pattern. The events in Poland and Hungary were the most radical and the most violent. There were a number of reasons for this. First, the economic crisis of 1956 was not as acute in the other East European states as it was in Poland and Hungary. One result of this was that only in Poland and Hungary were the intellectuals at the center of the storm supported by the urban workers. Second, neither Czechoslovakia nor Bulgaria had the deep hatred for the Russians which the Hungarians and the Poles had. Third, in the German Democratic Republic the failure of 1953 was a very fresh memory. Lastly, in Rumania there simply was not a viable political alternative to the régime. 3 Thus, Poland and Hungary became the focal points for the political upheavals of October-November, 1956. 


\section{THE POLISH CRISIS}

The stage was set for the Polish crisis when in 1948 Gomulka was expelled from the Polish Communist party for Titoism. Gomulka's "crime" had been his unwavering support for a moderate policy regarding socialist reconstruction and his advocacy of a Polish way to socialism. 4 In February, 1956, the Soviet denunciation of Stalin's "personality cult". put the "little Stalin" Boleslaw Bierut, who was in charge of Polish Communism, "on the spot." Indeed, the whole leadership of the Polish Communist party, which had followed Stalin's lead in condemning Titoism, Gomulka, and "separate paths to socialism," were brought into serious question. ". . The discrediting of Stalinism was a risky operation, because for most Poles Stalinism and communism [sic] were one and the same thing."5 In April, 1956, a conference of Party activists was assembled to discuss the results of the 20th Party congress. Edward Ochab, an old Party functionary who had replaced Bierut as head of the Party following the latter's death in Moscow in February, 1956, admitted various mistakes and announced the release and rehabilitation of Gomulka. Ochab also promised: to democratize the Polish Communist party, to remove "disproportions" in the economy, to restore economic balance between agriculture and industry, to increase wages for the lowest paid workers, and to curtail defense spending. 6 And, on April 20, 1956, an amnesty was declared for some 28,000 people, many of whom had been political prisoners. 7

Through the spring of 1956, the ferment continued to grow as demand and concession followed one upon another, each building upon the 
last. Things, as far as the Party was concerned, were getting out of hand. 8

Now, the 'thaw' became really dangerous for the party because the people began openly asking whether Stalinism alone was responsible for the soulless society created in Poland during the last decade. The party leadership was simply carried away by a trend which it considered dangerous, yet unable to stop. 9

The immediate crisis in Poland began in June, 1956, with the famous Poznan strike. The issues centered around the worker's living standards and the working conditions at the Zispo plant. The strike became violent, and the Polish army was called upon to restore order. Estimates of the dead range from 38 to 53; and for the wounded from 270 to 300. Once order had been restored, the Soviet Union reacted to the situation with an offer of 25 million dollars worth of consumer goods to offset the worst of the shortages.

The strike set off a political struggle within the Polish Communist party which eventually ended with the return of Gomulka to power in October, 1956.10 The Party was divided into those who felt that the riots and demonstrations were the direct result of the relaxations and those who felt that further relaxations were necessary. 11 The Polish leadership decided in June that it could no longer rely on troops to maintain order and the régime. On July 6, 1956, a series of financial concessions was made to the Polish workers. 12 On August 4, 1956, negotiations were begun for Gomulka's return to power. Gomulka was a popular figure.

In the eyes of some people, he had been a martyr for the cause of Polish independence from Moscow, because of which they were willing to forgive many of his past excesses. 13 
By October, however, the situation in Poland had deteriorated to the verge of full-scale revolt and civil war. This growing chaos had not, of course, been lost upon the Polish leadership. Finally, on October 19, 1956, Gomulka was installed as First Secretary of the Polish Communist party. 14

The situation in Poland had been allowed to progress to the danger point by the paralysis of the Soviet leadership. There was no way for the Soviets to "speak with one voice."15 However, by October 19 the Soviet leadership had become concerned to the point that a delegation headed by Khrushchev and including Molotov went to Warsaw to take the situation in hand. Soviet troops were alerted for possible action. 16

The new Gomulka leadership managed to convince the Soviets that the Polish leadership was in control of the situation and that the Polish Communist party was committed to Marxism-Leninism and to close relations with the Soviet Union. They also made it clear that it was unlikely that the Polish army would obey Rokossovsky, the Sovietappointed head of the Polish armed forces. In short, the Gomulka leadership convinced the Soviets that everything was under control, the Party monopoly would be maintained, and that Poland would follow the Soviet Union in all foreign policy matters. There would be no withdrawal from the Warsaw Pact. 17 But all of this was not clear at the time.

On October 19 there was a real danger of fighting between Soviet and Polish forces. The Polish leadership had threatened to give orders for armed resistance if Soviet forces were to try to enter Warsaw itself. This threat did not end until October 22 or October 23.18 
Soviet military intervention in the Polish crisis was prevented by a Soviet fear that their intervention would spark a real war. Also, the repercussions in the West, in China, and in the Soviet Union Itself could not be known.19 On the night of October 19-20, the Soviets went back: to Moscow without reaching a complete agreement with Gomulka. Finally, on October 23, 1956, it was announced in Warsaw that Khrushchev had called Gomulka and had stated that there was nothing to prevent better relations between the two countries. 20

Gomulka's "Polish way to socialism" was based upon five factors: Gomulka's recognition of the peculiarities of the Polish nation which made the wholesale transfer of Soviet institutions counterproductive; widespread hostility to Communism among the Polish people; the specifics of the agrarian situation in Poland and the independence of the Polish peasants; the higher level of industrialization in Poland than was the case at a comparable stage in the "building of socialism" in the Soviet Union, which was an additional factor that made the strict translation of Soviet practice into Poland impractical and which further increased the attractiveness of a "separate path to socialism"; and finally, the agreement, which allowed the "solution" to function, that a close alliance between Poland and the Soviet Union would be maintained in all extra-bloc foreign affairs with the stipulation that the Poles would be free to exercise a large degree of local autonomy so long as the Party remained in power. Soviet acceptance of the "Polish path" was aided by the fact that Poland had no ideological ambitions, unlike the Yugoslavs, either within the bloc or outside of it. 21 In an address to the Polish Central Committee Gomulka criticized the abuses of the 
"personality cult" and promised the democratization of the Party, a return to legality, and criticized previous economic policy for a lack of attention to consumer goods and agriculture. He promised basic economic reforms, factory self-government, and material work incentives for the industrial workers, peasants, and artisans. Economic compulsion was rejected. 22

On November 18, 1956, the Gomulka leadership went to Moscow to regularize their relations with the Soviets. The Soviet Union agreed to cancel 2.4 billion rubles of the Polish debt to the Soviet Union and to recall Marshal Rokossovsky. Poland agreed to strictly support Soviet foreign policy and to allow the continued stationing of Soviet troops in Poland under certain conditions relating to troop disposition and movement. 23

The agreement between the Soviets and the Poles was to become the pattern for the 1956 readjustments in the bloc. Like the agreement between Czechoslovakia and the Soivet Union in 1943, and the East German settlement in 1953, the 1956 arrangement with Poland was to serve as the pattern for similar agreements with other people's democracies. 24

The Polish settlement established the critical limit for which the Soviets had been searching. Beyond that limit nationalism and deStalinization would not be allowed. The events in Hungary were proof that those limits could not be crossed with impunity.

THE HUNGARIAN CRISIS

The proximate cause of the 1956 Hungarian revolt was the power struggle between the Nagy and Rakosi factions within the Hungarlan Communist party. 25 Imre Nagy was closely associated with the Malenkov 
"New Course." Rakosi was a Stalinist hardliner, one of the Hungarian Muscovites. In early 1955 following the downfall of Malenkov, the Rakosi faction returned to power, Nagy having achieved prominence, not on his own, but only as part of the "New Course."

Rakosi's policies were unpopular and even went beyond the bounds set by the Khrushchev leadership. Rakosi's policies involved a reemphasis upon collectivization, the arrest of some kulaks (or rich peasants), and a Party purge. 26 on July 18, 1956, Rakosi was finally replaced by Erno Gero, a Hungarian Stalinist who lacked Rakosi's political "talent," amid acknowledgements of bad policies and promises for improvements. However, Gero came to power with no clear policy. Neither he nor the Soviets had formulated one. Because of this vacuum, Gero's régime rested entirely upon the organs of physical power: the secret police, the army, and the Soviet occupation forces. By late October, Gero's power was based entirely upon the Hungarian secret police. He lacked both Hungarian and Soviet support. 27

Apart from the irresolution in the Hungarian government attendant to the political turmoil, three basic elements contributed to the 1956 revolt. The first was the very bad economic situation in Hungary in 1956. The main weaknesses were the incredibly bad harvests that year, a coal shortage, and the resulting unemployment. Adding to the already bad situation were the continued deliveries of coal and other goods to the USSR in payment for previous economic aid. The second element was the Soviet underestimation of the gravity of the Hungarian situation. The last element was the situation in Poland, 28 as symbolized by the widespread discussion of it in such student-intellectual groups as the Petofi Clubs. 
On October 23, a demonstration was held in support of various student demands, known as the Sixteen Points. Among the demands were: the withdrawal of Soviet troops, free elections, a new economic policy for Hungary, freedom of the press, and new Communist party elections. The demonstration, which turned out the people of Budapest, was led by university students and factory workers. 29 The demonstration became violent, and on October 24 Soviet tanks were used to restore order. As one result of the increasing pressures upon the Gero régime, Imre Nagy was returned to the Hungarian collective leadership in early October, 1956. In late October, a Soviet delegation went to Budapest and authorized Nagy and Kadar to begin reforms. The withdrawal of Soviet forces in the near future was also promised. Thus, Nagy was placed in real power by the Soviets on October 25, 1956, in an attempt to save the Communist régime in Hungary. 30

It appears that contingency plans to use Soviet military force to "restore order" in Hungary had been made by the Soviets as early as October 23 or 24.31 Khrushchev indicated that after extensive talks with the Chinese, Marshal Ivan Konev, commander of the Warsaw Pact troops, was instructed to prepare to restore order in Hungary. Force was recognized at this stage as a possible necessity. 32 Therefore it is clear that when the Soviet troops were removed from Budapest following their functional defeat between 0ctober 24 and 27 , it was only to regroup and to be ready for a possible return. 33 This view is also reinforced by Khrushchev. The Soviet decision to pull Soviet troops out of Budapest was taken independently of Imre Nagy's requests. 34 The Nagy government as of October 27 included members who were 
non-Communists. The most notable was Bela Kovacs, who had been a leader of an opposition party prior to 1947 when he had been arrested. This created a situation which was "too fluid to be viewed with equanimity" by the Soviets. 35 On October 28, 1956, in a Pravda editorial, the Soviets set down the limit on what they would allow politically in Hungary: a more responsive government in terms of popular aspirations, but nonetheless, a solidly Communist one. There was to be no compromise with regard to the political monopoly of the Hungarian Communist party. 36 On October 30 the Soviet officials declared (see Appendix N) that they would re-examine their economic relations with Eastern Europe, recall their economic and military advisors, conduct all future relations on the basis of the strict observance of national sovereignty, and that they would renegotiate their military agreements with the various East European countries within the framework of the Warsaw Pact. 37 However, the Soviet declaration did not lessen the tension nor did it contain the events. Instead of heeding the Soviets, the Hungarians instituted a coalition government, permitted a free-press, restricted the police, asked the United Nations to exert pressure on the Soviets to remove Soviet troops, and withdrew from the Warsaw Pact while at the same time declaring Hungarian neutrality. 38

On the Soviet side, at the same time the declaration on "friendship and cooperation" was issued on October 30 , Soviet troops were already moving toward Hungary from the central Ukraine. 39 Indeed, Soviet troops were crossing into Hungary before Nagy announced Hungarian withdrawal from the Warsaw Pact. 40 On November 1 heavy Soviet reinforcements were moving into Hungary while the Soviets made denials that 
there was any intent on their part to use force. 41

The situation got out of hand because the Hungarians lacked a coherent plan of action. Had Nagy remained in control of the situation and been able or willing to follow a more moderate path, it is likely that Hungary would still have been occupied, but that the subsequent events of November 3 would not have occurred. 42 However, it is possible that rather than being unable to control the course of political events, Nagy became the leader of the Hungarian revolt. 43 Nagy's situation was, however, more complex. He was the leader of a faction which had been held together by a single issue: Rakosi. Once that issue had been removed, the coalition could not stay together. The dynamics of Nagy's group pushed it toward an "openly national Communist policy."44 At the same time, it was functionally impossible to really form any. sort of governing policy. For one thing, time was far too short.

On November 2 the Soviets decided finally upon a second military intervention. In preparation for the intervention, on November 3 a rival Hungarian government was set up and was to be "led" by Janos Kadar, who had gone over to the Soviets. On November 4 Kadar announced the formation of the new government and asked for the assistance of the Soviets to restore order. The Soviet attack began the same day. The Soviet action had the endorsement of all the other East European régimes. 45 At the end of several days, order was restored, with 2900 Hungarians dead and 13,000 wounded! Soviet losses in the action are not known. 46 Finally, on November 22 Imre Nagy and various members of his government were arrested as they left the Yugoslav Embassy where they had sought assylum. Nagy was later "tried" and executed. 47 
Brzezinski has made the following observation:

On November 4 Soviet artillery fire signaled the Soviet determination not to tolerate national Communism within the Soviet fold, while the failure of Nagy to contain the events demonstrated the inability of national Communism to maintain domestic stability in the wake of brutal Stalinism. 48

There could now be little doubt. Soviet force was the primary element which held the bloc together. In the streets of Budapest there was neither Communist ideology nor economic development, only the treaded imperative of geopolitics. 
NOTES

CHAPTER IX

$I_{\text {Khrushchev, p. } 461 .}$

2 Brzezinski, p. 206.

${ }^{3}$ Ibid., p. 202.

${ }^{4}$ Dziewanowski, pp. 208-212.

5 Ibid., p. 258.

${ }^{6}$ Ibid.

${ }^{7}$ Ibid., pp. 258-259.

${ }^{8}$ Ibid.

${ }^{9}$ Ibid., ; Dmytryshyn, pp. 291-292; and Mackintosh, pp. 155-156.

10 Dmytryshyn, pp. 291-292.

${ }^{11}$ Dziewanowski, p. 267.

12U1am, pp. 582 and 590-591; Mackintosh, p. 156.

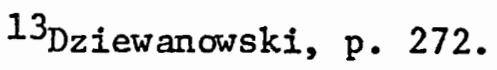

${ }^{14}$ Ulam, pp. 582 and 590-591; Mackintosh, p. 156.

15Ulam, p. 590.

16 Dmytryshyn, p. 292.

17 Brzezinski, p. 258; Ulam, p. 593. 
18Ulam, p. 591; Mackintosh; p. 163.

${ }^{19} \mathrm{Ulam}$, p. 591.

20 Mackintosh, p. 163.

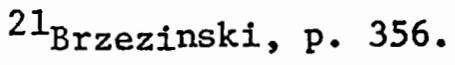

22Dziewanowski, pp. 276-277.

23 Dmytryshyn, p. 292; Ulam, p. 593.

${ }^{24}$ Ulam, p. 593.

25 The following analysis of the Hungarian revolt up to the formation of Soviet contingency plans on October 23 or October 24 follows Dmytryshyn, pp. 292-293, except where otherwise noted.

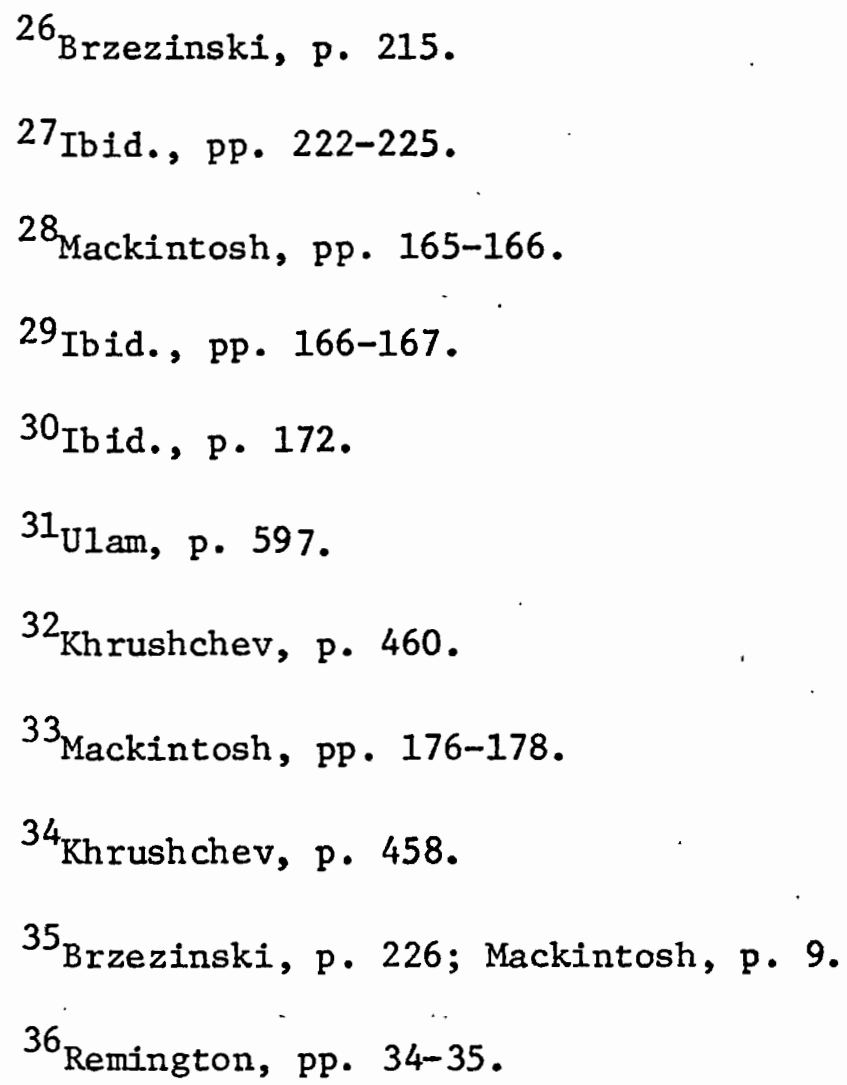

37Dmytryshyn, p. 293; Remington, p. 37. See also the "Declaration by the Government of the USSR on the Principles of Development and Further Strengthening of Friendship and Cooperation Between the Soviet Union and Other Socialist States, October 30, 1956," Pravda, October 31, 1956, in Paul E. Zinner, ed., National Communism and Popular Revolt in Eastern Europe (New York: Columbia University Press, 1956), pp. 485-489. 
${ }^{38}$ Dmytryshyn, p. 294; Ulàm, p. 596.

${ }^{39}$ Ulam, p. 596.

40Mackintosh, p. 177.

41 Ulam, p. 596.

${ }^{42}$ Ibid., p. 594 and p. 597.

43 Mackintosh, pp. 171-173.

${ }^{44}$ Brzezinski, p. 227.

45 Remington, p. 40; Khrushchev, p. 462.

46 Dmytryshyn, p. 294; Ulam, p. 596.

47Dinytryshyn, p. 294.

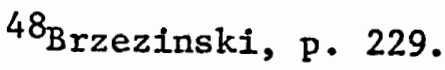




\section{CHAPTER X}

THE NEW LENINISM

"Iong live the victorious banner of our
Party -- Leninism!" -- Kh rushchev1

COMPARISONS

The Polish and Hungarian revolts had their causes in the postwar histories of the two states. Those histories were conditioned by the development of the Soviet East European system. The causes of the two revolts were deeply embedded in nationalism, in the manner in which Communist control was established, in the economic chaos brought about by the Soviet economic model, and in the senseless brutality engendered by Soviet policies. The hope for political and economic relaxation brought about by the "New Course" was frustrated by the revitalized centralism of the Soviet Union after February, 1955. The roots of the revolts must also be sought in the poorly-defined character of the Soviet de-Stalinization program. This Soviet failure, which arose from the Soviet Party power struggle, became critical following the 20th Congress of the CPSU. The warning implicit in the "Polish solution," the warning in the Pravda editorial of October 28, and the warning implicit in the declaration of October 30 were not sufficient to contain the events in Hungary. For Hungary the definition of limits to the relaxation had come too late. In fact, by the summer of 1956 , 
the time for the definition of limits had passed. It was the settlement of the Polish and Hungarian revolts the following winter which established the long overdue, explicit definition of Soviet policies in Eastern Europe.

The success of the "Polish October" was based upon the limited scope of the Polish "path" as defined by Gomulka and the Polish leadership in October, 1956. The Polish "path" was restricted to domestic affairs and was not a challenge to fundamental Soviet interests. The main elements of Gomulka's program, which enabled its success and acceptance by both Poland and the Soviet Union, were: Gomulka's past, which made of his assumption of power on October 19 an assertion of Polish nationalism; the retention of all political power in the hands of the Polish Communist party; and the Polish assertion that the reforms were domestic in nature and would not involve Poland in any sort of foreign policy independent from that of the Soviet Union. Also, it is equally important to note that the Soviet action in Hungary gave to Gomulka a meaningful ability to guide the Polish reforms and to retain Communist power as those reforms were elaborated following October 23.2 In Hungary the situation was quite different. According to his memoir, Khrushchev thought of Imre Nagy at the time of the revolt as the leader of a small "clique" which took power through the exploitation of Rakosi's errors and proceeded to overthrow the legitimate government of Hungary. Supposedly, Nagy spoke only for himself and a small group of emigrees who had returned to "help the counter-revolution."3 Similarly, the object of the Soviet military interventions was the preservation of international "fraternal proletarian solidarity" and not Soviet national goals. 4 Though the pattern of justification is clear, 
Khrushchev and the Soviet leadership must have been aware of the true dimensions of the Hungarian revolt.

The news of Soviet concessions to Polish autonomy served as an additional pressure upon the Gero and Nagy régimes. In the end, Nagy placed Hungarian national interests over those of the Soviet Union. 5 Polish concessions were not considered, only the Soviet. Soviet toleration of the Polish "October" signified a Soviet realization that a "more profitable" relationship was needed between the Soviet Union and the East European states. ${ }^{6}$ It did not signify a Soviet willingness to allow withdrawal from either international Communism or the bloc.

To dwell on the relationships between the Polish and the Hungarian revolts is misleading. Each developed along its own course with a minimal influence from the other. The events of November in Hungary served as a demonstration that the Soviets would, when pressed closely enough, use troops; but this was already known to the Polish leadership. The Polish crisis came to a head on October 19 before the Hungarian crisis. And, the Hungarian economic and political situation was critical enough that a revolt would have developed from any attempt at reform, regardless of events elsewhere.

The essential difference between the two revolts, the fundamental determinant in the decision by the Soviets to use force, was that the Polish liberalization was led and contained by the Polish Communist party, while in Hungary the Party lost all semblance of control. 7 Therefore, Khrushchev's actions in Poland can be seen roughly as an effort to cut his own domestic political losses as well as those of the Soviet Union in the hope of reasserting Soviet dominance at a later 
date. In Hungary the Soviet effort was focused upon the re-establishment of Communist control as such. ${ }^{8}$ Thus the Soviet use or threatened use of military power established the permissible limits to de-Stalinization and "national Communism."9 The limits were based upon the primacy of the Soviet Union balanced against the domestic needs of the various Communist leaderships in Eastern Europe. 10 From Communism and the bloc there could be no desertion.

\section{RECONSTRUCTION}

Following the events of October and November of 1956, the Soviet leadership set about the reconstruction of geopolitical stability in Eastern Europe and the position of the Soviet Union in that stability. The Soviets had made four principal errors which had led to the severe crisis out of which they were emerging in the later winter of 1956. These errors were: an underestimation of Tito's ambitions; an overestimation of the extent to which the "foundations of socialism" had been built in Eastern Europe, which created a further overestimation of Communist strength and an underestimation of East European hostility; the failure to comprehend the forces which acted to create a domestic focus within the various East European leaderships; and, finally, the Soviet practice of generating foreign policy for the bloc as a whole on strictly Soviet criteria. 11 These errors in judgement led to the reconciliation with Yugoslavia and to the explicit destruction of the Stalin myth. The result was the dissipation of the Stalinist unity of ideology and power in Eastern Europe.12 The development of this situation was latent within the Soviet and East European system. 
The Stalinist legacy, in the terminology of the initiated, was the mounting contradiction between the imperatives of the political superstructure and the dictates of the material and social base.13

The Stalinist interstate system was essentially political in nature. This was due to the necessity to transform the economic base of Eastern Europe along Soviet lines and to create the necessary ties to the Soviet Union. 14 While the redefined system which the Soviet leadership and Khrushchev instituted in the course of 1955 through 1957 certainly did not abandon the political instrument, the political aspect was greatly augmented by an increasing reliance upon the Comecon and the Warsaw Pact.15 In a very real sense, the redefinition of the system began with the Soviet declaration of October 30 th. 16 The end result of the process was the replacement of the Stalinist, totalitarian system with what came to be called the socialist commonwealth: a group of allied, totalitarian states containing the seeds of pluralism and, at the same time, which acknowledged Soviet leadership.17

The formal control mechanisms which emerged as central elements in the redefined system were: the Warsaw Pact, the Comecon, the Institute for Nuclear Research and other such technical and scientific research institutions, bilateral treaties of friendship and mutual trade, bilateral treaties regarding the stationing of Soviet. troops in Eastern Europe which augmented the provisions of the Warsaw Pact, bilateral trade treaties which augmented the Comecon and which involved coordinated but not integrated economic planning, and cultural and mass media co-operation. 18 It should be noted that each of these functions had counterparts in classic Stalinism.

In terms of extrabloc foreign policy, Khrushchev moved away from 
the position of continual military struggle and confrontation and adopted the policy of "peaceful co-existence" which had been set in motion by the "New Course."19 However, the "basic legitimacy of nonCommunist régimes" was "still not accepted."20

In terms of intrabloc diplomacy, a great deal of regularization of basic diplomatic channels and consular conventions took place in 1957 and 1958. The roles of the Soviet ambassadors to Hungary, Poland, Rumania, and East Germany as direct superiors for the domestic leaderships of these countries decreased. 21

Writing in 1961, Brzezinski identified six major points of contrast between the Stalinist era and the period that followed. The postStalin era was: most evidently, not as politically monolithic and invulnerable to change; better equipped to absorb strain; more vulnerable to ideological erosion; characterized by growing evidence of the SinoSoviet conflict; the transformation of the national empire of the Soviet Union in Eastern Europe into an international Commmist empire; and a growing reliance on political and economic ties to cement the unity of the East European bloc. 22 Thus, in most respects, the major contrasts between the Stalinist era and what followed it were a matter of degree: the end result of the confrontation between the unworkable or counterproductive policies of classic Stalinism and the geopolitical and economic realities of the middle and late 1950s. The major areas in which that confrontation and the Soviet and East European redefinitions were hammered out were political, economic, and military. In each case, the Soviet leadership was able, to a greater or lesser degree, to reassert the central and primary position of the Soviet Union and the CPSU. 
The explicit political reconstruction began with the Soviet declaration of October 30, 1956, and was followed in November with the Suslov formula. The main elements of that formula were: the maintenance of the political monopoly of the various Communist parties within their respective states, the strengthening of the ties between the proletariat and the peasantry, socialist ownership of the means of production, and the resolute defense of the gains made by the "revolution."23

The Suslov formula was supplemented and further elaborated by the Chinese declaration of December 29, 1956, which set forth a program for the restoration of bloc unity. The main elements of the Chinese program were: political and ideological unity with an allowance made for local diversity, the maintenance of the dictatorship of the proletariat, the maintenance of proletarian internationalism, and the assertion of the primacy of the Soviet Union. 24

Throughout 1957, East European Communism and the position of the Soviet Union in the bloc was repaired largely along the lines of the Chinese declaration. The Soviets asserted the primacy of the CPSU and the Soviet Union within the structure of proletarian internationalism. The internal and external struggle against imperialism and the Communist political monopoly were reaffirmed. And, the "either-or" monolithic unity of the classic stalinist era was replaced by a degree of diversity within the bloc. 25

From November, 1956, to April, 1957, a series of bilateral meetings was held between the Soviets and the East European leaderships. These meetings reaffirmed the loyalty of the East Europeans to the Soviet Inion and the CPSU. The Soviets on their part made adjustments in the 
character of their economic and military relations with Eastern Europe. The supply of raw materials and foodstuffs was increased, various loans and grants were made, and various debts were canceled. The status of Soviet troops stationed in Eastern Europe was regularized. 26

In addition, Khrushchev called a meeting of the East European parties which took place on January 1, 1957, in Budapest. The meeting was between Hungary, Rumania, Czechoslovakia, Bulgaria, Albania, and the Soviet Union; Poland did not attend. The conference issued a communique proclaiming the unshakable unity of the Soviet bloc and affirming the Soviet view of the Hungarian revolt. 27

A further interesting facet of the reconstruction of the Soviet position in Eastern Europe was the reminders made by the Soviets that Stalin had not been entirely without merit. As early as November, 1956, favorable references to Stalin appeared in various official Soviet statements. In January, 1957, while in China, Khrushchev mentioned that Stalin had known how to deal with the enemies of Communism. 28 These statements were in keeping with the position taken by Khrushchev in the "secret speech." It had been in the "ideological fight" with the "Trotskyites, rightists, and bourgeois nationalists" that Stalin had "played a positive role." 29

The completion of the political reconstruction of the bloc took place at the November, 1957, celebration in Moscow of the fortleth anniversary of the Russian Revolution. At that meeting the "state ruling" parties reaffirmed the re-instated principles of international Party discipline. 30 The meeting's declaration (see Appendix 0) set out the parameters for political unity. It affirmed the Soviet doctrine 
of peaceful co-existence; set down that both revisionism (defined generally as right-wing opportunism and a manifestation of bourgeois ideology) and dogmatism (the refusal to take the objective situation into account in decision-making) must be overcome; and stated that each Party was to decide for itself which danger was the greater for it as the situation arose. 31

The declaration made a seven-point definition of revisionism. Revisionism: declares that Marxism-Leninism is obsolete as a guide for social development; tries to undermine the faith of the workers in Marxism; denies the historical necessity of the proletarian revolution and the dictatorship of the proletariat; denies the leading role of the Communist parties in that revolution; denies proletarian internationalism; attempts to abandon Leninist norms in Party relations, especially the principle of democratic centralism; and tries to convert the Communist party into an organization little better than a debating club. 32 The declaration also emphasized the danger of factionalism, while stating that the forms of the transition to socialism in specific countries may vary. It also set down that the revolution could proceed through parliamentary means, provided those means were turned to the purposes of the revolution. However, the use of violence was not entirely ruled out. The declaration also called for "unity of action" on any problems which might face the bloc. 33

The declaration also reaffirmed the maximum Soviet goal. It stated that the objective of the Communist and Worker's parties was the victory of the revolution "for the cause of peace, democracy and socialism on a world scale." 34 
At the celebration, the Chinese were firmly behind the Soviet centralist position. The Polish Party was alone in its opposition to the Soviet line. ${ }^{35}$ However, Poland was retained in the bloc due to a concession made by Gomulka which "implied" a "recognition that there were higher considerations than the peculiar requirements of the construction of socialism in Poland."36 The conference, therefore, defined for Poland and Gomulka the fine line which divided loyalty to the Soviet Union and to Communism from treason. 37 By making that definition for Poland, the definition was also made for the rest of the Soviet bloc. It should be noted in addition that the meeting established Gomulka's formal subservience to bloc unity. 38 Despite Khrushchev's desires, Yugoslavia chose to remain outside the newly reformed carm.39 The Yugoslavs did not sign the declaration. 40

The re-establishment of bloc unity had been, for the time being, completed. It was symptomatic that the campaign against Yugoslavia was renewed; an independent, uncriticized Yugoslavia could not be tolerated either by the Soviet Union or by China. By 1958, out of fear of the implications of friendly relations with Yugoslavia, the Chinese resumed the attack upon Yugoslavia. They were joined by the Soviets. The 1948 Cominform anti-Tito declaration was in its own tum "rehabilitated." However, there was no return to the extremes of Stalin's anti-Tito campaign; the 1948 economic blockade was not repeated. 41

Regarding the declaration of the November, 1957, Moscow celebration, this observation has been made: 
- . any progress from Stalin's handling of the satellites was more apparent than real. The crucial

point was that the camp declaration re-established the priority of the parties over the governments. 42

Thus the Soviet Union, despite the events of 1956 and the introduction of a certain degree of flexibility, was able successfully to reassert its central position, the leading role of the Soviet Union and of the CPSU. 
NOTES

CHAPTER X

$I_{\text {Khrushchev, "Speech," p. } 677 .}$

2Brzezinski, pp. 259-261; see also Dziewanowski, pp. 279-280.

$3_{\text {Khrushchev; p. } 458 .}$

${ }^{4}$ Ibid., p. 459.

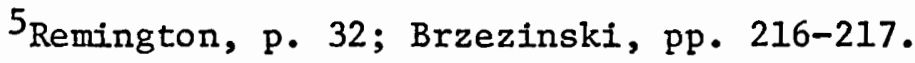

${ }^{6}$ Brzezinski, p. 262.

7Mackintosh, p. 158.

${ }^{8}$ Ibid., p. 164.

9 Those limits were to result in the identity of acceptable "national Communism" as practiced in Poland and "separate paths to socialism."

10 Brzezinski, pp. 263 and 269.

${ }^{11}$ Ibid., pp. 263-264.

${ }^{12}$ Ibid. , pp. 153-154.

${ }^{13}$ Ibid., pp 138.

${ }^{14}$ Ibid., p. 106.

${ }^{15_{\text {Wolfe, }}}$ p. 3 .

16 Kaser, p. 76. 
${ }^{17}$ Ibid., p. 302.

${ }^{18}$ Ibid., pp. 446-460.

${ }^{19}$ Schwartz, p. 112.

${ }^{20}$ Ibid., p. 116.

$21_{\text {Brzezinski, pp. } 469-470 .}$.

22Ibid., pp. 477-479.

23 Ibid., p. 273.

${ }^{24}$ Ibid., pp. 277-282.

${ }^{25}$ Ibid.

${ }^{26}$ Mackintosh, pp. 193-195.

27Ibid., pp. 192-193.

${ }^{28}$ Ulam, p. 599.

${ }^{29}$ Khrushchev, "Speech," p. 19.

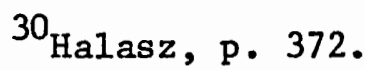

31 "Declaration of the Conference of Representatives of Communist and Workers' Parties of Socialist Countries, Moscow, November, 1957," in The Current Digest of the Soviet Press 9 (January 1958): 4-7, in Robert V. Daniels, ed., A Documentary History of Communism (New York: Random House, 1960), vol. 2, pp. 270-273.

32 Ibid.

${ }^{33}$ Ibid.

${ }^{34}$ Ibid.

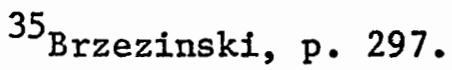

${ }^{36}$ Ibid., p. 300.

37 Ibid.
${ }^{38}$ Ibid., pp. 462-463.

${ }^{39}$ Halasz, pp. 372-373.

40 Brzezinski, p. 300 .

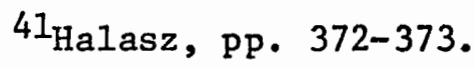

${ }^{42}$ Ibid., p. 375. 


\title{
CHAPTER XI
}

\section{INTEGRATION}

\begin{abstract}
"The goal of our foreign policy hasn't been to enrich our own state at the expense of other states; we have never believed in the exploitation of man by man, of state by state. On the contrary, both by our stated policies and by our deeds we have encouraged countries to enjoy the fruits of their own labor." -- Khrushchev. 1
\end{abstract}

\section{ECONOMICS}

After 1957, economic integration and the Soviet and East European collective security system were to carry the principal burden of Soviet and East European integration and ultimate unity. The re-establishment of the Soviet centralist position had not been so complete as to eliminate the vulnerability of Soviet ideological and political control. Khrushchev set about the attempt to counter that vulnerability through increased economic and military integration. 2

The immediate problem was the economic situation in Hungary and Poland. The Comecon countries acted to provide funds to Hungary and Poland. In 1956 and 1957 Hungary received 305.74 million dollars in credits, including 50 million from China. The Soviet Union also canceled the outstanding Hungarian debt from its purchase of the Soviet shares of the Soviet-Hungarian joint stock companies and put a moratorium on Hungarian debt service payments to the Soviet Union and Czechoslovakia. 3 
Funds were also channeled to Poland. In consideration of the 900 million dollars gained by the Soviet Union from the terms of trade established for Polish coal from 1946 through 1953, 528 million dollars of the Polish debt to the Soviet Union was canceled. In addition, Poland received 113 million dollars in loans from East Germany and Czechoslovakia. There was also a relaxation in the growth rate set forth in the Polish economic plan. 4

In line with Khrushchev's policies, Comecon took up the issue of economic planning. The 1956 and 1957 sessions of the Comecon council established that planning beyond the normal five-year period was necessary.5 In 1957 it was announced that Soviet and East European economic plans were to be coordinated. 6 The June, 1957, session and the January, 1958, session of Comecon set up specialization commissions for the specialization and standardization of products and the coordination of economic plans for the coming 15 -year period. ${ }^{7}$ The coordination of economic plans did present some difficulties. Under Comecon's founding rules, economic integration based exclusively on a centralist procedure was precluded. Further, there were no operative economic criteria which were independent of the authority of national leaders and by which national interests could be measured against extra-national interests. 8 However, the main obstacle to economic integration was, and has continued to be, the inability to harmonize the various forms of central economic planning operative in the bloc. 9 The problem was due to the fact that although prior to 1956 each East European economic plan was modeled after the Soviet plan,10 since 1956 the members of Comecon had becone increasingly autonomous. 11 Until 1956, the role of the Soviet Union was decisive in Comecon.12 After 
that date, however, the situation began to change. This is indicated by the fact that from June, 1954, until 1962, all sessions of the Comecon council were held in capitals other than Moscow.13

Though by 1957 the role of Comecon had grown, the organization had not displaced bilateral mechanisms. Technical aid projects proceeded on a bilateral basis, as well as the coordination of specific economic plans between states.14 In 1957, the first bilateral ventures began between Comecon members exclusive of the Soviet Union. East Germany and Poland laid the foundations for "decentralized" technical and administrative relations between Comecon members. 15

In sum, up to 1957, only in the area of transportation was extensive, bloc-wide cooperation achieved.16 Not until 1960 did economic integration as a function of Comecon begin to take hold in Eastern Europe. It was, after all, only in 1960 that Comecon received an explicit charter. 17

\section{COLIECTIVE SECURITY}

Khrushchev considered the Warsaw Pact a valuable instrument of socialist consolidation. 18 The role of the Soviet military presence in Eastern Europe was, and still is, to facilitate the adoption of Soviet military organizational forms and field doctrine, to aid the standardization of weaponry and weapons production, and to guarantee the existence of a political atmosphere in line with Soviet interests. 19 Brzezinski has summarized the function of the Warsaw Pact within this framework:

The political importance of the WTO is that (1) it provides a formal framework binding the various states together, 
(2) supplies the juridical basis for limiting the exercise of their sovereignty, and (3) serves as a useful forum for the articulation of unanimity, expressing ritualistically the bloc's support of Soviet foreign policy initiatives. 20

Therefore, the Warsaw Pact developed into the central institution of the Soviet and East European collective security system.

Even though the Warsaw Pact as such played a very limited role in the Polish and Hungarian crises of 1956,21 it was directly affected by the Soviet redefinition of intra-bloc relations and the reassertion of Soviet primacy. In the course of the Hungarian crisis, the Soviet Union established that Soviet troops could be withdrawn from a Warsaw Treaty state only upon the agreement of all member states and that of the state in which the troops were stationed. 22 The Hungarian crisis also gave rise to a series of Soviet and East European bilateral treaties which augmented the Pact itself. Beginning in December, 1956, and continuing until May, 1957; the Soviet Union and Poland, East Germany, Rumania, and Hungary completed the series of agreements. The Polish treaty was the first and set the pattern for the rest. This treaty contained four major provisions: an agreement that Soviet troops in Poland did not impair Polish sovereignty and were not to interfere with internal Polish affairs; a definition of the number of Soviet troops to be stationed in Poland; a provision concerning legal aid with regard to the prosecution of crimes and misdemeanors committed by Soviet troops stationed in Poland; and an explicit definition of the conditions for the movement of Soviet men and materiel through Polish territory.

The crux of the treaty was that it made Polish consent mandatory for troop movement, training, and maneuvers outside the base area. A joint Soviet-Polish commission was set up in Warsaw to settle any disputes arising under the treaty. 23 
As an instrument of military integration, the Warsaw Pact grew in importance with Soviet realization of the gains to be derived from consistent military integration and developed upon the augmented nature of the Pact provided by the 1957 status of force agreements and upon the "comradely bonds" developed through joint military maneuvers. 24 The Warsaw Pact became one of the major institutions holding the bloc together in the face of the necessary Soviet tolerance of East European national interests. 25 The Warsaw Pact has also taken on a more political character as the East European states have become less subject to detailed Soviet diktat. 26 The Pact functions in the interests of the East European régimes in that it underwrites those régimes and safeguards their frontiers. 27 In short, if the Warsaw Pact serves Soviet interests, it serves East European interests as well. 
NOTES

CHAPTER XI

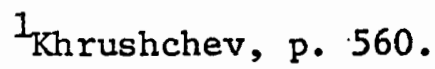

2 Remington, p. 37.

$3_{\text {Kaser, p. } 70 .}$

${ }^{4}$ Ibid.

${ }^{5}$ Ibid., p. 69.

$6_{\text {Brzezinski, p. } 284 .}$

$7_{\text {Willis, }}$ p. 301.

$8_{\text {Kaser, pp. 25-26. }}$

${ }^{9}$ Ibid., p. 5.

10 Mellor, p. 95.

$11_{\text {Kaser, p. }} 1$.

12Ibid., p. 2.

13 Harry Trend, "Comecon's Organizational Structure," Radio Free Europe RAD Background Report/138 (Eastern Europe), October 7, 1975, p. 31 .

${ }^{14}$ Spulber, p. 431.

${ }^{15}$ Kaser, pp. $70-71$.

${ }^{16}$ Spulber, p. 13.

17 Kaser, p. 39. Trend also makes the assertion that Comecon had little economic significance in the early 1950s, and that it was only after 1960 that the organization became the central institution of Soviet and East European econonic integration. See Trend, p. 3. 
18 Remington, p. 168.

${ }^{19}$ Senate Study, pp. $747-768$ and 757.

20 Brzezinski, pp. 447-448.

$21_{\text {Remington, p. } 185 .}$

${ }^{22}$ Ibid., p. 34.

${ }^{23}$ Ibid., p. 38.

${ }^{24}$ Senate Study, p. 757.

$25_{\text {Ibid., p. } 748 .}$

${ }^{26}$ Ibid.

${ }^{27}$ Ibid. 
CHAPTER XII

THE DYNAMICS OF CONTINUITY

". - Allow me to thank you for the confidence you have shown me."

-- Stalin'

\section{CONTINUITIES}

History is a continuous rather than a discrete phenomenon. Each new period builds upon the foundations set down by the choices and conditions of those which went before it. The clarity of historical definition is the product of rigorous historical analysis rather than of the historical process itself. In the development of the Soviet and East European system from the period of its active foundation, which took place from 1939 to 1948, until the narrowly defined current period, there have been seven crucial events. The first was the death of Stalin which allowed the exploration and implementation of vital reforms. The second was the realization by the Soviet leadership in 1953 or 1954 that nuclear war on a global scale was not a policy option. The third was the de-Stalinization speech by Khrushchev at the 20 th Party Congress which destroyed the continuity of Stalin's image as a symbol of unity at a time when such a symbol was most necessary. The fourth was the crisis of 1956-1957 which resulted in the redefinition of the Soviet centralist position and established the limits of East European nationalism. The fifth was the emergence of Yugoslavia and China as competitors with the Soviet Union for leadership of international Communism. 
The sixth was the removal of. Khrushchev from office in 1964 which demonstrated that there were limits upon the amount of power which could be concentrated in the hands of a single member of the Soviet leadership. And finally, the invasion of Czechoslovakia in 1968 which again demonstrated Soviet willingness to use military force as a last resort in the maintenance of bloc unity. In its own way, each of these events points to fundamental change and to a more fundamental continuity.

The death of Stalin allowed many reforms to be tried which could not have been attempted while he was alive. However, none of the reforms seriously threatened the foundations of Soviet power in Eastern Europe. The fundamental elements of the system which Stalin had set in place remained there. The reforms were a matter of degree--an effort to prevent the explosion of the system.

The realities of neclear, war may have forced the Soviets to abandon global war as a revolutionary instrument, but the ideological struggle continues, and proxy wars still occur. The maximum goal of Marxism-Leninism has not been abandoned. Only the extreme method has been redefined.

The de-Stalinization speech at the 20 th Party Congress may have destroyed the continuity of Stalin's image as a symbol of unity within Communism, but the functions which that symbol performed were transferred to other institutions such as Comecon, the Warsaw Pact, and the CPSU itself. Also, in his own slow, cautious turn, Stalin is being rehabilitated. It must also be noted that Khrushchev's use of de-Stalinization as one method to consolidate his own power is very characteristic of the system itself. In a very general way, Stalin's "Stalin" was Trotsky. 
The cristis of 1956-1957. led to the necessary regularization and reform of a system which was in need of an overhaul. The "New Course" had failed to provide the necessary redefinitions required for bloc stability. The November, 1957, declaration firmly re-established the unquestionable nature of the Soviet position at the center of the East European bloc. The 1968 invasion of Czechoslovakia further reenforced that position.

The removal of Khrushchev from office was a demonstration that the leadership of the CPSU would no longer allow the over-concentration of power in the hands of a single individual. Stalin maintained his power by setting one faction against another. Following Stalin's death, Khrushchev rose to power through participation in factions which won and by building his own faction. The crucial distinction is that, generally, Stalin manipulated factions while remaining outside of them, while Beria, Malenkov, Khrushchev, and Brezhnev were, or . are, very much members of factions.

Yugoslavia has emerged as one competitor with the Soviet Union for the leadership of international Communism, particularly in the underdeveloped and "neutral" areas of the world. However, that challenge relative to the Soviet East European bloc was firmly turned aside in 1957 and 1958. A second challenge came from China. The Chinese challenge has increased the value of the East European states and therefore indirectly allowed them more room in which to maneuver with regard to the Soviet Union. The influence of China within the bloc has not become decisive, but it is quite real. Indeed, it could be argued that the extrabloc challenge from China has made the Soviet 
Union more flexible in its policies in order to maintain bloc unity. However, the Soviet Union's influence in the bloc remains decisive in the final analysis.

Though a detailed analysis of these brief examples remains beyond the scope and competence of this work, two more detailed examples, based upon the above, are in order.

Following the purge of Beria in June, 1953, and the "resignation" of Malenkov on February 8, 1955, Khrushchev emerged as the central figure in the Soviet leadership. His position was challenged in June, 1957, by Malenkov, Molotov, Kaganovich, and Saburov. However, with the aid of Marshal Zhukov and at the end of a week of bitter struggle in the Central Committee, Khrushchev prevailed. Malenkov, Molotov, Kaganovich, and Saburov were dismissed from their posts in the government and the Party. 2

In a resolution of the Central Committee made on June 27, 1957, titled "On the Anti-Party Group of G. M. Malenkov, L. M. Kaganovich, and V. M. Molotov," the anti-Party group was accused of the obstruction of the Party's work as set out by the 20th Party. Congress. Molotov was singled out for opposition to the "virgin lands" program and for opposition to better relations with Yugoslavia. 3

Late in October, 1957, Zhukov was also stripped of his authority, and on March 27, 1958, Khrushchev replaced Bulganin as Chairman of the Council of Ministers. Thus, Khrushchev became both head of the government and head of the Party. 4

That de-Stalinization was one of Khrushchev's political weapons is further evidenced by the events of the 22nd Party Congress held in 
1961. At that congress, Khrushchev publicly launched a frontal assault upon Stalin's image. However, Khrushchev also moved against Stalin's "chief" accomplices: Molotov, Kaganovich, Malenkov, and Voroshilov.5

Since Khrushchev's removal in 1964, there has been a partial return to many of the characteristic practices of the stalin era. ${ }^{6}$ It is interesting to note that on December 21, 1969, for the first time since 1955, Pravda celebrated the anniversary of Stalin's birth.7

Thus de-Stalinization, like Trotskyism, has become a consistent political weapon.

The second example of continuity is from the area of bloc integration. Khrushchev's consolidation of power and reassertion of the Soviet position made it possible for the Soviet Union to "respond with greater energy to the problems of unity." 8 The Warsaw Pact and the Comecon became the central instruments of suppressing East European domesticism ${ }^{9}$ and hence of promoting bloc unity. Though the members of Comecon have become more autonomous since 1956, the role of the Soviet Union remains decisive. Given the relative economic strength of the organization's members, the unanimity required for a Comecon decision is "meaningless."10 However, this does not mean that the Comecon is a mere rubber stamp. Genuine disputes do develop. II Though the Comecon is not a rubber stamp, the role of the Soviet Union is decisive.12 In 1961, Brzezinski made the following judgement:

At the present time, CEMA is doubtless the single most important organ for actively shaping policies designed to promote the camp's unity.

The functions of Comecon have been developed to - . mold a 'world socialist market' as the basis for the camp's political and ideological unity. 13 
M. Lesechko, Deputy Chairman of the USSR Council of Ministers and permanent Soviet representative in Comecon, in an article titled "Stages of Comecon Economic Integration" published in Kommunist in the latter . half of 1975, outlined in summary fashion the program adopted by the 29 th Session of Comecon held in Budapest in June, 1975, to promote the economic integration of the Soviet Union and the East European satellite states. (The full text of Lesechko's article is included as Appendix P.) The members of Comecon agreed to the joint construction of "large economic projects" in the areas of fuel, raw-materials, and power generation. Agreements have also been reached in the areas of production cooperation and joint scientific and technological research and development projects. Further, the coordination of economic planning for the period 1976-1980 has been established with a central objective being the elimination of economic universalism as a further spur to integration, while at the same time securing the independence of the bloc in terms of fuel and raw-materials. Various capital investment, transportation and distribution projects have been undertaken to implement these objectives under the Agreed Plan for Multilateral Integration Measures for 1976-1980. This current, agreed plan is seen, of course, as simply one stage in the implementation of the Comprehensive Program for Socialist Economic Integration.

Coordination of economic development plans as the main method for the organization of cooperation and advancement of international socialist division of labor is becoming increasingly established as the basis for the agreed development of the economies of the fraternal countries. Plans for the new five-year period are being dove-tailed to accomplish the tasks laid down by the Comprehensive Program for Socialist Economic Integration. 14 
The salient point regarding the program adopted by the 29th Session of Comecon is that, though the Comecon presents itself as open to trade and economic agreements outside of itself, a major objective remains basic economic self-sufficiency for the bloc as a whole. This in turn is a reflection of the classic Stalinist concepts of economic autarky and the basic division of the world market now more fully developed and expanded to apply to the entire bloc. Thus Comecon has developed as the central organ of economic integration.

The Warsaw Pact, on the other hand, is the single, most important interstate organization binding together the bloc. ${ }^{15}$ The critical distinction is that Comecon operates within a framework secured through the operation of the Warsaw Pact. Comecon is important in terms of the generation of bloc policy, while the Warsaw Pact is at the core of the Soviet and East European collective security system and responsible for the final enforcement of bloc policy.

In October, 1961, the Warsaw Pact held its first well-publicized joint maneuvers. Khrushchev in this period increasingly came to view the Warsaw Pact as an instrument of bloc integration. Up to 1961, Comecon had largely failed in this regard; the Warsaw Pact was viewed as capable of generating political solidarity. 16 However, in 1966 it appeared that the Warsaw Pact's Political Consultative Committee had been unable to generate political unity, or to counter the more nationalIstic policies of the East Europeans which had begun to develop in the early 1960s. 17

In 1966 it appeared that the statements of the 23rd Party Congress held in March, 1966, regarding "equality and independence, non-inter- 
ference in each others' internal affairs, mutual support and international solidarity" as the bases of intrabloc relations were not "hollow words:" It appeared that the Soviet Union was prepared to accept the increased nationalism and resulting independence of the bloc states. By doing so, the Soviet Union was considered to be attempting to preserve the unity of the bloc and the military and political effectiveness of the Warsaw Pact. ${ }^{18}$

The source of this apparent shift in attitude can be found in the Sino-Soviet conflict. That conflict served to increase the Soviet's need for East European support and, therefore, has increased the maneuverability of the East European governments.19

In earlier periods, the East German uprising and the Hungarian revolt demonstrated that the Soviet Union would use military power to enforce its controls in Eastern Europe. 20 The invasion of Czechoslovakia in 1968 was to make this point all over again. The conflict with China notwithstanding, there were limits beyond which the Soviet Union would not allow East European nationalism to go.21 The immediate Soviet motive for the 1968 intervention was the preservation of Communist orthodoxy, as defined by the Soviets, in Czechoslovakia. With regard to Rumania, an outwardly independent state which seeks its own way while remaining inwardly the most Stalinist of the European Communist states, the Soviet intervention served as an unsubtle warning. Just as there were limits for Czechoslovakia, there were also limits for the other bloc states, Rumania not least. of all. The continued ability of Soviet troops to hold maneuvers in Rumania and Rumania's continued membership in Comecon and the Warsaw Pact indicate that, despite the verbiage by 
both the Soviets and the Rumanians, Rumania remains within the Soviet sphere, however uncooperatively. 22

The invasion of Czechoslovakia had two principal causes. The first was the defense of the western-most extension of the Soviet and East European defense perimeter. The second was Soviet fear that the main elements of the "Prague Spring" would spread outside of Czechoslovakia, perhaps even to the Soviet Union itself. In the final analysis, the invasion can be considered to be an exercise of Soviet imperial prerogatives.23 It was the concrete definition of the limits beyond which the Soviet Union would not allow domesticism to trespass. As one result of the example made of Czechoslovakia, the Rumanians ceased their demands for more political freedom of action for their state. 24

Writing in 1961, Brzezinski asserted that the Soviets have established the principle that the political practice of one Communist state is materially relevant to another, "that each Communist state must continually refer its practice to the general practices of the camp. 25 The-subsequent development of the Warsaw Pact and the Comecon have served to support Brzezinski's contention. However, like the Comecon, the Warsaw Pact is not simply a rubber stamp for Soviet policies, though it is a principal instrument of those policies.

The multilateral character of the Warsaw Pact is underscored by Andrei Gromyko's 1974 statement that an almost causal relationship exists between the "struggle for peace and socialism" and the coordination of Pact policies. 26 This means that the East Europeans are bound to the Soviet Union and the maximum goals of Marxism-Leninism 
through the mechanism of the Warsaw Pact. It should be noted, however, that regardless of the specific social systeru of the Soviet Union and given the results of the Second World War, the security of the East European states is necessarily bound to the Soviet Union. This is, moreover, a reciprocal relationship. Also, the interests of the Party elites throughout the bloc are quite parallel. And, because their interests are parallel, their policies are parallel. Those interests are not served by the violence typical of past policies. The "socialist reconstruction" of Eastern Europe has taken on a more subtle character in recent times. 27

Currently it is not entirely clear that the Warsaw Pact and Comecon are the instruments of absolute political control which they once were, legitimizing Soviet control ideologically and providing the necessary support to maintain the East European Communist régimes in power. Though this situation is not clearly the case, it is equally not clearly the case that the Warsaw Pact and Comecon have developed into organizations which function in accord with the provisions of their charters and stated purposes. Though recent developments "may point in that direction," it remains an open question. 28

A vital distinction must be made between the genuine evolution of the Soviet system as it operates in Eastern Europe and the changes which may have taken place in that complex structure of relationships under the pressures of the Sino-Soviet conflict, the Soviet pblicy of "détente" with the West, and the evident need for further economic reforms to increase the productive capability of the bloc as a whole. A clear distinction must be also drawn, and this is perhaps the most 
difficult, between a "relaxation" which takes place within the system and the evolution of the system. It is vital to note that none of the central, fundamental mechanisms of Soviet power in Eastern Europe have been abandoned. Those mechanisms have evolved in a multilateral direction, but they are still very much in place and quite operative.

\section{DYNAMICS}

The death of Stalin, the riots of 1953, the establishment and subsequent abandonment of the "New Course," the power struggle within the Soviet leadership, the de-Stalinization program, the attempted reconciliation with Tito, the shift from a predominantly bilateral system to a more multilateral one; and the events of October-November, 1956, taken together, constituted a three and a half year crisis for the Soviet and East European system: an East European "time of troubles." The reconstruction of the Soviet position in Eastern Europe took a full year of intense effort and in the end did not achieve the total re-establishment of the pre-1953 Soviet prerogatives. Following the events of 1956, for example, the Soviet extraction of capital from Eastern Europe at an annual rate of one billion dollars stopped. 29 Indeed, after 1956 there could be no question of a return to the extremes of classic Stalinism. History had moved too far. For the Soviets, the "task after 1956 was to establish some commonly-held ideological criteria and to forge new bonds of unity to prevent the diversity from becoming political disunity."30 The problem was the reassertion of Soviet political and economic hegemony in such a manner that the position of the Soviet Union was beyond serious question and, 
at the same time, there would be no resurgence of the highly counterproductive features of Stalinism. A balance was necessary between the centralist position of the Soviet Union and the pressures generated by East European nationalism.

That necessary equilibrium was established between late 1956 and the end of 1957. It was given concrete expression in the less exploitative economic policies of the Soviet Union, such as the cancellation of various East European financial debts and the extension of economic grants and other aid; the negotiation of the 1957 status of force agreements; and in the declaration issued at the November, 1957, Mos cow celebration. The equilibrium was based upon the primacy of the Soviet Union and the CPSU within the bloc and in extrabloc foreign affairs on the one hand and the domestic rights of the various East European states which operated within that context of Soviet primacy on the other. 31 It was, like so many other things in Soviet and East European affairs, a matter of degree, a more productive balance between the imperatives of Soviet power and the realities of Eastern Europe.

A final question, however, remains to be answered. What enabled the Soviet Union to re-establish its centralist position? However, given the geopolitical realities, the power relationships operative in Eastern Europe in 1956 and 1957, was the question ever seriously in doubt? Yes, it was. In all likelihood, had the Soviet position been weaker, had the Soviets not had some support from the rest of the bloc and, in a guarded yet functional way, from Yugoslavia, 32 the military operation in Hungary could well have proved to be counterproductive, forcing the Soviets to accept the neutrality of Hungary. This is not 
idle speculation, for if there had not been basic support for Soviet policies in the other bloc Parties, had they not been in control domestically and in support of the Soviet position, the Hungarian revolt may well have been replicated throughout the bloc. Also, if their support had not been forthcoming, the Poles may well have been able firmly to establish their individualist position at the Moscow celebration and follow a Polish version of the "Yugoslav path." The Poles, like the Yugoslavs in 1948, were united and prepared to resist. True, the Soviets could have imposed a "Carthagenian" solution to the entire question of "national Communism," but it is probable that such a policy would have cost more than it would have gained and certainly more than the course eventually adopted. On the other hand, given the history of Western attitudes toward Eastern Europe as demonstrated in 1938, the period 1945 to 1948 , and most starkly in 1956, there was little chance that the East Europeans had any tangible support outside the bloc such as Yugoslavia had had in 1948.

If this argument does not clearly demonstrate that the unity of the bloc was seriously at issue, neither can it be said that it was not. It is perfectly possible to construct an argument in favor of the position that the "national Communism" of Poland in late 1956 and early 1957, as expressed for example in Poland's refusal to attend the January, 1957, conference in Budapest, could have taken root in other bloc Parties. Under that condition, the reassertion of the Soviet centralist position would have been impossible for the time being. Therefore, it is necessary to conclude, at the very least, that the Soviet centralist position in the bloc, and in a very real way the 
ultimate unity of the bloc as a whole, were indeed at issue in 1956 and 1957.

Certainly the role of the Soviet military in the re-establishment of the Soviet position cannot be discounted. Through 1957 Hungary was a fresh, grim example of Soviet willingness to employ ultimate sanctions when Soviet interests were seriously endangered. And, predictably, there was a renewed emphasis upon Soviet military might in the first months of 1957,33 an emphasis which was not lost upon the East Europeans. But the Soviets' ability to rebuild the system upon a nakedly military basis simply did not exist. If that had.been the case, there would have been no necessity for the Soviets to negotiate the status of force agreements, hold the January, 1957, meeting in Budapest, negotiate the declaration of November, 1957, cultivate the Chinese and the Yugoslavs, or, for that matter, to issue the October 30,1956 , declaration. There was clearly a limit to what an exclusively military solution could have achieved given the political and economic price the Soviets were willing or able to pay at that particular time.

In the redefinition of the Soviet centralist position, the Soviets drew upon the inherent strength of the system. That strength was the direct and the indirect result of the operation of several factors. The most fundamental of these was the Communist commitment to industrialization, the ability of the Party to industrialize and to maintain an acceptable rate of economic development. Milovan Djilas' analysis of this point bears review.

No society or nation allows production to lag to such an extent that its existence is threatened. To lag means to die. People never die willingly; they are ready to undergo any sacrifice to overcome the difficulties which stand in the way of their economic 
production and their existence. 34

To repeat, it is not the absolute level of industrialization but the relative rate of industrialization which is crucial. Stalinism and its excesses were tolerated, in general, by East European Communists because they were "accepted as expedients and sacrifices that had to be made" in the course of industrialization within the Communist framework. 35 Within the Party, this issue was also vital. With regard to intra-Party power struggles, Djilas has asserted that it was that faction which was "the most consistent and determined" in its support of "industrialization along Communist principies" that would win. 36 The example of the Khrushchev-Malenkov contest is a case in point. The commitment to industrialization and to "socialist reconstruction" was vital. Industrialization was vital to the nation as a whole; the "socialist reconstruction" of society was vital to the Party. Radislaw Selucky has summarized this condition:

The formal and declared goal of the economy is to satisfy social needs and to foster growth of the population's living standard. The informal and primary goal of the economy is to strengthen socialist production relations and the existing political system. The formal economic goal expresses the interests of the population; the informal economic goal expresses the interests of the power elite. 37

Regardless of the specific goal involved, industrialization and further development were primary for political power.

Following Leninist and Stalinist principles, economics became a subordinant function of politics. A political and economic system was formed in which the "economic facts" were "far less important than the ideological considerations."38 Economic policy developed as an instrument of political control within the context of the ideological unity 
of the bloc. The Soviet Party was the guarantor of functional ideological unity. "Without such central power... the unity rooted in ideology could disintegrate under the impact of time, change, specific interests, and differing conditions." 39 Any loss of ideological unity threatened the political unity of the bloc and, by extension, the control of each East European Party. If the Parties were to remain in power, the ideological primacy of the Soviet Union was essential. Unlike the Yugoslav Party and the Chinese Party, the East European Parties had not come to power in their own right, but had been placed in power as a result of Soviet actions and were therefore dependent upon the Soviet Union. Individually they were not strong enough to retain power without Soviet backing. This is why Nagy was unable to control the Hungarian upheaval, and why Gomulka finally accepted the centralist position of the Soviet Union and the CPSU in November, 1957.

In the system which was developed after 1948, any economic decision was a political one, 40 and Party elites. "were reluctant to change the command system" which formed "the basis of their absolute power." 41 Indeed, as Djilas has observed, "Without industry the new class cannot consolidate its position or authority."42 But, because of the fundamentals of their legitimization, the Party elites must also produce sustained economic growth.

It was not until the early 1960s that it became clear that the continued subordination of economics to purely ideological considerations could not produce the needed results. 43 Through the 1950 s, the Stalinist economic model worked well as long as there was labor which could be transferred and capital was available for reinvestment. 44 During the 
1950s, capital grew more rapidly than the labor force; the growth in output exceeded the growth of the capital stock. But, in the 1960s, the growth of output dropped, while capital investment continued to grow; capital investment had reached a point of diminishing returns under the conditions of the operative, ideologically based economic model. 45 But, in 1957, the Stalinist economic mode, with relatively minor reforms, 46 was still able to produce the economic growth necessitated by ideology, political control, and the most fundamental stated purposes of Communism. Thus, at least as far as the Party apparats were concerned, the primacy of the Soviet Hnion was essential for the retention of their own domestic control. The economic threat to their control inherent in the rigid or semi-rigid subordination of economics to ideology and the subordination of that ideology to the dictates of Soviet power imperatives had not yet become clear.

The second source of strength upon which the Soviets drew in the reconstruction of their authority in the bloc was the ability of multilateral organizations such as the Warsaw Pact and Comecon to act as "shock absorbers" between the East Europeans and the Soviets. 47 The progressive development of multilateral organizations as instruments of bloc integration began in 1955 with the revitalization of Comecon and foundation of the Warsaw Pact. Though both of these organizations were surrounded by bilateral treaties and agreements which augmented their decisions, they provided a formal structure which, to an extent, stood between the East European states and the Soviet Union. How meaningful this intermediate structure was in the middle 1950s is hard to evaluate. Those organizations did not function in controvention 
of basic Soviet interests, but the purely exploitative character of those structures began to taper off after 1956. If Comecon and the WTO operated in support of Soviet interests, they also began to operate more clearly in the interests of the other member states. This is indicated by the fact that these bodies took on the character of organizations within which genuine negotiations take place.

The development of these institutions and the growth of the Soviet commitment to them in the course of the early and middle 1950s suggest that even though the Soviet Union retained its dominant position, that position was expressed "through a more formal institutionalized set of arrangements." 48 Those arrangements provided not only a buffer between the Soviet Union and the East European states, but also provided a greater flexibility and a broadened scope for maneuver on the part of both the Soviet Union and the East European states.

The third element was, curiously enough, the still largely operative rapprochement with Yugoslavia and, less curiously, the active support of the Chinese. The reconciliation with Tito did not actually founder until the November, 1957, Moscow celebration, by which time the support of Yugoslavia was no longer necessary or, as it developed, even desirable. During the course of the post-1956 reconstruction, both the Soviets and the East Europeans could point to the example of Yugoslavia and draw support for their separate positions. The Yugoslav example was used in a highly qualified form as a central element in the opening stages of the reconstruction as a quasi-model for bloc relationships. With the progressive re-establishment of Soviet centralism, that "model" became less and less relevant until it became an actual threat to b1oc unity, 
at which time it was again condemned.

At the time of the Moscow celebration the Chinese were firmly behind the Soviets. Unlike Yugoslavia, China signed the November, 1957, declaration. Further evidence is provided by the fact that the Chinese led the renewed attack upon the Yugoslavs in 1958. Sino-Soviet relations did not begin seriously to deteriorate until the late 1950s. Economic relations between the two states started to go bad only in late 1957.49 As for relations in general, several dates for the beginning of the rift have been advanced. The Chinese set the date for the beginning of the deterioration at 1956; the Soviets cite both 1958 and 1961.50 In any event, the Sino-Soviet rift did not come into the open until the early 1960 s, 51 by which time the Soviets had reconstructed their position in Eastern Europe.

The point is that at the critical moment, through the course of the reconstruction and particularly at the Moscow celebration, there was neither an ideological nor a geopolitical alternative for the East European Parties. The Yugoslav position was not strong enough to counter the Soviets except by a Yugoslav withdrawal from the conference; the Chinese supported the Soviets. Without a viable alternative, there was no choice for the East European Parties.

The fourth element of Soviet strength was the continued ability of the Soviet Union and the CPSU to act independently within the bloc. Though the tremiors of 1953 and the upheavals of 1956 necessitated various policy changes and procedural reforms, none of these actions seriously compromised the Soviet's ability to maneuver, to institute and abandon policies as circumstances dictated. The most serious threat in this 
regard came from within the Soviet Party itself as a necessary consequence of the internal power struggles between the Malenkov and Khrushchev factions. Indeed, the various reforms, by reducing the tensions within the bloc, finally served to strengthen the ultimate Soviet position.

\section{CONCLUSIONS}

It is necessary to conclude, therefore, that the resolution of the 1953-1956 crisis set in place a redefined Soviet and East European system which in its continuities with the pre-1953 system is more striking and important than in its divergencies. Though, from an East European viewpoint, the most blatant and objectionable aspects of Soviet primacy had been cancelled, having been realized as counter-productive to the bloc as a whole and finally to purely Soviet interests, in 1957 the bloc was firmly in Soviet control.

In that redefined system, the central elements of the pre-1953 system, which were the sources of its strength, re-emerged in new forms. The previous bilateral institutions and methods, though hardly abandoned, had been reconstructed in a multilateral mode. For example, the bilateral collective security network was restated in a multilateral form-the Warsaw Pact, which was augmented by bilateral treaties. And, the pre-1953 multilateral institutions were either abandoned where they proved no longer practical or were revitalized and given a real function. Many of those factors which allowed the Soviet Union and the CPSU to resolve the crisis more nearly in line with their desires had formed part of the basis for the pre-1953 system. Those factors were: a functional Western indifference toward Eastern Europe, or the inability 
of the West to act decisively on behalf of the strictly East European states; the Communist commitment to industrialization and economic growth; the economic and ideological dependence of the East European states upon the Soviet Union; and, finally, the ability of the Soviet Union both to resolve its own internal power struggle and to retain through the course of the crisis its flexibility of maneuver with regard to its East European political and economic policies.

There can be no doubt that the 1953-1956 crisis was real. The sources of that crisis can be found in the weaknesses of the pre-1953 Soviet and East European system; but the resolution of that crisis had its sources in the strengths of that same system. 


\section{NOTES}

CHAPTER XII

\footnotetext{
${ }^{1}$ Stalin, "Stalin's 'Election Speech'," in Dmytryshyn, p. 459. ${ }^{2}$ Dmytryshyn, pp. 269-270.
}

${ }^{3}$ Central Committee of the Communist Party of the Soviet Union, "On the Anti-Party Group of G. M. Malenkov, L. M. Kaganovich, and V. M. Molotov, June 29, 1957," in The Current Digest of the Soviet Press 9 (July 1957): 264-267 in Robert V. Daniels, ed., A Documentary History of Communism, 2 vols. (New York: Random House, 1960), vol. 2, pp. 264267 .

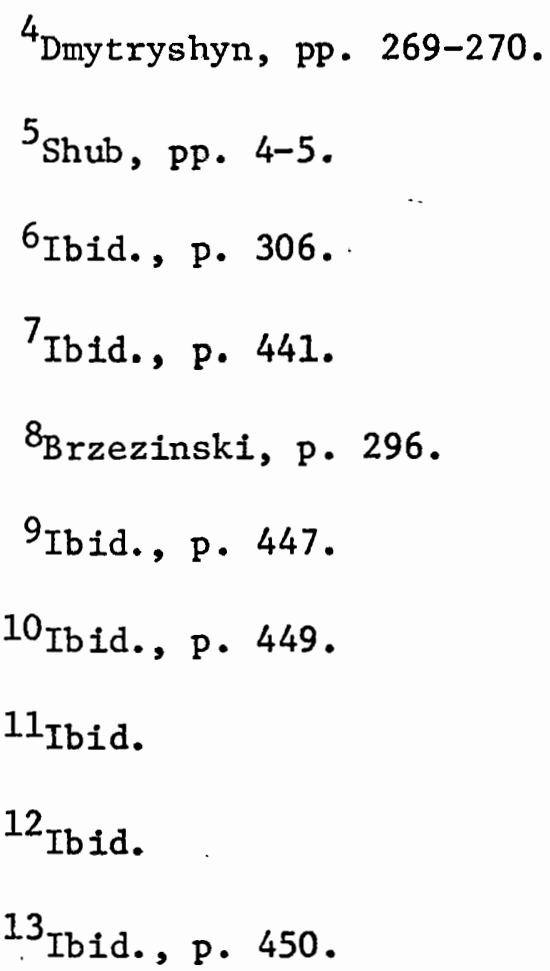

${ }^{14}$ M. Lesechko, "Stages of Comecon Economic Integration," Kommunist No. 16 (1975), in Reprints from the Soviet Press 22 (January 1976): 45-55. A detailed analysis of either the Comprehensive Program for Socialist Economic Integration or the Agreed Plan for Multilateral Integration Measures for 1976-1980 are beyond the scope of this work. 
${ }^{16}$ Wolfe, pp. 150-151.

${ }^{17}$ Senate Study, pp. 759-760.

${ }^{18}$ Ibid., p. 765.

${ }^{19}$ Remington, pp. 167-168; Senate Study, pp. 767-768.

$20_{\text {Wolfe, }}$ p. 81.

${ }^{21}$ A detailed study of the "Prague Spring" and the invasion of Czechoslovakia are beyond the scope of this work.

${ }^{22}$ See E. J. Czerwinski and Jaroslaw Piekalkiewicz, eds., The Soviet Invasion of Czechoslovakia: Its Effects on Eastern Europe (New York: Praeger, 1972); and I. William Zartman, ed., Czechoslovakia, Intervention and Impact (New York: New York University Press, 1970).

${ }^{23}$ Shub, pp. 416-418.

24 Ulam, p. 745.

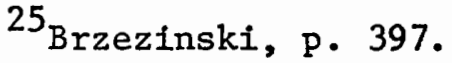

${ }^{26}$ Lawrence T. Caldwe11, "The Warsaw Pact: Directions of Change," Problems of Conmunism 24 (October 1975): 1.

${ }^{27}$ Ibid., pp. 18-19.

${ }^{28}$ Ibid., p. 19.

${ }^{29}$ Brzezinski, p. 283.

${ }^{30}$ Ibid., pp. 264-265.

${ }^{31}$ Ibid., p. 263.

${ }^{32}$ See Khrushchev Remembers, pp. 461-464. Khrushchev asserts that not only was Tito in agreement that a Soviet military intervention was called for, but that "The leaders of the fratemal Socialist countries were unanimous: we had to act, and we had to act swiftly." The Bulgarians and the Rumanians went so far as to offer military aid to "the revolutionary workers of Hungary." The offer was refused amid some joking about Rumanian participation in the crushing of the 1919 
Hungarian Communist revolution. If what Khrushchev asserts is accurate, there would seem to have been a genuine fear on the part of other bloc Party leaderships that the Hungarian revolt was in imminent danger of spreading.

$$
\begin{aligned}
& 33 \text { Mackintosh, p. } 199 . \\
& { }^{34} \text { Djilas, The New Class, p. } 12 . \\
& { }^{35} \text { Djilas, The Unperfect Society, pp. 102-103. } \\
& { }^{36} \text { Djilas, The New Class, p. } 28 .
\end{aligned}
$$

${ }^{37}$ Selucky, p. 21. This duality of economic goals is the economic parallel of the formal and informal structures of political power in such political systems; the duality of political power being the formalities of the governmental structure as opposed to the power of the single Party which controls that structure.

$$
\begin{aligned}
& 38_{\text {Ibid., p. vi. }} \\
& 39_{\text {Brzezinski, p. } 398 .}
\end{aligned}
$$

${ }^{40}$ Selucky, p. 32. Selucky also explains one of the central reasons for the difficulty involved in economic reform. "As long as the subordination of economics to politics prevails and as long as any economic decision is at the same time a political one, the economic system cannot be changed on the basis of economic considerations alone." (Selucky, p. 32.) It must be noted in addition that any lack of subordination of economics to the political needs of the system would be very un-Leninist and a threat to the power of the Party.

${ }^{41}$ Ibid., p. 38 .

${ }^{42}$ Djilas, The New Class, p. 42.

${ }^{43}$ Campbe11, p. 160.

${ }^{44}$ Ibid., p. 126.

45 Ibid., p. 125. The central problem in this regard was the fact that the economy had run out of "extensive" growth opportunities and was in a position in the early 1960s which necessitated a shift to "intensive" economic growth methods. "Extensive" economic growth is characterized by the simple expansion of the labor supply and capital investments. As new opportunities are realized, the major factors of the economy are simply expanded to take advantage of them. The "intensive" growth pattem involves the more effective use of 
labor and capital resources, the application of scientific and technical innovations to economic problems, higher qualifications for the labor force in terms of training, and an improved organization of production and exchange. (Selucky, p. 4.) The most important factors for intensive growth, the pattern of a mature industrialized economy, are "daily innovations, and smooth, technological, organizational, and competitive progress." (Selucky, p. 17.) Such a condition would be a substantial threat to a Leninist Party. The result is that "the non-market model is not suited to intensive economic growth." (Selucky, p. 18.)

46 For a more complete discussion of these reforms which involved very limited measures to increase the efficiency of the strict command model on the one hand and more extensive reforms winch were an extremely circumspect attempt to introduce some market economic techniques, see Selucky, pp. 34-35.

$$
\begin{aligned}
& 47_{\text {Brzezinski, pp. } 406-407 .} \\
& 48_{\text {Ibid., pp. } 459-460 .} \\
& 49_{\text {Kaser, p. } 84 .} \\
& 50_{\text {Remington, pp. } 167-168 .}
\end{aligned}
$$

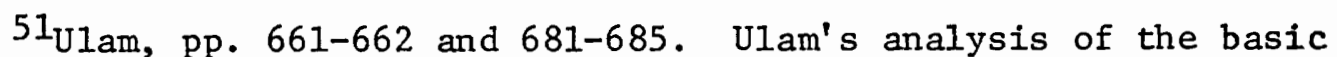
causes of the Sino-Soviet conflict are quite relevant in the light of Djilas' assertions regarding the role which the commitment to industrialization plays in Communist politics and human history generally. Regarding the causes of the dispute, Ulam writes, ". . the basic one is that Russia is now highly industrialized, while China is not but has 600 million people. The Chinese view Russia's intermittent attempts to reach accommodation with the United States as expressing not only personal cowardice and treason on Khrushchev's part, but also an un-Marxist and un-Leninist revision on the part of the Soviet elite." Ulam continues with regard to the dating of the origins of the SinoSoviet dispute, "From this point of view, the root of the trouble goes to the original denunciation of Stalin, which the Chinese believe --quite logically, from their point of view--lowered the prestige of Communism in the international arena and opened the door to the evolution of Soviet society and policies on the pattern of Yugoslavia." (Ulam, p. 682.) 


\section{A SELECTED BIBLIOGRAPHY}

Alexandrov, A. et al. History of Soviet Foreign Policy 1945-1970. B. Ponomaryov, A. Gromyko, V. Khvostov, eds. Moscow: Progress Publishers, 1973.

Aspaturian, Vernon V. "A Half Century of Soviet Foreign Policy," in Vernon V. Aspaturian, ed., Process and Power in Soviet Foreign Policy. Boston: Little, Brown and Company, 1971, pp. 87-111. - "Introduction," in Vemon V. Aspaturian, ed., Process and Power in Soviet Foreign Policy. Boston: Little, Brown and Company, 1971, p. 3-83.

Auty, Phyllis. Tito, A Biography. London: Longman Group Limited, 1970.

"A Biographical Note On Milovan Djilas," in Milovan Djilas, The Unperfect Society, Beyond the New Class. New York: Harcourt, Brace and Wor1d, 1969, pp. vii-xi.

Brzezinski, Zbigniew K. The Soviet Bloc: Unity and Conflict. Rev. ed. New York: Praeger, 1961.

Caldwe11, Lawrence T. "The Warsaw Pact: Directions of Change," Problems of Communism 24 (October 1975): 1-19.

Campbe11, Robert $W$. The Soviet-type Economies: Performance and Evolution. 3rd ed. Boston: Houghton Mifflin, 1974.

Central Committee of the Communist Party of the Soviet Union, "On the Anti-Party Group of G. M. Malenkov, I. M. Kaganovich, and V. M. Molotov, June 29, 1957," in The Current Digest of the Soviet Press 9 (July 1957): 264-267, in Robert V. Daniels, ed., A Documentary History of Communism. 2 vols. New York: Random House, 1960, vol. 2, pp. 264-267.

Clemens, Diane Shaver. Yalta. New York: Oxford University Press, 1970.

Ciechanowski, Jan. Defeat in Victory. Garden City, N. Y.: Doubleday and Company, 1947.

"The COMECON Charter," Treaties and Alliances of the World, An International Survey Covering Treaties in Force and Communities of States. New York: Charles Scribner's Sons, 1974, pp. 129-132. 
Czerwinski, E. J., and Jaroslaw Piekalkiewicz, eds. The Soviet Invasion of Czechoslovakia: Its Effects on Eastern Europe. New York: Praeger, 1972 .

Dallin, David J. Soviet Foreign Policy After Stalin. New York: J. B. Lippincott Company, 1961.

"Declaration of the Conference of Representatives of Communist and Workers'. Parties of Socialist Countries, Mos cow, November, 1957," in The Current Digest of the Soviet Press 9 (January 1958): 4-7, in Robert V. Daniels, ed., A Documentary History of Communism. 2 vols. New York: Random House, 1970, vol. 2, pp. 270-273.

"Declaration by the Government of the USSR on the Principles of Development and Further Strengthening of Friendship and Cooperation Between the Soviet Union and Other Socialist States, October 30, 1956," in Pravda, October 31, 1956, in Paul E. Zinner, ed., National Communism and Popular Revolt in Eastern Europe. New York: Columbia University Press, 1956, pp. 485-489.

Delzell, Charles F. "Russian Power in Central-Eastern Europe," in John L. Sne11, ed., The Meaning of Yalta. Baton Rouge: Louisiana State University Press, 1956, pp. 75-126.

Djilas, Milovan. The New Class: An Analysis of the Communist System. New York: Praeger, 1957.

- Conversations With Stalin. Translated by Michael B. Petrovich. New York: Harcourt, Brace and World, 1962.

- The Unperfect Society: Beyond the New Class. Translated by Dorian Cooke. New York: Harcourt, Brace and World, 1968.

Dmytryshyn, Basil. USSR: A Concise History. 2nd ed. New York: Charles Scribner's Sons, 1971.

Dziewanowski, M. K. The Communist Party of Poland. Cambridge: Harvard University Press, 1959.

Feis, Herbert. Between War and Peace, The Potsdam Conference. Princeton: Princet on University Press, 1960.

Great Britain. Foreign Office. British Foreign and State Papers, "Agreement Between Poland and The Soviet Union, 30 July 1941," vol. 14.4, in J. A. S. Grenville. The Major International Treaties 1914-1973. New York: Stein and Day, 1974, Pp. 214-215.

- British Foreign and State Papers, "Treaty of Friendship and Mutual Assistance and Post-War Cooperation Between The Soviet Union and Czechoslovakia, 12 December 1943," vol. 143, in J. A. S. Grenville, The Major International Treaties 1914-1973. New York: Stein and Day, 1974, pp. 215-216. 
Halasz, Nicholas. In the Shadow of Russia: Eastern Europe in the Postwar World. New York: Ronald Press, 1959.

Halle, Louis J. "The Cold War As History," from Louis J. Halle, The Cold War As History. New York: Harper and Row, 1971, in Gordon Wright and Arthur Mejia, eds., An Age of Controversy. Alt. ed. New York: Dodd, Mead and Company, 1972, pp. 262-270.

Hoffman, George W., and Fred Warner Neal. Yugoslavia and the New Communism. New York: Twentieth Century Fund, 1962.

Holling, C. S. "Resilience and Stability of Ecological Systems," Annual Review of Ecology and Systematics 4 (1973).

Kaser, Michae1. Comecon: Integration Problems of the Planned Economies. London: Oxford University Press, 1965.

Khrushchev, Nikita S. Khrushchev Remembers. Edited and translated by Strobe Talbott. Annotated by Edward Crankshaw. New York: Bantam Books, 1971.

Lesechko, M. "Stages of COMECON Economic Integration," Kommunist No. 16 (1975), in Reprints From the Soviet Press 22 (January 1976): 45-55

Latiche, J. M. "Soviet Foreign Economic Policy: Trade and Assistance Programs," in Jaan Pennar, ed., Report on the Soviet Union in 1956. Munich: Institute for the Study of the USSR, 1956, pp. 172-191.

Mackintosh, J. M. Strategy and Tactics of Soviet Foreign Policy. New York: Oxford University Press, 1963.

Mellor, R. E. H. Comecon: Challenge to the West. New York: Van Nostrand Reinhold, 1971.

"Official Charges Against L. P. Beria and His Associates, December, 1953," Isvestia, December 17, 1953, trans. Basil Dmytryshyn in Basil Dmytryshyn, USSR: A Concise History. New York: Charles Scribner's Sons, 1971, pp. 475-480.

Remington, Robin Alison. The Warsaw Pact: Case Studies in Communist Conflict Resolution. Cambridge: M. I. T. Press, 1971.

Rozek, Edward J. Allied Wartime Diplomacy, A Pattern in Poland. New York: John Wiley and Sons, 1958.

Schwartz, Harry. The Soviet Economy Since Stalin. New York: J. B. Lippincott Company, 1965.

Schwartz, Morton. The Foreign Policy of the USSR: Domestic Factors. Encino: Dickens on Publishing Company, 1975. 
Selucky, Radaslav. Economic Reforms in Eastern Europe: Political Background and Economic Significance. Translated by Elias Zdenek. New York: Praeger, 1972.

Seton-Watson, Hugh. The New Imperialism. Totawa: Rowman and Littlefield, 1971.

Shub, Anatole. An Empire Loses Hope: The Return of Stalin's Ghost. New York: W. W. Norton and Company, 1970.

Slepov, L. "Collectivity is the Highest Principle of Party Leadership," in Pravda, April 16, 1953, in The Current Digest of the Soviet Press 5 (March 1953): 3, 30, in Robert V. Daniels, ed., A Documentary History of Communism. 2 vols. New. York: Random House, 1960, vol. 2, pp. 207-210.

Spulber, Nicolas. The Economics of Communist Eastern Europe. New York: The Technology Press of the Massachusetts Institute of Technology and John Wiley and Sons, 1957:

Stalin, Joseph V. "Economic Problems of Socialism in the U.S.S.R.," in The Essential Stalin. Edited by Bruce Franklin. Garden City: Doubleday and Company, 1972, pp. 445-481.

- "Stalin's 'Election' Speech, February 9, 1946," Bolshevik, No. 3, (March 1946): 1-11, trans. Basil Dmytryshyn in Basil Dmytryshyn, USSR: A Concise History. New York: Charles Scribner's Sons, 1971 , pp. 450-459.

- "Stalin's Last Speech, October 17, 1952," For A Lasting Peace, For A People's Democracy, No. 42 (206), October 17, 1952, p. 1, in Basil Dmytryshyn, USSR: A Concise History. New York: Charles Scribner's Sons, 1971, pp. 472-474.

"Text of the Constitution of the Union of Socialist Soviet Republics," in James H. Meise1 and Edward S. Kozera, eds., Materials for the Study of the Soviet System. 2nd, rev. ed. Ann Arbor: George Wahr Publishing, 1953, pp. 153-168.

Trend, Harry. "Comecon's Organizational Structure," Radio Free Europe RAD Background Report/138 (Eastern Europe), October 7, 1975.

Ularn, Adam B. Expansion and Coexistence. 2nd ed. New York: Praeger, 1974.

United Nations. Treaty Series. Treaties and International Agreements Registered or Filed and Reported with the Secretariat of the United Nations, vol. 12, "Agreement Regarding Friendship, Mutual Assistance and Post-War Cooperation Between the Soviet Union and the Polish Republic, Moscow, 21 April 1945," in J. A. S. Grenville, The Major International Treatjes 1914-1973. New York: Stein and Day, 1974, pp. 361-362. 
United Nations. Treaty Series. Treaties and International Agreements Registered or Filed and Reported with the Secretariat of the United Nations, vol. 48, "Treaty of Friendship, Collaboration and Mutual Assistance Between the Rumanian People's Republic and the Soviet Union, Moscow, 4 February 1948," in J. A. S. Grenville, The Major International Treaties 1914-1973. New York: Stein and Day, 1974, P. 364.

- Treaty Series. Treaties and International Agreements Registered or Filed and Reported with the Secretariat of the United Nations, vol. 219, "Tre aty of Friendship, Cooperation and Mutual Assistance Between Albania, Bulgaria, Hungary, The German Democratic Republic, Poland, Rumania, The Soviet Union, and Czechoslovakia [Warsaw Pact] Warsaw, 14 May 1955," in J. A. S. Grenville, The Major International Treaties 1914-1973. New York: Stein and Day, 1974, pp. 365-367.

United States Department of State. American Foreign Policy 1950-1955. "The Wars aw Security Pact, May 14, 1955." Washington, D. C.: Government Printing Office, 19.57, vol. 1, pp. 1239-1242, in Basil Dmytryshyn. USSR: A Concise History. New York: Charles Scribner's Sons, 1971, pp. 481-484.

Wesson, Robert G. The Russian Dilemma: A Political and Geopolitical View. New Brunswick: Rutgers University Press, 1974.

Wilczynski, J. The Economics of Socialism. Chicago: Aldine Publishing Company, 1970 .

Willis, F. Roy. Europe in the Global Age: 1939 to the Present. New York: Dodd, Mead and Company, 1968.

Wolfe, Thomas W. Soviet Power and Europe, 1945-1970. Baltimore: The Johns Hopkins Press, 1970.

Yowev, Stefan. "National Communism," Bulletin of the Institute for the Study of the USSR 4 (May 1957): 3-18.

Zartman, I. William, ed. Czechoslovakia, Intervention and Impact. New York: New York University Press, 1970. 


\section{APPENDIX A}

AGREEMENT BETWEEN POLAND AND THE SOVIET UNION, 30 JULY 19411

"The Government of the Republic of Poland and the Government of the Union of Soviet Socialist Republics have concluded the present Agreement and decided as follows:

"1. The Government of the Union of Soviet Socialist Republics recognizes that the Soviet-German treaties of 1939 relative to territorial changes in Poland have lost their validity. The Government of the Republic of Poland declares that Poland is not bound by any Agreement with any third State directed against the U.S.S.R."

"2. Diplomatic relations will be restored between the two Governments upon the signature of this Agreement and an exchange of Ambassadors will follow immediately."

"3. The two Governments mutually undertake to render one another aid and support of all kinds in the present war against Hitlerite Germany."

"4. The Government of the Union of Soviet Socialist Republics expresses its consent to the formation on the territory of the Union of Soviet Socialist Republics of a Polish army under a commander appointed by the Government of the Republic of Poland, in agreement with the

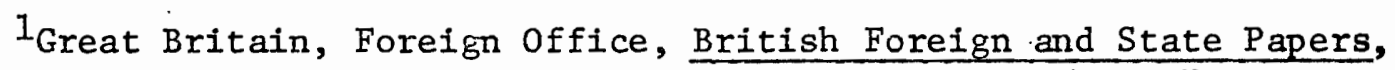
"Agreement Between Poland and The Soviet Union, 30 July 1941," vo1. 144, pp. $869 \mathrm{ff}$., in J. A. S. Grenville, The Major International Treaties 1914-1973 (New York: Stein and Day, 1974), pp. 214-215. 
Government of the Union of Soviet Socialist Republics. The Polish army on the territory of the Union of Soviet Socialist Republics will be subordinated in operational matters to the Supreme Command of the U.S.S.R. on which there will be a representative of the Polish army. All details as to command, organization and employment of this force will be settled in a subsequent agreement."

"5. This Agreement will come into force immediately upon its signature and without ratification. The present Agreement is drawn up in two copies, each of them in the Russian and Polish languages. Both texts have equal force."

"Secret. Protocol"

"1. Various claims both of public and private nature will be dealt with in the course of further negotiations between the two Governments. ${ }^{.3}$

"2. This Protocol enters into force simultaneously with the Agreement of the 30th of July, 1941."

"Protoco1"

"1. As soon as diplomatic relations are re-established the Government of the Union of Soviet Socialist Republics will grant amnesty to all Polish citizens who are at present deprived of their freedom on the territory of the U.S.S.R. either as prisoners of war or on other adequate grounds."

"2. The present Protocol comes into force simultaneously with the Agreement of July 30, 1941." 


\title{
APPENDIX B
}

\begin{abstract}
AGREEMENT REGARDING FRIENDSHIP, MUTUAL ASSISTANCE AND
POST-WAR COOPERATION BETWEEN THE SOVIET UNION AND

THE POLISH REPUBLIC, MOSCOW, 21 APRIL 19451
\end{abstract}

"The President of the National Council of the Homeland and the Presidium of the Supreme Council of the Union of Socialist Soviet Republics moved by an unshaken determination to bring, in a common effort, the war with the German aggressors to a complete and final victory;

"Wishing to consolidate the fundamental change in the history of the Polish-Soviet relations in the direction of friendly cooperation, which has taken place in course of a common fight against the German imperialism;

"Trusting that a further consolidation of good neighbourly relations and friendship between Poland and her direct neighbour - the U.S.S.R. - is vital to the interests of the Polish and Soviet peoples;

"Confident that friendship and close cooperation between the Polish people and the Soviet people will serve the cause of successful economic development of both countries during the war as well as after the war;

"Wishing to support after the war by all possible means the cause of peace and security of peoples;

$1_{\text {United Nations, Treaty Series. Treaties and International }}$ Agreements Registered or Filed and Reported with the Secretariat of the United Nations, vol. 12, "Agreement Regarding Friendship, Mutual Assistance and Post-War Cooperation Between the Soviet Union and The Polish Republic, Moscow, 21 April 1945," pp. 391ff., in Grenville, pp. 361-362. 
"Have resolved to conclude this agreement and have... appointed as their plenipotentiaries:

"The President of the National Council of the Homeland - Edward Osobka-Morawski, the President of the Council of Ministers and the Minister of Foreign Affairs of the Polish Republic,"

"The Presidium of the Supreme Council of the Union of Socialist Soviet Republics - Joseph Vissarionovitch Stalin, Chairman of the Council of People's Commissars of the U.S.S.R.;

"Who, after exchange of full powers which were recognized as being in order and drawn up in due form, have agreed as follows:

"Article 1. The High Contracting Parties jointly with all United Nations will continue the fight against Germany until final victory. In that fight the High Contracting Parties undertake to give one another mutual military and other assistance using all the means at their disposal."

"Article 2. The High Contracting Parties, in a firm belief that in the interest of security and successful development of the Polish and Soviet peoples it is necessary to preserve and to strengthen lasting and unshaken friendship during the war as well as after the war, will strengthen the friendly cooperation between the two countries in accordance with the principles of mutual respect for their independence and sovereignty and non-interference in the internal affairs of the other Government."

"Article 3. The High Contracting Parties further undertake that even after the end of the present war they will jointly use all the means at their disposal in order to eliminate every possible menace of a new aggression on the part of Germany or on the part of any other Govern- 
ment whatsoever which would be directly or in any other manner allied with Germany."

"For this purpose the High Contracting Parties will, in a spirit of most sincere collaboration, take part in all international activities aiming at ensuring peace and security of peoples and will contribute their full share to the cause of realization of these high ideals." "The High Contracting Parties will execute this Agreement in compliance with the international principles in the establishment of which both Contracting Parties took part."

"Article 4. If one of the High Contracting Parties during the post-war period should become involved in war operations against Germany in case she should resume aggressive policy or against any other Government whatsoever which would be allied with Germany directly or in any other form in such a war the other High Contracting Party will immediately extend to the other Contracting Party which is involved in military operations military and other support with all the means at its disposal."

"Article 5. The High Contracting Parties undertake not to sign without. mutual consent an armistice or a peace treaty with the Hitlerite Government or any other authority in Germany which menaces or may menace the independence, territorial integrity or security of either of the two High Contracting Parties."

"Article 6. Each of the High Contracting Parties undertakes not to enter into any alliance or to take part in any coalition directed against the other High Contracting Party." 
"Article 7. The High Contracting Parties will cooperate in a spirit of friendship also after the end of the present war for the purpose of developing and strengthening the economic and cultural relations between the two countries and will give mutual assistance in the economic reconstruction of the two countries."

"Article 8. This Agreement comes into force from the moment of signing and is liable to ratification within the shortest possible period. Exchange of ratifying documents will take place in Warsaw as soon as possible."

"This Agreement will remain in force for twenty years after the moment of signing."

"If one of the High Contracting Parties does not make a statement twelve months before the expiration of the twenty years period to the effect that it wishes to give notice, this Agreement will remain in force for a further period of five years and so on until one of the High Contracting Parties makes a statement in writing twelve months before the expiration of a successive five years period to the effect that it intends to give notice of the Agreement."

"In witness whereof the mandatories have signed this Agreement and have apposed their seals thereto."

"Drawn up in Moscow on April 21, 1945, in duplicate, each copy in Polish and in Russian, both texts being equally binding." 
"By authority of the President of the National Council of the Homeland."

\section{Osobka-Morawski}

"By authority of the Presidium of the Supreme Council of the U.S.S.R."

\section{J. Stalin}

"After consideration this Agreement has been recognized equitable in its whole as well as in individual provisions contained therein; it is, therefore, announced that it has been accepted, ratified and approved and will be strictly complied with."

"In witness whereof this Act has been issued with the seal of the Polish Republic duly apposed thereto."

WARSAW, September 19, 1945

President of the National Council of the Homeland Boleslaw Bierut

President of the Council of Ministers

Edward Osobka-Morawski

Vice-Minister of Foreign Affairs

P. P. Z. Modzelewski" 
APPENDIX C

TREATY OF FRIENDSHIP AND MUTUAL ASSISTANCE AND POST-WAR COOPERATION BETWEEN THE SOVIET UNION AND CZECHOSLOVAKIA, MOSCOW, 12 DECEMBER $1943^{1}$

"The Presidium of the Supreme Soviet of the Union of Soviet Socialist Republics and the President of the Czechoslovakian Republic, desiring to modify and supplement the Treaty of Mutual Assistance existing between the Union of Soviet Socialist Republics and the Czechoslovakian Republic and signed in Prague on May 16, 1935, and to confirm the terms of the Agreement between the Government of the Union of Soviet Socialist Republics and the Government of the Czechoslovakian Republic concerning joint action in the war against Germany, signed July 18, 1941, in London; desiring to cooperate after the war to maintain peace and to prevent further aggression on the part of Germany and to assure permanent friendship and peaceful post-war cooperation between them, have resolved to conclude for this purpose a Treaty and .. . have agreed to the following:

"Article 1. The High Contracting Parties, having agreed mutually to join in a policy of permanent friendship and friendly post-war cooperation, as well as of mutual assistance, engage to extend to each other military and other assistance and support of all kinds in the present war against Germany and against all those States which are associated with it in acts of aggression in Europe."

$1_{\text {Great Britain, Foreign Office, British Foreign and State Papers, }}$ "Treaty of Friendship and Mutual Assistance and Post-War Cooperation Between the Soviet Union and Czechoslovakia, 12 December 1943," vo1. 143, pp. 238ff., in Grenville, pp. 215-216. 
"Article 2. The High Contracting Parties engage not to enter during the period of the present war into any negotiations with the Hitler Government or with any other Government in Germany which does not clearly renounce all aggressive intentions, and not to carry on negotiations and not to conclude without mutual agreement any armistice or other treaty of peace with Germany or with any other State associated with it in acts of aggression in Europe."

"Article 3. Affirming their pre-war policy of peace and mutual assistance, expressed in the treaty signed at Prague on May 16, 1935, the High Contracting Parties, in çase one of them in the period after the war should become involved in military action with Germany, which might resume its policy of 'Drang nach Osten,' or with any other State which might join with Germany directly or in any other form in such a war, engage to extend immediately to the other Contracting Party thus involved in military action all manner of military and other support and assistance at its disposal."

"Article 4. The High Contracting Parties, having regard to the security interests of each of them, agree to close and friendly cooperation in the period after the restoration of peace and agree to act in accordance with the principles of mutual, respect for their independence and sovereignty, as well as of non-interference in the internal affairs of the other State. They agree to develop their economic relations to the fullest possible extent and to extend to each other all possible economic assistance after the war."

"Article 5. Each of the High Contracting Parties engages not to conclude any alliance and not to take part in any coalition directed against the other High Contracting Party." 
"Article 6. The present Treaty shall come into force immediately after signature and shall be ratified within the shortest possible time; the exchange of ratifications will take place in Moscow as soon as possible."

"The present Treaty shall remain in force for a period of twenty years from the date of signature, and if one of the High Contracting Parties at the end of this period of twenty years does not give notice of its desire to terminate the Treaty twelve months before its expiration, it will continue to remain in force for the following five years and for each ensuing five-year period unless one of the High Contracting Parties gives notice in writing twelve months before the expiration of the current five-year period of its intention to terminate it."

"Protocol"

"On the conclusion of the Treaty of Friendship, Mutual Assistance and Post-War Cooperation between the Union of Soviet Socialist Republics and the Czechoslovakian Republic the High Contracting Parties undertake that, in the event that any third country bordering on the U.S.S.R. or the Czechoslovakian Republic and constituting in this war an object of German aggression desires to subscribe to this Treaty, it will be given the opportunity, upon the joint agreement of the Governments of the U.S.S.R. and the Czechoslovakian RepubIic, to adhere to this Treaty, which will thus acquire the character of a tripartite agreement." 
"By authority of the Presidium of the Supreme Council of the U.S.S.R.

V. Molotov

"By authority of the President of the Czechoslovakian Republic

Z. Fierlinger" 
APPENDIX D

INDICES OF MAJOR CROP PRODUCTION

IN THE BLOC, 1948-19551

(1934-1938 = 100; "b": All grains totaled under bread grains)

\begin{tabular}{|c|c|c|c|c|c|c|}
\hline & & BREAD & AIN & & ARSE G & \\
\hline & 1948 & 1953 & .1955 & 1948 & 1953 & $1955^{\circ}$ \\
\hline Czechoslovakia & 81.8 & 83.0 & 81.1 & 97.8 & 107.9 & 112.0 \\
\hline Poland & 89.8 & 76.0 & 108.8 & 75.3 & 79.0 & 82.9 \\
\hline Hungary & 80.8 & 94.1 & 92.4 & 97.1 & 105.3 & 115.9 \\
\hline Rumania & 90.4 & $75.7 \mathrm{~b}$ & $151.4 \mathrm{~b}$ & 104 & $-b$ & $-b$ \\
\hline Bulgaria & 99.0 & 132.3 & 112.0 & 81.5 & 105.9 & 151.9 \\
\hline Yugoslavia & 104.2 & 105.6 & 101.1 & 87.7 & 85.4 & 84.1 \\
\hline & & POTATO & & & JGAR-B & \\
\hline & 1948 & 1953 & 1955 & 1948 & 1953 & 1955 \\
\hline Czechoslovakia & 55.2 & 71.7 & ? & 74.5 & 94.7 & ? \\
\hline Poland & 70.3 & 114.5 & 98.6 & 70.8 & 162.8 & 172.0 \\
\hline Hungary & 103.2 & 93.8 & 98.6 & 123.0 & 265.0 & 220.0 \\
\hline Rumania & 87.8 & 185.3 & ? & 203.5 & 326.6 & 502.5 \\
\hline Bulgaria & 89.2 & ? & ? & 178.1 & 344.1 & 349.3 \\
\hline Yugoslavia & 100.0 & 140.9 & 153.9 & 294.8 & 298.0 & 271.7 \\
\hline
\end{tabular}




\section{APPENDIX E}

PERCENT OF AGRICULTURAL LAND IN THE SOCIALIST SECTORI

("-": unavailable)

$\begin{array}{lrrrrrr} & 1952 & 1953 & 1954 & 1956 & 1957 & 1958 \\ \text { Poland } & 13 & 17 & 19 & 24 & 14 & 15 \\ \text { Czechoslovakia } & 24 & 48 & 44 & 45 & 70 & 77 \\ \text { Rumania } & 19 & 21 & 26 & 35 & 50 & 51 \\ \text { Hungary } & 25 & 37 & 32 & 33 & 22 & 23 \\ \text { Bulgarla } & 50 & 62 & 60 & 62 & 90 & 92 \\ \text { East Germany } & 5 & 8 & 30 & 33 & 40 & - \\ \text { Yugoslavia } & - & 24 & - & 9 & - & -\end{array}$

$1_{\text {Brzezinski, p. } 99 .}$ 


\section{APPENDIX F}

BLOC STATES'FOREIGN TRADE WITH THE USSR AND OTHER BLOC STATES AS A PERCENTAGE OF TOTAL FOREIGN TRADE1

\begin{tabular}{|c|c|c|c|c|c|}
\hline & 1937 & 1948 & 1949 & 1950 & 1951 \\
\hline Bulgaria & 12 & 74 & 82 & 88 & 92 \\
\hline Hungary & 13 & $\begin{array}{r}34 \\
\vdots\end{array}$ & 46 & 61 & 67 \\
\hline Poland & 7 & 34 & 43 & 59 & 58 \\
\hline Rumania & 18 & 71 & 82 & 83 & 79 \\
\hline Czechoslovakia & 11 & 30 & 45 & 52 & 60 \\
\hline
\end{tabular}

${ }^{1}$ Ibid., p. 127. 
APPENDIX G

NETWORK OF LONG-TERM TRADE AGREEMENTS CONCLUDED BETWEEN COMECON MEMBERS IN 1950-19511

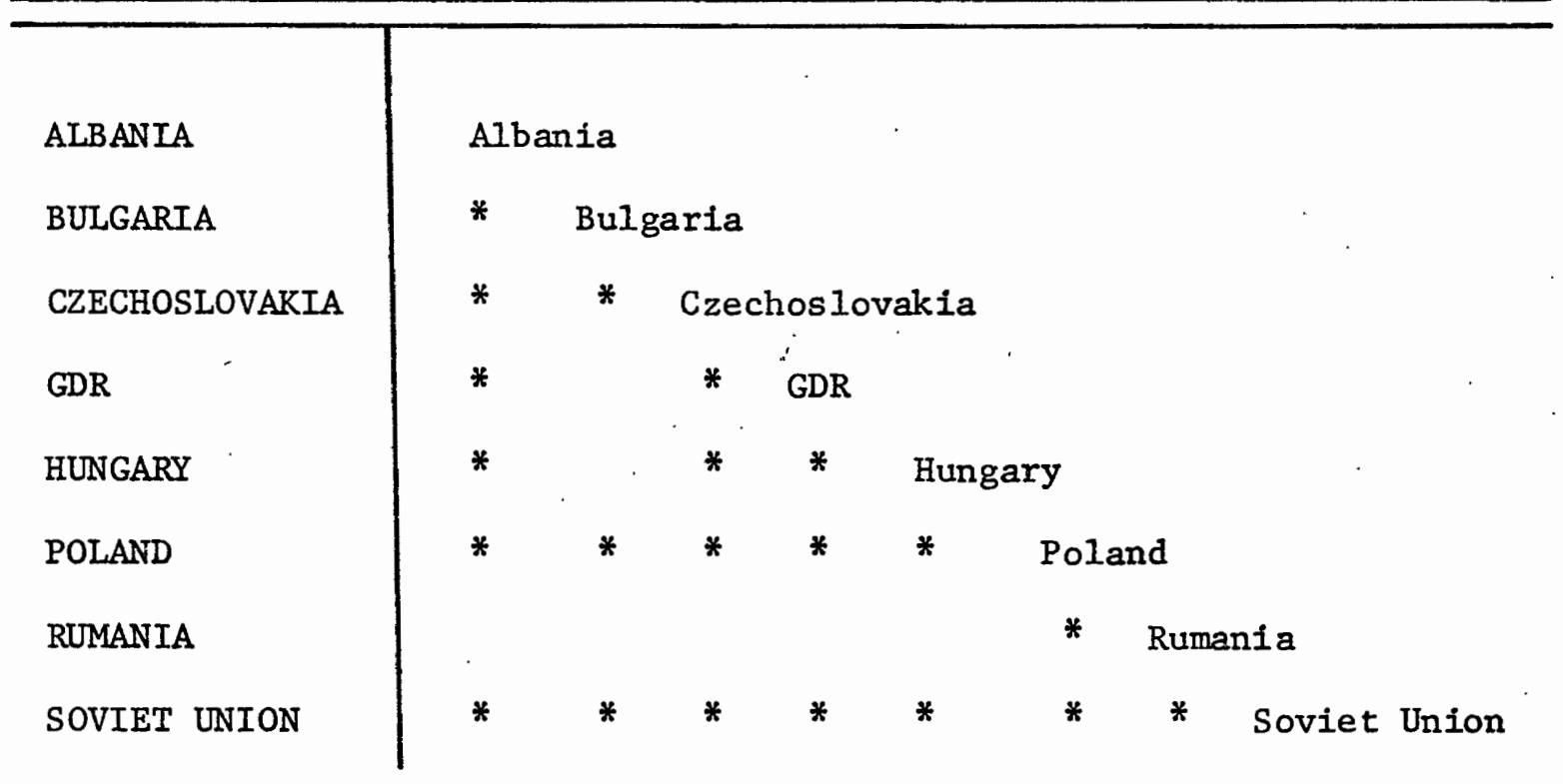




\section{APPENDIX H}

\section{COMECON'S FOUNDING COMMUNIOUE: \\ JANUARY $22,1949^{1}$}

"In January of this year an economic conference was held in Moscow attended by delegates from Bulgaria, Hungary, Poland, Rumania, the USSR, and Czechoslovakia. The conference noted considerable successes in the development of the economic relations among the countries concerned and above all the great rise in the turnover of trade. As a result of the above-mentioned economic relations and the implementation of economic co-operation between the countries of people's democracy and the USSR, conditions have been created to accelerate the restoration and development of their national economies. The conference further observed that the Governments of the United States of America, of Great Britain, and of certain western European states had boycotted trade relations with the countries of people's democracy and the USSR because these countries did not consider it appropriate that they should submit themselves to the dictatorship of the Marshall Plan, which would have violated their sovereignty and the interests of their national economies. In the light of these circumstances, the meeting studied the question of the possibility of organizing wider economic co-operation between the countries of people's democracy and the USSR. To establish this wider economic co--operation between the countries of people's democracy and the USSR,

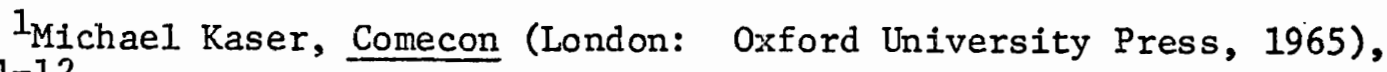
pp. 11-12. 
the conference considered it necessary to create the Council for Mutual Economic Assistance between the countries represented--on the basis of equal representation and with the task of exchanging economic experience, extending technical aid to one another and rendering mutual assistance with respect to raw materials, foodstuffs, machines, equipment, etc. The meeting decided that the Council for Mutual Economic Assistance would be an organization open to other countries of Europe sharing the principles of the Council for Mutual Assistance and desirous of participating in the widening of economic co-operation with the above-mentioned countries. The Council for Mutual Economic Assistance would take a decision only with the agreement of the interested country. The Council shall meet periodically in the capital of each of the signatory countries in turn under the chairmanship of the representative of the country in whose capital the session takes place." 
APPENDIX H (continued)

THE COMECON CHARTER 1

"At its 12th session in December 1959, the Council drafted a Charter, which was signed on Dec. 14, 1959, and came into force on April 13, 1960."

"A sumary of the Charter is given below:

In the preamble the signatories state their determination 'to continue developing all-round economic co-operation on the basis of the consistent implementation of the international socialist division of labor in the interests of building Socialism and Communism in their countries and ensuring a lasting peace throughout the world.' They also state their 'readiness to develop economic relations with. all countries, irrespective of their social and State systems.'

Art. 1. The purpose of the CMEA is to facilitate, by uniting and co-ordinating the efforts of the Council's mentiber countries, the planned development of the national economy, acceleration of economic and technical progress in these countries, a rise in the level of industrialization in countries with less developed industries, uninterrupted growth of labor productivity, and a steady advance of the welfare of the peoples in the Council's member-countries.

Art. 2 deals with membership of the CMEA. Membership is open to any European country sharing the Council's aims and principles. Any member-country may leave the Council with six months' notice. This article was amended at the 16th session of the Council, when admission to membership was extended to non-European countries.

Art. 3 states the functions of the CMEA to be to:

(a) 'organize all-round economic, scientific and technical co-operation of all the Council's member-countries in the

l"The COMECON Charter," Treaties and Alliances of the World, An International Survey Covering Treaties in Force and Communities of States (New York: Charles Scribner's Sons, 1974), pp. 129-132. 
most rational use of their natural resources and acceleration of the development of their productive forces'; and

(b) 'assist the Council's member-countries in elaborating and carrying out joint measures for:

(i) the development of the industry and agriculture of the Council's member-countries; (ii) the development of transport . . . ; (iii) the most efficient use of principal capital investments allocated by the Council's membercountries for the development of the mining and manufacturing industries and for the construction of major projects which are of interest to two countries or more; (iv) the development of trade and exchange of services between the Council's member-countries and between them and other countries; (v) the exchange of scientific and technical achievements and advanced production experience.'

Art. 4 states that 'recommendations shall be made on questions of economic, scientific, and technical co-operation' and on 'decisions on organizational and procedural matters.' Recommendations and decisions apply only to those members who have declared an interest in the question from which they arise.

Art. 5 names the constituent organs of the Council as the Session of the Council; the Conference of Members' Representatives (since replaced by the Executive Committee); the Standing Commissions; and the Secretariat.

Arts. $6,7,8$ and 9 give details of the composition and functions of the organs of the Council.

The remaining articles deal with the Council's international relations and financial arrangements, and with such matters as the ratification and amending of the Charter.

\section{"ORGANIZATION OF THE COUNCIL"}

\section{"Summit Conferences"}

"Since June 1962 the first secretaries of the Central Committees of the Communist and Workers' Parties and the Heads of Government of the member-countries of Comecon have met in conference from time to time to discuss the expansion and consolidation of economic co-operation among Comecon countries. At these summit conferences the general lines of Comecon's work are laid down." 
"Session of the Council"

"The supreme permanent organ of Comecon is the Session of the Council, which meets at least once a year in the capital of each membercountry in turn, the host-country providing the chairman for each Session. The program of work discussed at the summit conferences is here determined in greater detail. Recommendations, which must be passed unanimously, are put into effect by inter-governmental agreements."

"Executive Committee"

"The Executive Committee was set up at the 16th Session of the Council on July 7, 1962. It consists of Deputy Prime Ministers of the Comecon member-countries, their deputies, and advisers. Meetings are held at least every two months, the function of the Committee being to co-ordinate national economic development plans and to supervise collaboration in scientific and technical research. A branch of the Executive Committee is the Bureau for Common Questions of Economic Planning, in which each Comecon country is represented by the Deputy Chairman of the State Planning Organization."

"Secretariat"

The Secretariat consists, at present, of the Secretary of the Council and six Deputy Secretaries. It is responsible for preparation of material for the Council, the Committee, and the Permanent Commissions, and for the drafting of reports and the compiling of statistics."

"Permanent Commissions"

"Twenty-three Permanent Commissions were set up at various times to study different aspects of Comecon's work. All the Comecon member- 
countries are represented on each of the committees and sub-committees of the Permanent Commissions."

"The Commissions are listed below, together with their date of foundation and present headquarters.

Agriculture
Forestry
Power
Coal Industry
Machine Building
Oil and Gas
Ferrous Metals
Non-ferrous Metals
Chemical Industry
Wood, Cellulose, Paper
Transport
Construction
Light Industry
Food Industry
Economic Questions
Foreign Trade
Peaceful Uses of Atomic Energy
Standardization
Co-ordination of Scientific.
$\quad$ and Technical Research
Statistics
Finance and Currency
Radio and Electronics Industries
Geology

(May 1956; Sof1a)

(May 1956; Bucharest)

(May 1956; Moscow)

(May 1956; Warsaw)

(May 1956; Prague)

(May 1956; Bucharest)

(May 1956; Moscow)

(May 1956; Budapest)

(May 1956; Berlin)

(May 1956; Budapest)

(June 1958; Warsaw)

(June 1958; Berlin)

Created as a

(July 1963; Prague)) single commis(July 1963; Sofia) ) sion in December, (1958; Moscow) 1958.

(May 1959; Moscow)

(Sept. 1960; Moscow)

(June 1962; Berlin)

(June 1962; Moscow)

(June 1962; Moscow)

(Dec. 1962; Moscow)

(July 1963; Budapest)

(July 1963; Ulan-Bator)"

"The creation of a Permanent Commission for Posts and Telecomunications was decided upon by the Council at its 25 th Session held in Bucharest, July 27-29, 1971."

"The Permanent Commission for the Co-ordination of Scientific and Technical Research was at the same time replaced by a Comittee for Scientific and Technical Co-operation, and a Committee for Co-operation in the Sphere of Planning was also set up." 


\section{"INTERNATIONAL INVESTMENT BANK"}

"An International Investment Bank, with its seat in Moscow, was set up on July 10, 1970, by 7 countries as founder-members (Bulgaria, Czechoslovakia, the German Democratic Republic, Hungary, Mongolia, Poland, and the Soviet Union). Romania became a member of the bank on Jan. 12, 1971."

"Starting operations on Jan. 1, 1971, with initial capital subscriptions totaling $175,000,000$ rubles (to be increased by another 175,000,000 rubles in 1972 and a total of 650,000,000 in later years), the bank was to concentrate resources for capital construction and for co-ordinated expenditure through the granting of long- and medium-term credits. Membership subscriptions were based on the volume of members' exports in mutual trade turnover, with the Soviet Union providing nearly 40 percent and Eastern Germany about 17.6 percent of the capital. The bank was also authorized to use loans and investments from third countries."

\footnotetext{
"INTERNATIONAL BANK FOR ECONOMIC CO-OPERATION"
}

"An International Bank for Economic Co-operation, formed by Comecon's eight member-countries with an initial capital of $60,000,000$ rubles (to be increased to $300,000,000$ rubles within five years), came into being on Jan. 1, 1964."

\section{"OTHER INSTITUTIONS"}

"Other permanent bodies created by the Council are a Working Party 
for the Co-ordination and Delivery of Finished Articles (founded probably in 1959) and a Central Dispatcher Administration (founded in 1962)."

"A Standardization Institute was established in 1964, its function being the creation of a progressive standardization of industrial products among the Comecon member-countries."

"The creation of an International Institute of Economic Problems of the World Socialist System was approved by Comecon's Executive Committee on July 24, 1970."

\section{"Division of Labor"}

"The work of Comecon is largely based on the principle of the division of labor. In Sessions of the Council from 1956 to 1961 a number of plans were approved for specialization, in various industries, among the Comecon countries. At the Session of the Council from Dec. 12-15, 1961, the draft of the 'Fundamental Principles of International Socialist Division of Labor' was adopted. The details of the document were published on June 17, 1962. Described as 'a planned and consciously molded process, which takes into consideration the objectively operating economic laws of Socialism,' the Principles are contrasted with the competitive system of capitalist international division. All later resolutions of Comecon in the field of the division of labor are based on this document."

\section{"COMPLEX PROGRAM"}

"The Council published on Aug. 7, 1971, a 'Complex Program for the Further Deepening and Improvement of Co-operation and Development of the Socialist Economic Integration of the CMEA Member-Countries." 
The purpose of the program was stated to be 'the promotion of the growth of the economic power of the Socialist world system and the strengthening of the economic system of each country.' Socialist economic integration, however, was to take place on the basis of 'complete voluntariness' and would not be linked with the creation of supra-national organs. There would be intensified co-operation in planning, with joint forecasts for energy, petrochemicals, and automative systems in the period 1971-75, and also in joint research projects in science and technology.

The program further provided for a new form of trading, 1.e., trade in non-quota goods which would not need to be balanced bilaterally but would, for clearing purposes, be counted in the total trade of the respective countries.

The 'transferable rouble' (the collective currency used for accounting in the internal Comecon clearing accounts but not transferable otherwise) was to be strengthened so as to attain 'real transferability' and be used in clearings with non-Comecon countries, and new parities would be established between the currencies of the member-States' and in relation to the 'transferable ruble.'

The proposed increased co-operation was to include the creation of a network of express trains and of long-distance roads, joint shipping enterprises, and the introduction of standardized container transport systems.

"The negotiations on the 'Complex Program' during the Council's 25 th session in Bucharest, July 27-29, 1971, revealed 'serious controversy on questions of integration,' and, in particular, strong reservations on any surrender of a country's sovereignty to Comecon were expressed by Romania.

\section{"Scientific Co-operation"}

"The Eastern Joint Institute for Nuclear Research at Dubna (U.S.S.R.)"

"A preliminary agreement on the establishment of an Eastern Joint Institute for Nuclear Research, made on March 26, 1956, was implemented on July 12, 1956 . The members of the joint Institute are Albania, Bulgaria, Czechoslovakia, the German Democratic Republic, Hungary, North Korea, the Mongolian People's Republic, Poland, Romania, the Soviet Union, and the Democratic Republic of Vietnam. The People's Republic of China, 
formerly a member, withdrew its scientists in July 1966."

"On its inception the Joint Institute comprised the former Institute of Nuclear Problems and Electro-physical Laboratory of the Soviet Academy of Sciences. Its equipment included one synchrotron generating 10,000, 000,000 electron volts and another generating $680,000,000$ electron volts. Other sections of the Institute, which have come into operation since its establishment, are the Laboratory of High Energies, which began operating in 1957; the Laboratory of Neutron Physics, equipped with an experimental fast neutron pulse reactor (in operation since 1960); and a Laboratory of Nuclear Reactions equipped with a cyclotron for accelerating multicharged ions (also coming into operation in 1960). The Joint Institute also has a Computing Center and a Radiochemical Laboratory."

"The supreme authority of the Joint Institute is the Committee of Government Plenipotentiaries, the members of which are the heads of the atomic energy authorities of the member-countries. The Committee is responsible for policy and finance. The program of work is the responsibility of a Scientific Council, while the practical administration is carried out by a Management consisting of a Director, two Vice-Directors and an Administrative Manager."

\section{"Other Scientific Centers"}

"Agreements signed in Moscow on April 28, 1971, provided for the establishment of seven new scientific centers to study such matters as new chemical compounds, prevention of pollution, control of weeds and agricultural pests, automated systems for medical institutions, anticorrosion measures, research in biological physics, and uses of timber." 


\section{"ADMISSION OF CUBA".}

"At the Council's 26th session, held in Moscow July 10-12, 1972, Cuba was unanimously admitted as a full member of Comecon."

"In the communique issued at the end of the session, it was stated that from 1970 to 1971 the Comecon member-countries had increased their national income by 6.3 percent; their industrial output by 7.8 percent; their transactions in 'transferable rubles' by 11 percent; and their foreign trade by 8.3 percent, that with the rest of the world having risen by 8.5 percent."

\section{"INCREASING PARTICIPATION BY YUGOSLAVIA"}

"At the same time the Yugoslav Federal Prime Minister signed a protocol on the undertaking of joint projects between Comecon membercountries and Yugoslavia." 


\section{APPENDIX I}

BLOC TRADE WITH THE U.S.A. AND WESTERN ERUOPE AND EUROPEAN NEUTRAL STATES ${ }^{1}$

(Figures cited are in unadjusted then current millions of U. S. dollars.)

1947

1948

1949

1950

1951

1952

1953

1954
908.1

1347.6

1281.8

1039.3

1243.1

1120.2

1005.2

1183.7

${ }^{1}$ Spulber, p. 463. 


\section{APPENDIX J}

GENERAL BLOC TRADING PATTERNS, 1937-1952 1

(Figures cited are in percentages of a given state's total foreign trade.)

- WITH THE SOVIET UNION -

\begin{tabular}{lccc} 
& 1937 & 1948 & 1952 \\
Czechoslovakia & 1 & 16 & 35 \\
Poland & 1 & 22 & 32 \\
Hungary & - & 11 & 29 \\
Rumania & 1 & 25 & 58 \\
Bulgaria & - & 54 & 57 \\
\hline
\end{tabular}

- WITH OTHER BLOC STATES -

Czechos lovakia

Poland

Hungary

Rumania

Bulgaria
10

6

13

17

12
14

12

23

46

20

32 
APPENDIX J (continued)

- WITH. THE SOVIET UNION AND OTHER BLOC STATES -

$1937 \quad 1948 \quad 1952$

Czechoslovakia

11

30

71

Poland

7

34

67

Hungary

13

34

71

Rumania

18

71

85

Bulgaria

12

74

89

- WITH THE REST OF THE WORLD -

1937

1948

1952

Czechoslovakia

89

70

29

Poland

93

66

33

Hungary

87

66

29

Rumania

82

29

15

Bulgaria

88

26

11 
TREATY OF FRIENDSHIP, COLLABORATION AND MUTUAI ASSISTANCE BETWEEN THE RUMANIAN PEOPLE'S REPUBLIC AND THE SOVIET UNION, MOSCOW, 4 FEBRUARY $1948^{1}$

[A treaty in similar terms was concluded between Bulgaria and the Soviet Union, 18 March 1948; and between Hungary and the Soviet Union, 18 February 1948.]

"The Praesidium of the Rumanian Popular Republic and the Praesidium of the Supreme Soviet of the Union of Soviet Socialist Republics,

"Desirous of consolidating friendly relations between Rumania and the Soviet Union;

"Desirous of keeping-up close collaboration, with a view to consolidating peace and general security, in accordance with the purposes and principles of the United Nations Organization;

"Convinced that the keeping up of friendship and good neighbourliness between Rumania and the Soviet Union is in accordance with the vital interests of the peoples of both States, and will bring the best possible contribution to their economic development;

"Have decided to conclude this Treaty, and have to that end full powers:

"Article 1. The High Contracting Parties undertake to take jointly all

$1_{\text {United Nations, Treaty Series, Treaties and International Agree- }}$ ments Registered or Filed and Reported with the Secretariat of the United Nations, vol. 48, "Treaty of Friendship, Collaboration and Mutual Assistance Between the Rumanian. People's Republic and the Soviet Union, Moxcow, 4 February 1948," pp. 189ff,, in Grenville, p. 364. Enclosed in brackets are Grenville's annotations. 
measures in their power to remove any threat of repeated aggression on the part of Germany, or of any State allying itself with Germany directly or in any other way."

"The High Contracting Parties state that it is their intention to participate with full sincerity in any international action aimed at ensuring the peace and security of nations, and that they will fully contribute to the carrying out of these great tasks."

"Article 2. Should one of the High Contracting Parties be involved in armed conflict with Germany, attempting to renew her policy of aggression, or with any other State allying itself with Germany, directly or in any other way, in her aggressive policy, the'other High Contracting Party will lose no time in giving the High Contracting Party involved in a conflict military or other aid with all the means at its disposal."

"This Treaty will be applied in accordance with the principles of the United Nations Charter."

"Article 3. Each of the High Contracting Parties undertakes to conclude no alliance and to participate in no coalition, action or measures directed against the other High Contracting Party."

"Article 4. The High Contracting Parties will consult with regard to all important international issues concerning the interests of the two countries."

"Article 5. The High Contracting Parties state that they will act in a spirit of friendship and collaboration, with a view to further developing and strengthening economic and cultural relations between the two States, with due regard for the principles of mutual respect for their 
independence and sovereignty, and of non-interference in the internal affairs of the other State."

"Article 6. This Treaty will remain in force for twenty years, as from the date of its signing. If, one year before the expiry of the twenty years, none of the High Contracting Parties expresses the wish to cancel the Treaty, it will remain in force another five years, and so on, until one of the High Contracting Parties, one year before the expiry of the current five-year period, announces in writing its intention to put an end to the validity of the Treaty ...." 


\section{APPENDIX L}

PERCENTAGE INCREASES IN INDUSTRIAL OUTPUT, 1951-19551

\begin{tabular}{lccccc}
\hline & (Previous year's output = 100.) & \\
\hline & 1951 & 1952 & 1953 & 1954 & 1955 \\
& 119 & 118 & 112 & 109 & 110 \\
Bulgaria & 115 & 118 & 110 & 104 & 111 \\
Czechoslovakia & 122 & 116 & 112 & 110 & 108 \\
East Germany & 130 & 124 & 111 & 103 & 108 \\
Hungary & 124 & 120 & 118 & 111 & 111 \\
Poland & 129 & 123 & 114 & 117 & 114 \\
Rumania & 124
\end{tabular}

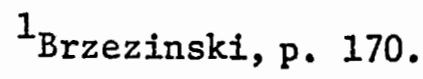


TREATY OF FRIENDSHIP, COOPERATION AND MUTUAL ASSISTANCE

BETWEEN ALBANIA, BULGARIA, HUNGARY, THE GERMAN DEMOCRATIC

REPUBLIC, POLAND, RUMANIA, THE SOVIET UNION AND CZECHOSLOVAKIA [WARSAW PACT], WARSAW, 14 MAY 19551

"The Contracting Parties,"

"Reaffirming their desire to create a system of collective security in Europe based on the participation of all European States, irrespective of their social and political structure, whereby the said States may be enabled to combine their efforts in the interests of ensuring peace in Europe;"

"Taking into consideration, at the same time, the situation that has come about in Europe as a result of the ratification of the Paris Agreements, which provide for the constitution of a new military group in the form of a 'West European Union,' with the participation of a remilitarized West Germany and its inclusion in the North Atlantic bloc, thereby increasing the danger of a new war and creating a threat to the national security of peace-loving States;"

"Being convinced that in these circumstances the peace-loving States. of Europe must take the necessary steps to safeguard their security and to promote the maintenance of peace in Europe;"

"Being guided by the purposes and principles of the Charter of the

$1_{\text {United Nations, Treaty Series, Treaties and Intermational Agreements }}$ Registered or Filed and Reported with the Secretariat of the United Nations, vol. 219, "Treaty of Friendship, Cooperation and Mutual Assistance Between Albania, Bulgaria, Hungary, The German Democratic Republic, Poland, Rumania, The Soviet Union, and Czechoslovakia [Warsaw Pact] Warsaw, 14 May 1955," pp. 3ff., in Grenville, pp. 365-367. Enclosed in brackets are Grenville's annotations. 
United Nations;"

"In the interests of the further strengthening and development of friendship, cooperation and mutual assistance in accordance with the principles of respect for the independence and sovereignty of States and of non-intervention in their domestic affairs;"

"Have resolved to conclude the present Treaty of Friendship, Cooperation and Mutual Assistance and have appointed as their plenipotentiaries ... who have agreed as follows:"

"Article 1. The Contracting Parties undertake, in accordance with the Charter of the United Nations, to refrain in their international relations from the threat or use of force and to settle their international disputes by peaceful means in such a manner that international peace and security are not endangered."

"Article 2. The Contracting Parties declare that they are prepared to participate, in a spirit of sincere cooperation, in all international action for ensuring international peace and security and will devote their full efforts to the realization of these aims."

"In this connection, the Contracting Parties shall endeavour to secure, in agreement with other States desiring to cooperate in this matter, the adoption of effective measures for the general reduction of armaments and the prohibition of atomic, hydrogen and other weapons of mass destruction."

"Article 3. The Contracting Parties shall consult together on all important international questions involving their common interests, with a view to strengthening international peace and security." 
"Whenever any one of the Contracting Parties considers that a threat of armed attack on one or more of the States parties to the Treaty has arisen, they shall consult together immediately with a view to providing for their joint defence and maintaining peace and security."

"Article 4. In the event of an armed attack in Europe on one or more of the States parties to the Treaty by any State or group of States, each State party to the Treaty shall, in the exercise of the right of individual or collective self-defence, in accordance with Article 51 of the United Nations Charter, afford the State or States so attacked immediate assistance, individually and in agreement with the other States parties to the Treaty, by all the means it considers necessary, including the use of armed force. The States parties to the Treaty shall consult together immediately concerning the joint measures necessary to restore and maintain international peace and security."

"Measures taken under this Article shall be reported to the Security Council in accordance with the provisions of the United Nations Charter. These measures shall be discontinued as soon as the Security Council takes the necessary action to restore and maintain international peace and security."

"Article 5. The Contracting Parties have agreed to establish a Unified Command, to which certain elements of their armed forces shall be allocated by agreement between the parties, and which shall act in accordance with jointly established principles. The parties shall likewise take such other concerted action as may be necessary to reinforce their defensive strength, in order to defend the peaceful labour of their peoples, 
guarantee the inviolability of their frontiers and territories and afford protection against possible aggression."

"Article 6. For the purpose of carrying out the consultations provided for in the present Treaty between the States parties thereto, and for the consideration of matters arising in connection with the application of the present Treaty, a Political Consultative Committee shall be established, in which each State party to the Treaty shall be represented by a member of the Government or by some other specially appointed representative."

"The Committee may establish such auxiliary organs as may prove to be necessary."

"Article 7. The Contracting Parties undertake not to participate in any coalitions or alliances, and not to conclude any agreements, the purposes of which are incompatible with the purposes of the present Treaty."

"The Contracting Parties declare that their obligations under international treaties at present in force are not incompatible with the provisions of the present Treaty."

"Article 8. The Contracting Parties declare that they will act in a spirit of friendship and cooperation to promote the further development and strengthening of the economic and cultural ties among them, in accordance with the principles of respect for each other's independence and sovereignty and of non-intervention in each other's domestic affairs."

"Article 9. The present Treaty shall be open for accession by other States, irrespective of their social and political structure, which 
express their readiness by participating in the present Treaty, to help in combining the efforts of the peace-loving States to ensure the peace and security of the peoples. Such accessions shall come into effect with the consent of the States parties to the Treaty after the instruments of accession have been deposited with the Government of the Polish People's Republic."

"Article 10. The present Treaty shall be subject to ratification, and the instruments of ratification shall be deposited with the Government of the Polish People's Republic."

"The Treaty shall come into force on the date of deposit of the last instrument of ratification. The Government of the Polish People's Republic shall inform the other States parties to the Treaty of the deposit of each instrument of ratification."

"Article 11. The present Treaty shall remain in force for twenty years. For Contracting Parties which do not, one year before the expiration of that term, give notice of termination of the Treaty to the Government of the Polish People's Republic, the Treaty shall remain in force for a further ten years."

"In the event of the establishment of a system of collective security in Europe and the conclusion for that purpose of a General European Treaty concerning collective security, a goal which the Contracting Parties shall steadfastly strive to achieve, the present Treaty shail cease to have effect as from the date on which the General European Treaty comes into force." 
"Done at Warsaw, this fourteenth day of May 1955, in one copy, in the Russian, Polish, Czech and German languages, all the texts being equally authentic. Certified copies of the present Treaty shall be transmitted by the Government of the Polish People's Republic to all the other parties to the Treaty." 
APPENDIX $N$

DECLARATION BY THE GOVERNMENT OF THE USSR ON THE PRINCIPLES OF DEVELOPMENT AND FURTHER STRENGTHENING OF FRIENDSHIP AND COOPERATION BETWEEN THE SOVIET UNION AND OTHER SOCIALIST STATES, OCTOBER $30,1956^{1}$

"A POLICE OF PEACEFUL coexistence, friendship, and cooperation among a 11 states has been and continues to be the firm foundation of the foreign relations of the Union of Soviet Socialist Republics."

"This policy finds its deepest and most consistent expression in the mutual relations among the socialist countries. United by the common ideals of building a socialist society and by the principles of proletarian internationalism, the countries of the great commonwealth of socialist nations can build their mutual relations only on the principles of complete equality, of respect for territorial integrity, state independence and sovereignty, and of noninterference in one another's internal affairs. Not only does this not exclude close fraternal cooperation and mutual aid among the countries of the socialist commonwealth in the economic, political, and cultural spheres; on the contrary, it presupposes these things."

I"Declaration by the Government of the USSR on the Principles of Development and Further Strengthening of Friendship and Cooperation Between the Soviet Union and Other Socialist States, October 30, 1956," Pravda, October 31, 1956, in Paul E. Zinner, ed., National Communism and Popular Revolt in Eastern Europe (New York: Columbia University Press, 1956), pp. 485-489. 
"The system of people's democracies took shape, grew strong and showed its great vital power in many countries of Europe and Asia on this foundation after the Second World War and the rout of fascism."

"In the process of the rise of the new system and the deep revolutionary changes in social relations, there have been many difficulties, unresolved problems, and downright mistakes, including mistakes in the mutual relations among the socialist countries--violations and errors which demeaned the principle of equality in relations among the socialist states."

"The 20th Congress of the Communist Party of the Soviet Union quite resolutely condemned these violations and mistakes, and set the task of consistent application by the Soviet Union of Leninist principles of equality of peoples in its relations with the other socialist countries. It proclaimed the need for taking full account of the historical past and peculiarities of each country that has taken the path of building a new life."

"The Soviet Government is consistently carrying out these historic decisions of the 20th Congress, which create conditions for further strengthening friendship and cooperation among the socialist countries on the firm foundation of observance of the full sovereignty of each socialist state."

"As recent events have demonstrated, it has become necessary to make this declaration of the Soviet Union's stand on the mutual relations of the USSR with other socialist countries, particularly in the economic and military spheres."

"The Soviet government is prepared to discuss together with the 
governments of other socialist states measures ensuring further development and strengthening of economic ties among the socialist countries in order to remove any possibility of violation of the principles of national sovereignty, mutual benefit, and equality in economic relations."

"This principle must also be extended to advisers. It is known that, in the first period of the formation of the new social system, the Soviet Union, at the request of the governments of the people's democracies, sent these countries a certain number of its specialists--engineers, agronomists, scientists, military advisers. In the recent period the Soviet Government has repeatedly raised before the socialist countries the question of recalling its advisers."

"In view of the fact that by this time the people's democracies have formed their own qualified national cadres in all spheres of economic and military affairs, the Soviet Government considers it urgent to review, together with the other socialist states, the question of the expediency of the further presence of USSR advisers in these countries."

"In the military domain an important basis of the mutual relations between the Soviet Union and the people's democracies is the Warsaw Treaty, under which its members adopted respective political and military obligations, including the obligation to take 'concerted measures necessary for strengthening their defense capacity in order to protect the peaceful labor of their peoples, to guarantee the inviolability of their borders and territory, and to ensure defense against possible aggression.'"

"It is known that Soviet units are in the Hungarian and Rumanian republics in accord with the Warsaw Treaty and governmental agreements. Soviet units are in the Polish republic on the basis of the Potsdam 
four-power agreement and the Warsaw Treaty. Soviet military units are not in the other people's democracies."

"For the purpose of assuring mutual security. of the socialist countries, the Soviet Government is prepared to review with the other socialist countries which are members of the Warsaw Treaty the question of Soviet troops stationed on the territory of the above-mentioned countries. In so doing the Soviet Government proceeds from the general principle that stationing the troops of one or another state which is a member of the Warsaw Treaty on the territory of another state which is a member of the treaty is done by agreement among all its members and only with the consent of the state on the territory of which and at the request of which these troops are stationed or it is planned to station them."

"The Soviet Government considers it necessary to make a statement in connection with the events in Hungary. The course of events has shown that the working people of Hungary, who have attained great progress on the basis of the people's democratic system, are rightfully raising the question of the need to eliminate serious defects in the sphere of economic construction, the question of further improving the living standards of the population, the question of combating bureaucratic distortions in the state machinery. However, this legitimate and progressive movement of the working people was soon joined by the forces of black reaction. and counterrevolution, which are trying to take advantage of the dissatisfaction of a part of the working people in order to undermine the foundations of the people's democratic system in Hungary and to restore the old landowner-capitalist ways in that country."

"The Soviet Government, like the whole Soviet people, deeply regrets that the development of events in Hungary has led to bloodshed." 
"At the request of the Hungarian people's govemment, the Soviet Government has granted consent to the entry into Budapest of Soviet military units to help the Hungarian people's army and the Hungarian agencies of government to bring order to the city."

"Having in mind that the further presence of Soviet military units in Hungary could serve as an excuse for further aggravation of the situation, the Soviet Government has given its military command instructions to withdraw the Soviet military units from the city of Budapest as soon as this is considered necessary by the Hungarian Government." .

"At the same time, the Soviet, Government is prepared to enter into the appropriate negotiations with the Government of the Hungarian People's Republic and other members of the Warsaw Treaty on the question of the presence of Soviet troops on the territory of Hungary."

"To guard the socialist achievements of people's democratic Hungary is the chief and sacred duty of the workers, peasants, intelligentsia, of all the Hungarian,working people at the present moment."

"The Soviet Government expresses confidence that the peoples of the socialist countries will not permit foreign and domestic reactionary forces to shake the foundations of the people's democratic system, a system established and strengthened by the self-sacrificing struggle and labor of the workers, peasants, and intelligentsia of each country. They will continue all efforts to remove all obstacles in the path of further strengthening the democratic foundations, independence, and sovereignty of their countries; to develop further the socialist foundations of each country, its economy and its culture, for the sake of an uninterrupted rise in the living standards and cultural level of all 
the working people; they will strengthen the fraternal unity and mutual aid of the socialist countries to buttress the great cause of peace and socialism. 


\section{APPENDIX 0}

THE REAFFIRMATION OF INTERNATIONAL COMMUNIST SOLIDARITY ${ }^{1}$

In November, 1957, a world-wide conference of Communist parties (excepting only Yugoslavia) was held in Moscow to repair the damage done to Communist discipline by de-Stalinization and the Polish and Hungarian revolutions. While some flexibility of tactics was admitted, the aim of Communist dictatorship was made clear, and unyielding doctrinal orthodoxy was demanded.

"The Communist and Workers' Parties taking part in this conference declare that the Leninist principle of peaceful coexistence of the two systems, which has been further developed in contemporary circumstances in the decisions of the 20th Party Congress, is the firm foundation of the foreign policy of the socialist countries and the reliable foundation of peace and friendship among the peoples. The five principles advanced jointly by the Chinese People's Republic and the Republic of India and the program adopted by the Bandung conference of African and Asian countries correspond to the interests of peaceful coexistence. The struggle for peace and peaceful coexistence have now become the demands of the broadest masses in all countries of the world."

"The Communist Parties regard the struggle for peace as their foremost task. Together with all peace-loving forces, they will do all in their power to prevent'war."

I"Declaration of the Conference of Representatives of Communist and Workers' Parties of Socialist Countries, Moscow, November, 1957," in The Current Digest of the Soviet Press 9 (January 1958): 4-7, in Robert V. Daniels, ed., A Documentary History of Communism, vo1. 2, pp. 270-273. 
"The conference considers that strengthening of the unity and fraternal cooperation of the socialist states and of the Communist and Workers' Parties of all countries and closing of the ranks of the international working class, national-liberation and democratic movements take on special importance in the present situation. ..."

"Intensification of the struggle against opportunist trends in the workers' and Communist movement is of great importance at the present stage. The conference stresses the necessity of resolutely overcoming revisionism and dogmatism in the ranks of the Communist and Workers' Parties. Revisionism and dogmatism in the workers' and Communist movement are today, as they have been in the past, of an international nature. Dogmatism and sectarianism hinder the development of Marxist-Leninist theory and its creative application in specific changing conditions, replace study of the specific situation with quotations and pedantry, and lead to the Party's isolation from the masses. A party that has locked itself up in sectarianism and that has lost contact with the broad masses can by no means bring victory to the cause of the working class." "In condemning dogmatism, the Communist Parties consider the main danger in present-day conditions to be revisionism or, in other words, right-wing opportunism, as a manifestation of bourgeois ideology that paralyzes the revolutionary energy of the working class and demands the preservation or restoration of capitalism. However, dogmatism and sectarianism can also be the main danger at different stages of development of one party or another. Each Communist Party determines what danger is the main danger to it at a given time. . . ."

"Present-day revisionism seeks to defame the great teaching of 
Marxism-Leninism, declares that it is 'obsolete' and that it has allegedly lost its importance for social development. The revisionists are trying to destroy the revolutionary soul of Marxism, to undermine the faith of the working class and the working people in socialism. They deny the historical necessity of a proletarian revolution and the dictatorship of , the proletariat during the period of transition from capitalism to socialism, deny the leading role of the Marxist-Leninist party, deny the principles of proletarian internationalism, demand abandonment of the Leninist principles of Party organization and, above all, of democratic centralism and demand that the Communist Party be transformed from a militant revolutionary organization into a kind of debating club."

"The entire experience of the international Communist movement teaches that resolute defense by the Communist and Workers' Parties of the Marxist-Leninist unity of their ranks and the banning of factions and groups that undermine its unity are a necessary guarantee of the successful accomplishment of the tasks of the socialist revolution and the building of socialism and communism. . . "

"The forms of the transition of different countries from capitalism to socialism may vary. The working class and its vanguard--the MarxistLeninist party--seek to bring about socialist revolution by peaceful means. Realization of this possibility would accord with the interests of the working class and of all the people and with the over-all national interests of the country."

"In present-day conditions in a number of capitalist countries the working class, headed by the vanguard, has the possibility--on the basis of a workers' and people's front or of other possible forms of agreement 
and political cooperation among the different parties and public organizations--to unite the majority of the people, win state power without civil war and ensure the transfer of the basic means of production to the hands of the people. Relying on the majority of the people and decisively rebuffing the opportunist elements incapable of relinquishing a policy of compromise with the capitalists and landlords, the working class can defeat the reactionary, antipopular forces, win a firm majority in parliament, transform the parliament from an instrument serving the class interests of the bourgeoisie into an instrument serving the working people, develop a broad mass struggle outside the parliament, break the resistance of the reactionary forces and create the necessary conditions for bringing about the socialist revolution peacefully. All this will be possible only by extensive, steady development of the class struggle of the workers, peasant masses and middle urban strata against big monopoly capital, against reaction, for profound social reforms, for peace and socialism."

"In conditions in which the exploiting classes resort to violence against the people, it is necessary to bear in mind another possibility-nonpeaceful transition to socialism. Leninism teaches and history confirms that the ruling classes never relinquish power voluntarily. In these conditions the severity and forms of the class struggle will depend not so much on the proletariat as on the resistance of the reactionary circles to the will of the overwhelming majority of the people, on the use of force by these circles at one or another stage of the struggle for socialism."

"In each country the real possibility of one or another means of 
transition to socialism depends on the specific historical conditions." "The Communist Parties stand for the establishment of cooperation with socialist parties both in the struggle for improving the working people's living conditions, for extending and preserving their democratic rights, for winning and defending national independence and for peace among peoples and in the struggle for winning power and building social-. ism. Although the right-wing leaders of the socialist parties are trying in every way to impede this cooperation, there are increasing opportunities for cooperation between the Communists and the socialists on many questions. The ideological differences, between the Communist and socialist parties should not keep them from establishing unity of action on the many current problems that today confront the workers' movement. . . " "The participants in the conference unanimously express their firm confidence that, by rallying their ranks and thereby rallying the working class and the peoples of all countries, the Communist and Workers' Parties vill undoubtedly surmount all obstacles on the path of progress and hasten great new victories for the cause of peace, democracy and socialism on a world scale." 


\section{APPENDIX $P$}

\section{STAGES OF COMECON ECONOMIC INTEGRATION ${ }^{1}$}

"In keeping with the objective process of internationalization of production, the Parties and Governments of the fraternal socialist countries are advancing along planned lines of socialist economic integration which represents the highest form of this process at the current stage. The interim results of the work already done in this direction were, as we know, summed up by the 29th Session of the Council for Mutual Economic Assistance (COMECON) held in Budapest in June 1975. The Session was attended by the Heads of Government of the member countries."

"The period between the 28th and 29th COMECON Sessions was marked by new successes in the member countries' internal and foreign policy and in further strengthening their friendship, unity and cohesion. Making optimal use of the advantages of socialist production and steadily expanding their economic, scientific and technological cooperation, these countries have secured considerable results in the fields of the economy, science and technology, and also in securing higher living standards for their working people. COMECON members are implementing the Comprehensive Program for Socialist Economic Integration; the countries concerned have signed agreements on the joint construction of large economic projects

$1_{\text {M. Lesechko, "Stages of COMECON Economic Integration," Kommunist }}$ No. 16 (1975), in Reprints from the Soviet Press 22 (January 1976): 45-55. 
in the fuel, raw-materials and power-generating industries, on speciallzation and cooperation in production and collective work on a number of scientific and technological problems."

"In summing up preliminary results in the coordination of their economic development plans for 1976-80, the Session took note of the tremendous work accomplished by the COMECON member countries and the bodies of the Council in this undertaking. They have now determined the main lines of economic, scientific and technical cooperation for the forthcoming five-year period and have reached agreement on the concrete measures necessary for their realization in the different sectors of the national economy. They have paved the way for the steady and dynamic growth of their combined production and for expansion of the economic potential of each separate country and of the entire community." "Coordination of economic development plans as the main method for the organization of cooperation and advancement of international socialist division of labor is becoming increasingly established as the basis for the agreed development of the economies of the fraternal countries. Plans for the new five-year period are being dove-tailed to accomplish the tasks laid down by the Comprehensive Program for Socialist Economic Integration."

"A distinguishing feature of the COMECON coordination today is that it has achieved a qualitatively higher level. In the past, it dealt mainly with the sphere of foreign (export-import) trade, determining the mutual deliveries of commodities. As a result, matters bearing on the advancement of production, specialization and cooperation, research, development and design, all of which logically precede and determine the 
delivery of goods, remained in the background. But now marked progress has been made in this respect."

"Coordination of the economic development plans for 1976-80 helped establish the necessary interconnections in cooperation in the spheres of production, science, technology, and economic planning. Businesslike contacts between the national planning agencies, broad participation in various forms of cooperation on the part of branch ministries and departments, of scientific research, design and other organizations, and of whole industries of the COMECON member countries have acquired special importance. Hundreds, even thousands of organizations and enterprises, and tens of thousands of various specialists are now directly participating in this extensive.process."

"In coordinating their plans, the parties concerned paid special attention to the extension of international specialization and cooperation in the field of machine-building. This has chiefly affected the production of tractors and other farm machinery, machines for light industry and the food industry, motor vehicles, and material handing equipment. The proposed specialization will make it possible to build separate industries of optimal size, cut down on small-quantity production and eliminate universalism. All this will improve economic performance. The accord reached has been consolidated by long-term bilateral and multilateral agreements, thus already forming the basis for considerable growth in reciprocal deliveries of plant and machinery."

"For instance, according to preliminary estimates, the overall volume of such deliveries between the USSR, on the one hand, and the other COMECON members and Yugoslavia, on the other, will in the 1976-80 period show a rise of nearly 75 percent over the level reached in the 
Ninth Five-Year Plan period. The Soviet Union is to expand considerably its export of power-generating equipment, motor vehicles (cars and trucks), tractors, other farm machinery, construction and road-building machines, mining equipment and other machinery. This will help the fratemal countries solve more successfully the serious problems confronting them in the field of power generation, metallurgy, chemical engineering and petrochemistry, radioelectronics, transport, farming and other sectors of their national economies."

"The COMECON countries will in turn considerably increase their deliveries of machinery and other equipment to the USSR on the basis of cooperation and specialization in production. These deliveries will be of increasingly comprehensive character, with a view to accelerating the development of the Soviet oil refining, petrochemical and chemical industries, light industry and the food industry. They will also meet the demand of the USSR in vessels and rolling stock."

"In coordinating their plans, the members of the socialist community looked thoroughly into the problem of providing themselves with fuel and raw materials. This is to be solved by the joint efforts of all the COMECON member countries, and is conditioned by the tremendous scope and high rate of their economic growth, as well as by their steadily rising demand for fuel and raw materials. A qualitatively new feature here has been the agreement reached on joint expansion of the output of their vital fuel and raw-materials industries in accordance with the Comprehensive Program."

"Such factors as strict adherence to the principles of internationalism and mutual assistance are helping the COMECON member countries provide their rapidly expanding economies with vital raw materials and fuels. 
As in the past, the Soviet Union will make a sizable contribution to this undertaking. It has already undertaken to considerably expand in the next five-year period its deliveries of oil and gas, iron ores, rolled steel and other commodities to the socialist countries to meet a large share of their demands."

"Proceeding from the preliminary results, it is now possible to conclude that in the forthcoming five-year period commodity exchange in trade between the COMECON countries will grow at high rates."

\section{"Long-Term Capital Investments"}

"Experience has shown that with the national economies of the socialist countries having grown to their present proportions, it will not be possible to solve all of the more complicated problems of production and economic growth in the course of a single five-year period. Implementation of many of the undertakings promoting the growth of material production calls for large capital investments and considerable time. That is why it is going to be necessary to extend joint work in planning for a longer period."

"Take the problem of fuel and energy supplies to the COMECON member countries. This is a problem facing the whole world economy. The socialist community has for some time now been solving it far more successfully than the capitalist world. In recent years the latter has been afflicted with another recurring crisis of overproduction, aggravated, moreover, not only by a monetary and credit crisis, but also by an unprecedented energy crisis."

"The COMECON countries have created a vast fuel and energy complex and their demands are being met in the main out of their own production 
facilities. Here the Soviet Union plays a leading role. It has been making every effort to increase deliveries and to create for its buyers favorable economic terms, despite the unsteady conditions of the world market. In 1975 the COMECON members will have received from the USSR close to 130 million tons of conditional fuel. In the next five years, it has been decided to boost these deliveries to about 800 million tons of conditional fuel. This will mark an increase of 43 percent over the level of deliveries in the 1971-75 period. About half of these deliveries will be oil and oil products."

"Forecasts show that the demand for energy after 1980 will skyrocket. Here it should be mentioned that the fuel resources in the socialist community are distributed unevenly. Moreover, the conditions for prospecting and extraction of minerals are becoming more and more difficult. Unless timely measures are taken, the production of raw materials will lag behind the demand. In particular, though on the whole the USSR has adequate fuel and raw-material resources, they are either scarce or altogether lacking in the European part of the country. Studies have shown that in the 1976-90 period the USSR will develop its fuel and to a great extent its raw-material industries mainly on the basis of the resources located in the eastern regions of the country. It should be noted that these territories are characterized by extremely harsh climatic and geographical conditions. As a result, the distance from the source of supply of raw materials to the consumers will increase by several thousand kilometers. This gives rise, among other things, to the problem of transportation, which now has acquired primary importance." "The above circumstances plus a steadily rising demand prompt the 
countries concerned to work out joint measures in advance in order to provide themselves in the future with fuel and raw materials. The COMECON bodies have been instructed to formulate concepts of long-term development of the fuel, energy and raw-materials base. They are to work on this together with the national organizations. Taking into account that to develop these industries much capital and time will be required, the 29 th Session made provisions for the drawing up of comprehensive 1ongterm, special-purpose programs of cooperation to fill the rational needs of the COMECON countries in the main types of energy as well as fuel and raw-materials resources. Moreover, it is important to find ways to secure considerable savings in energy resources and to limit the expansion of energy-consuming industries in regions lacking adequate sources of such energy. All this still remains an important scientific and technological problem. It will be necessary to pay special attention to the introduction of new equipment and advanced production processes and to the improvement of power-generating facilities."

"It will be essential for each country in the COMECON alliance intensively to increase its own production of mineral fuels. This refers above all to anthracite, brown coal, lignite and shale. There is reason to hope that it will be possible to increase the extraction of oil and gas from the continental shelf, i.e., from the seabed. There are still considerable untapped possibilities for more complete utilization of water power resources."

"In the field of power engineering, proper utilization of nuclear energy offers considerable promise. By the end of the 1970s it is proposed to build several large atomic power stations in the COMECON 
countries. This will be done with the technical assistance of the Soviet Union. In the subsequent period, many more atomic power stations will be built in these countries. The 29th Session instructed the COMECON bodies to draw up a broad program for the development of atomic technology on the basis of large-scale cooperation and specialization in production. The international economic association Interatomenergo is to play an important role in this. The countries which have founded it have good reason to expect vigorous activity from it and quick realization of the possibilities of socialist international division of labor."

"The 29th Session of COMECON also decided that a project for a General Grid for a United Electric Power System should be drawn up for those European COMECON members who are interested. When completed, this system will be a large-scale international undertaking and a new step in the advancement of socialist economic integration. The economic efficiency of the construction of electric power stations and transmission lines, as well as generation and consumption of electricity will increase. This in turn will improve the indicators characterizing the consumption of fuel and energy resources. The first element of the system will be a large 750-kilovolt power transmission line. Planned to go into operation in 1978, this line will be built on a multilateral basis."

"The reequipment of certain sectors of the national economy on the basis of the latest achievements in science and technology is a problem of equal importance and complexity. Obviously it will be impossible to solve it within a single five-year period."

"The 29th COMECON Session decided that a long-term comprehensive program for the development of machine-building on the basis of the most far-reaching specialization and cooperation in production should 
be drawn up. This program will enable the COMECON countries successfully to coordinate their efforts in meeting their needs in advanced equipment and reequipping the leading sectors of their national economies."

\section{"Agreed Plan for Multilateral \\ Integration Measures for 1976-80"}

"The 29th Session paid special attention to the discussion of the Agreed Plan for Multilateral Integration Measures for 1976-80, which is a vital outcome of the effort to coordinate the national plans. It reflects a qualitatively new stage in the advancement and improvement of economic cooperation. In actual fact this is the first collective document by sovereign socialist states to appear in the history of international relations, one which expresses their common will and combines their efforts in the solution of specific economic problems."

"The Agreed Plan covers measures for the construction of projects and additional capacities in the fuel and raw-materials industries, with investments to be made by the countries concerned. Among these are: the 2800-kilometer Orenburg-Western Frontier (of the USSR) main gas pipeline; the 860-kilometer 750-kilovolt Vinnitsa, West Ukraine (USSR)Albertirsa (Hungary) power transmission line; one of the world's largest pulp mills (in Ust-Ilim) with an annual production capacity of a halfmillion tons of high-quality pulp, and the Kiyembayevski asbestos mining plant."

"The joint efforts of the fraternal countries in the building of additional capacities for the production of nickel in the Republic of Cuba and the broad assistance rendered to Mongolia in the accelerated development of her national economy, in keeping with the Agreed Plan, 
are indicative of the genuinely internationalist character of cooperation between the COMECON member countries. An International Geological Expedition has been organized to assist Mongolia in the development of her natural wealth. It is intended to carry out a comprehensive geological prospecting program for numerous minerals. The COMECON countries will provide financial backing for this effort on a gratis basis." "The Agreed Plan has covered measures for specialization and cooperation in the manufacture of electronic computing equipment, machinery and other equipment for the oil and gas industries, material handling equipment, equipment and other facilities for the container transportation system, equipment for atomic power stations, etc. In the field of specialization and cooperation in production, special attention has been paid to item, unit and element manufacture as the most efficient form of division of labor with the most promising future. The Session also determined concrete ways to achieve specialization and cooperation in the production of many vital types of products turned out by the chemical engineering industry."

"The section dealing with scientific and technological problems forms a component part of the Agreed Plan of Multilateral Measures for Integration. It covers a range of vital economic problems, such as determining the most rational utilization of fuel and energy resources, combining efforts to solve problems in atomic power engineering, finding new methods for the production of proteins, raising the nutritive value of existing foodstuffs and developing new high-quality foods, developing methods for the comprehensive utilization of timber, measures for the inhibition of corrosion, and others. The pooling of scientific effort 
in the solution of these problems will help raise the general scientific and technical potential and the efficiency of research, and accelerate the assimilation of the latest scientific and technological achievements in production."

"It is obvious from the content, the character and principles governing the structure of the Agreed Plan that it is an important political and economic document of the COMECON member countries. It marks a new stage in their joint activity, which is characterized by a desire to take the fullest possible account of their mutual interests. The realization of the Plan will further strengthen the national economies of the fraternal countries along principles of socialist internationalism. At the same time it will considerably further the practical realization of the Comprehensive Program for Socialist Economic Integration."

\section{"Economic Potential of Socialist Community Steadily Rising as Result of Cooperation"}

"The advances already made in the promotion of socialist economic integration convincingly testify to the vitality of the Marxist-Leninist policy pursued by the ruling Communist and Workers' Parties in the COMECON countries. Thanks to their efforts, which are guided by the principles of proletarian socialist internationalism and directed toward the steady extension of cooperation and coordination of the activities of COMECON members, both in the sphere of foreign policy and in the field of the economy, the economic potential of each socialist country and of the entire community is steadily growing. At the same time the new community of countries united in the Council for Mutual Economic Assistance is 
becoming ever more attractive (as a trading partner) to the rest of the wor1d."

"In the period from 1950 to 1974, the overall national income of the COMECON member countries increased 520 percent, as compared to a growth of 190 percent in the countries of the European Economic Community and 180 percent in all the economically developed capitalist countries. During the same period, the industrial output of the COMECON countries increased by 820 percent, as compared to 240 percent in the economically developed capitalist countries."

"Those COMECON countries which were less developed in the past have now built up modern industries, including the most advanced industrial sectors. The economic levels of the countries belonging to the socialist community are being constantly raised. Their growing national incomes form the basis for the steadily rising living and cultural standards of their peoples. Production of consumer goods is being increased, with quality being improved and the choice widened. Housing construction is being conducted on a vast scale."

"The economic achievements and adherence to democratic principles in relations between the fraternal countries have also enhanced the international prestige of the Council for Mutual Economic Assistance. The Council has been granted the status of observer in the United Nations. The agreement on cooperation between COMECON and Finland is being put into practice. Not so long ago similar agreements were signed with Iraq and Mexico. Other countries and organizations have been showing serious interest in contacts with COMECON. The COMECON member countries have not only not set themselves the goal of isolating themselves from the rest of the world, they have been constantly working to establish 
equitable relations and to promote trade with third countries on the basis of mutual advantage, regardless of social and state systems. The fruitful results of the Conference on Security and Cooperation in Europe will, beyond doubt, open new, highly favorable prospects in this respect." "The 29th Session of the Council for Mutual Economic Assistance adopted important decisions which determine the patterns for the further advancement and extension of socialist economic integration. The results of the Session have been approved by the Central Committees of the Communist and Workers' Parties and by the Governments of the COMECON member countries."

"In their decision on the work of the 29th COMECON Session, the Politbureau of the Central Committee of the CPSU and the USSR Council of Ministers have expressed confidence in the fact that implementation of the measures it outlined would help to utilize additional possibilities for the solution of economic problems confronting the socialist countries, and to advance cooperation and socialist economic integration both in the forthcoming five-year period and in the longer term." 